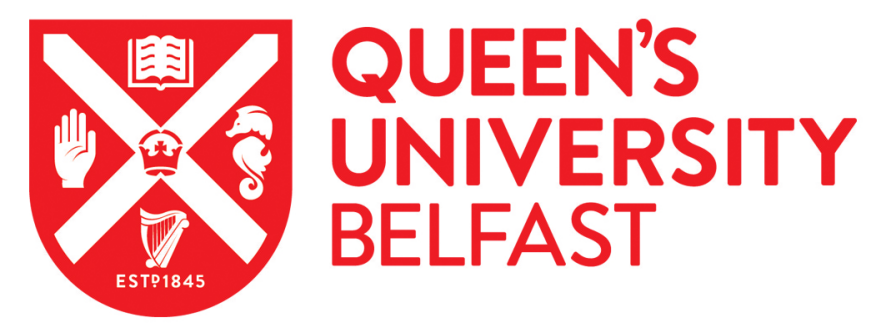

\title{
Quantitative Determination of C-C Coupling Mechanisms and Detailed Analyses on the Activity and Selectivity for Fischer-Tropsch Synthesis on Co(0001): Microkinetic Modeling with Coverage Effects
}

Yao, Z., Guo, C., Mao, Y., \& Hu, P. (2019). Quantitative Determination of C-C Coupling Mechanisms and Detailed Analyses on the Activity and Selectivity for Fischer-Tropsch Synthesis on Co(0001): Microkinetic Modeling with Coverage Effects. ACS Catalysis, 9, 5957-5973. https://doi.org/10.1021/acscatal.9b01150

Published in:

ACS Catalysis

Document Version:

Peer reviewed version

Queen's University Belfast - Research Portal:

Link to publication record in Queen's University Belfast Research Portal

\section{Publisher rights}

Copyright 219 American Chemical Society. This work is made available online in accordance with the publisher's policies. Please refer to any applicable terms of use of the publisher.

\section{General rights}

Copyright for the publications made accessible via the Queen's University Belfast Research Portal is retained by the author(s) and / or other copyright owners and it is a condition of accessing these publications that users recognise and abide by the legal requirements associated with these rights.

Take down policy

The Research Portal is Queen's institutional repository that provides access to Queen's research output. Every effort has been made to ensure that content in the Research Portal does not infringe any person's rights, or applicable UK laws. If you discover content in the

Research Portal that you believe breaches copyright or violates any law, please contact openaccess@qub.ac.uk. 


\title{
Quantitative Determination of C-C Coupling Mechanisms and
}

\author{
Detailed Analyses on the Activity and Selectivity for Fischer-
}

Tropsch Synthesis on Co(0001): Microkinetic Modelling with

\section{Coverage Effects}

\author{
Zihao Yao, Chenxi Guo, Yu Mao, and P. Hu* \\ School of Chemistry and Chemical Engineering, The Queen's University of Belfast, Belfast, \\ BT9 5AG, U.K.
}

\begin{abstract}
The Fischer-Tropsch synthesis plays a significant role in reforming natural resources to meet global demand for commodities, whilst there is ongoing oil depletion and population growth. Mechanisms have been long investigated, but it is still a heavily debated issue. In this work, all the possible elementary reaction steps on a flat cobalt surface were calculated using density functional theory (DFT) with van der Waals's interactions. Kinetic simulations using standard DFT data (free energies and barriers at low coverages), the so-called non-coverage dependent kinetic model commonly used in the literature, are compared to those from a coverage dependent kinetic model for the system. We show that the coverage dependent kinetic model gives rise to a TOF which is approximately six orders of magnitude larger than the TOF calculated using the non-coverage dependent kinetic model. Furthermore, it is found that $\operatorname{Co}(0001)$ is highly selective to olefin production, and it is very likely to produce long chain hydrocarbons. Both models demonstrate that the $\mathrm{CO}$ insertion mechanism is the dominant mechanism on $\mathrm{Co}(0001)$. Our calculations also reveal that high coverage of $\mathrm{CH}_{\mathrm{x}}$ leads to the carbide mechanism being significant and low coverage of $\mathrm{CH}_{\mathrm{x}}$ results in the $\mathrm{CO}$ insertion mechanism being more favored. Direct $\mathrm{CO}$ dissociation is difficult on $\mathrm{Co}(0001)$, which leads to monomers $\mathrm{CH}_{\mathrm{x}}$ being unable to occupy a certain amount of surface coverage making the carbide mechanism be inhibited. The reaction pathway through $\mathrm{CO}+\mathrm{H} \rightarrow \mathrm{CHO}, \mathrm{CHO}+\mathrm{H} \rightarrow \mathrm{CHOH}, \mathrm{CHOH} \rightarrow \mathrm{CH}+\mathrm{OH}$ is the main channel to form monomer $\mathrm{CH}$ based on the coverage dependent kinetic model simulations. The temperature affects considerably the surface coverage and the total reaction rate, leading to the
\end{abstract}


selectivity being highly temperature dependent. Our coverage dependent kinetic model predicts that the selectivity of oxygenates is high in comparison to methane in the low-temperature region from $425 \mathrm{~K}$ and $475 \mathrm{~K}$. From $475 \mathrm{~K}$ to $525 \mathrm{~K}$, the selectivity towards $\mathrm{CH}_{4}$ increases. From $525 \mathrm{~K}$ to $700 \mathrm{~K}$, the selectivity of $\mathrm{C}_{2}$ decreases significantly and the selectivity of $\mathrm{CH}_{4}$ increases remarkably.

KEYWORDS: Fischer-Tropsch Synthesis, DFT, Micro-kinetic modelling, Adsorbate-adsorbate interaction.

\section{INTRODUCTION}

The Fischer-Tropsch (FT) process $^{1-7}$ utilizes the earth's resources, namely coal, natural gas, and biomass, which can be converted into synthesis gas $\left(\mathrm{CO}+\mathrm{H}_{2}\right)$, to form hydrocarbons and oxygenated hydrocarbons. This process normally makes use of transition metal catalysts (mainly Fe and $\mathrm{Co}$ ). Cobalt based catalysts attract great attention mainly due to the reason that they have both high activity and good selectivity to form long chain hydrocarbons., ${ }^{5-13}$ The FT process involves the elementary steps of chain initiation, chain growth, and chain termination. The reaction systems include a large amount of possible elementary steps and reaction intermediates, leading to debates on the reaction mechanism. ${ }^{14-25}$

Three general mechanisms have been proposed since the 1920s; the carbide mechanism proposed by Fischer and Tropsch, ${ }^{2}$ the CO-insertion mechanism by Pichler and Schulz, ${ }^{26}$ and the hydroxy-carbene mechanism by Anderson and Emmett. ${ }^{27-28}$ For the carbide mechanism, Fischer and Tropsch believed that the chain growth mechanism was achieved via repeating $\mathrm{CH}_{2}$ couplings to form long chain hydrocarbons. ${ }^{2}$ Pichler and Schulz suggested that the chain growth was achieved via the $\mathrm{CO}$ insertion into adsorbed alkyl groups, which is the $\mathrm{CO}$ insertion mechanism. ${ }^{26}$ For the hydroxy-carbene mechanism, ${ }^{27-28}$ Anderson and Emmett proposed that the chain growth can be completed through dimerization between two $\mathrm{CH}_{2} \mathrm{OH}$ species. The mainstream opinion ${ }^{29-30}$ is that the carbide mechanism ${ }^{2,31-43}$ and the $\mathrm{CO}$ insertion mechanism ${ }^{26,44-45}$ are the most probable pathways. Despite tremendous efforts devoted to F-T reaction for nearly a century, the unified theory is still on the way. With the extensive DFT calculations, the deeper understanding on the mechanisms can be investigated on the atomic level. 
Outside the conventional three mechanisms, using DFT calculations $\mathrm{Li}$ and co-workers investigated $\mathrm{CHO}$ coupling to $\mathrm{CO}$ on $\mathrm{Rh}(111)$ and $\mathrm{Co}(0001)$, and found that the $\mathrm{CHO}$ insertion mechanism is competitive to the conventional carbide mechanism. ${ }^{46}$ Chen et al ${ }^{47}$ investigated the mechanism of $\mathrm{C}_{2}$ hydrocarbon formation on a fcc-Co(111) surface included carbide mechanism, $\mathrm{CO}$ insertion mechanism and $\mathrm{CHO}$ insertion mechanism, and it was believed that $\mathrm{CHO}$ insertion is more plausible for $\mathrm{C}-\mathrm{C}$ chain formation compared with $\mathrm{CO}$ insertion and $\mathrm{C}-\mathrm{C}$ coupling. It is clear that the fundamentals of forming long chain hydrocarbons on cobalt surfaces remain a contentious issue.

In the carbide mechanism, $\mathrm{CO}$ dissociates on the surface, and the carbon atoms are hydrogenated to yield $\mathrm{CH}_{\mathrm{x}}$ monomers which act as the chain initiators. The present monomers on the surface are sequentially inserted into hydrocarbon chains, and the chain termination is achieved by the desorption process of the produced olefin or paraffin.

For the CO-insertion mechanism, $\mathrm{CO}$ inserts into a hydrocarbon first; then after forming oxygenates, the $\mathrm{C}-\mathrm{O}$ bond breaks, and the process is repeated to form long chained hydrocarbons. Schweicher et al. provided some evidence to support $\mathrm{CO}$ insertion mechanism on $\mathrm{Co} / \mathrm{MgO}$ catalysts. ${ }^{48}$ The CO-insertion mechanism was investigated in the literature ${ }^{33,44-45,49}$ on the flat $\mathrm{Co}(0001)$ surface. From the PM-PAIR signal indicate that chain-growth is taking place on the defect sites, whereas the terrace sites act as a source for CO-monomers. ${ }^{50}$ It was found experimentally that the TOF of FT synthesis is decreased if catalyst particle sizes are too small, and this was explained by the lack of terrace sites, and hydrocarbons strongly block the sites, leaving no room for the reservoir of CO-monomers, and consequently lowering the activity and selectivity. ${ }^{50}$ Yang et al. carried out microkinetic studies on the activity of $\operatorname{Rh}(111)$ and $\operatorname{Rh}(211)$ and investigated the selectivity for the methane, acetaldehyde, and ethanol and their results showed that the (111) surface is selective towards $\mathrm{C}_{2+}$ oxygenates and the (211) surface is selective towards methane..$^{51}$ It was suggested that the coupling of $\mathrm{CO}$ and $\mathrm{CH}$ was more favour on $\mathrm{Rh}(111)$ which is important to $\mathrm{CO}$ insertion mechanism.

The applications of microkinetic models combined with energy data calculated by DFT have achieved significant progress for the FT process..$^{51-57}$ A simple microkinetic model assumes that there are no interactions between adsorbates using the mean-field theory. However, for the high coverage system, the coverage effect becomes highly complex and cannot be ignored. Filot et al. ${ }^{53}$ pointed out that their computed rates are lower than experimental values, and they proposed two 
important reasons: (i) the chemisorption energies calculated by DFT are stronger (over-bonding); and (ii) their models did not include the coverage effect. The neglect of lateral interactions may cause large deviations between simulations and experiments. Understanding adsorbate-adsorbate interactions remains challenging for simulations. ${ }^{58-59}$ By investigating the reaction with the coverage effect, Nørskov and co-workers developed coverage dependent models for CO oxidation $^{60}$ and $\mathrm{CO}$ methanation ${ }^{61}$ on transition metal surfaces. A general method was used to describe the differential chemisorption energies which were reduced considerably after a threshold point. ${ }^{60-61}$

In this work, we investigate the FT reaction mechanisms on the flat cobalt surface using DFT calculations that include van der Waals interactions combined with non-coverage dependent and our coverage-dependent kinetic modelling for two reasons. Firstly, cobalt is an active catalyst for the FT synthesis and the flat surface is the simplest model of catalysts. Secondly, although some elementary reactions may take place on cobalt defects, the reaction sites on the flat surface are the most abundant sites, connecting the defects. To obtain the activity and selectivity from the flat surface will provide insight into the cobalt system and give rise to the reference for other surfaces. It is, therefore, certainly the starting point to understand the cobalt system. The degree of rate control analysis ${ }^{62-65}$ is used to investigate elementary steps that control $\mathrm{CO}$ consumption rate and the product selectivity and to study how these steps change with reaction temperature from $425 \mathrm{~K}$ to $700 \mathrm{~K}$. In this work, we only focused attention on hydrocarbon formation up to $\mathrm{C}_{2}$ species. We aim to answer the following questions: (i) What is the chain growth mechanism on the flat cobalt? (ii) What influences the activity and selectivity on the cobalt surface if we consider the coverage effect? (iii) How temperature affects the activity and selectivity on the cobalt surface?

\section{MODELS AND COMPUTATIONAL METHODS}

\subsection{Surface Model}

To study FT reactions on the Co(0001) surface, a periodic four-layer surface (Figure 1) was utilized in the calculations. The bottom two layers of metal atoms were fixed, and the top two layers are

relaxed with a $15 \AA$ vacuum region. The thickness of the slab was verified to be sufficient. Due to the magnetic properties of cobalt, the spin polarized effect was considered in our calculations. Our calculation on $\operatorname{Co}(0001)$ yielded a moment of $1.64 \mu_{b}$, being close to the value of $1.63 \mu_{b}$ on $\alpha$-Co 
in the literature. ${ }^{66}$ The calculated lattice constant ratio b/a was 1.617 , which was close to the experimental value 1.623 .
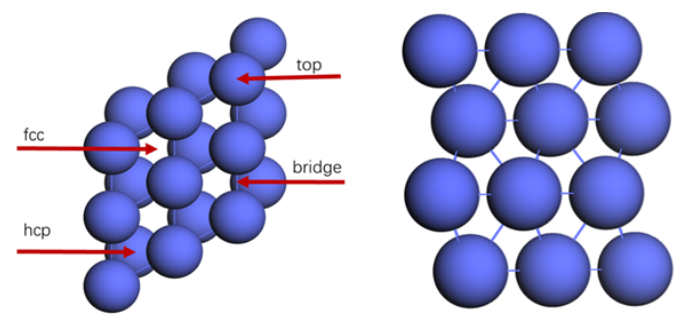

Figure 1. The top view (left) and side view (right) of the flat cobalt surface. The red arrows are pointed at different adsorption sites, namely hcp, fcc, top and bridge.

\subsection{Computational Methods}

DFT calculations were carried out for the Fischer-Tropsch reaction within the framework of generalized gradient approximation (GGA) with the Perdew-Burke-Ernzerhof (PBE) ${ }^{67}$ functional in the Vienna ab initio simulation program (VASP). ${ }^{68-69}$ The projector-augmented-wave (PAW) ${ }^{70-}$ ${ }^{71}$ pseudopotentials were used, and the cut-off energy of plane-wave basis expansion was set to $400 \mathrm{eV}$. The $\mathrm{p}(3 \mathrm{x} 3)$ unit cell was utilized and k-point sampling parameters were tested using $\mathrm{CO}$ chemisorption energy with $1 \times 1 \times 1,2 \times 2 \times 1,3 \times 3 \times 1$ and $4 \times 4 \times 1$. The chemisorption energies were converged from $2 \times 2 \times 1$, and the errors were below $0.1 \mathrm{eV}$. Based on the tests, a $3 \times 3 \times 1$ Monkhorst pack k-point mesh sampling was used for all the calculations. Spin polarized calculations were included to account for the magnetic properties of cobalt. The effect of van der Waals's interactions is important for the hydrocarbon intermediates on the surface..$^{72}$ Therefore, the DFT-D3 method ${ }^{73-}$ ${ }^{74}$ was utilized to calculate all the intermediates and transition states. The ionic degrees of freedom were relaxed using the BFGS minimization scheme until the Hellman-Feynman forces on each ion were less than $0.05 \mathrm{eV} / \AA$. The transition states (TSs) were searched using the method called a constrained optimization scheme. ${ }^{75-77}$ The transition states were confirmed by two rules: (i) all forces on atoms have been optimized to be less than $0.05 \mathrm{eV} / \AA$; (ii) the total energy is a maximum along the reaction coordinate but a minimum with respect to all other degrees of freedom.

Vibrational frequency analyses were performed to confirm the integrity of initial states, transition states and final states. The zero-point energy (ZPE) correction was calculated as follows: 
$\mathrm{ZPE}=\sum_{\mathrm{i}} \frac{\mathrm{h} v_{\mathrm{i}}}{2}$

where $\mathrm{h}$ is Planck's constant and the standard molar vibrational internal energy contribution is calculated as follows:

$\mathrm{U}_{\mathrm{vib}}^{\mathrm{o}}=\mathrm{RT} \sum_{\mathrm{i}} \frac{\mathrm{h} v_{\mathrm{i}} / \mathrm{K}_{\mathrm{B}}}{\mathrm{e}^{\mathrm{hv_{ \textrm {i } }} / \mathrm{K}_{\mathrm{B}} \mathrm{T}}-1}$

where $\mathrm{K}_{\mathrm{B}}$ is the Boltzmann constant and $\mathrm{R}$ is the gas constant. The standard molar vibrational entropy is given by:

$S_{\text {vib }}^{O}=R \sum_{i}\left[\frac{\frac{h v_{i}}{K_{B} T}}{e^{\frac{h_{i}}{K_{B} T}}-1}-\ln \left(1-e^{-h v_{i} / K_{B} T}\right)\right]$

Overall, adding the free energy corrections together, the standard molar Gibbs free energy change for the elementary reaction for the FT reaction can be written as follow:

$\Delta \mathrm{G}^{0}=\Delta \mathrm{E}+\Delta \mathrm{ZPE}+\gamma \mathrm{RT}\left(1+\ln \frac{\mathrm{P}}{\mathrm{P}_{0}}\right)+\Delta \mathrm{U}^{0}-\mathrm{T} \Delta \mathrm{S}^{0}$

where $\Delta \mathrm{E}$ represents the difference of the total energies from the VASP calculation. If it is gaseous molecule, then 1 is chosen as the value of $\gamma$ and 0 is selected for $\gamma$ for surface reactant and $\mathrm{P}$ is the partial pressure.

The free-energy corrections for molecules in the gas phase were calculated using the Gaussian 09 package, ${ }^{78}$ and the basis set was B3LYP/6-311g. ${ }^{99-80}$

\subsection{The Choice of Elementary Steps}

To understand the FT synthesis, we investigated all the possible reaction pathways we can think of on $\mathrm{Co}(0001)$, corresponding to the formation of hydrocarbons $\left(\mathrm{CH}_{4}, \mathrm{CH}_{2} \mathrm{CH}_{2}, \mathrm{CH}_{3} \mathrm{CH}_{3}\right)$ and oxygenate $\left(\mathrm{CH}_{3} \mathrm{OH}\right)$. The reaction pathways were classified as follows: (1) Direct $\mathrm{CO}$ dissociation and $\mathrm{H}$-assisted $\mathrm{CO}$ dissociation; (2) water formation; (3) $\mathrm{C}_{1}$ hydrogenation to methane; (4) $\mathrm{C}_{1}+\mathrm{C}_{1}$ coupling reactions; (5) $C_{2}$ hydrogenation reactions; (6) $C O$ and $C_{1}$ coupling reactions; (7) $C_{1}$ and $\mathrm{OH}$ coupling reactions; (8) $\mathrm{CH}_{\mathrm{x}} \mathrm{CH}_{\mathrm{y}} \mathrm{O}$ hydrogenations; (9) $\mathrm{CH}_{\mathrm{x}} \mathrm{CH}_{\mathrm{y}} \mathrm{O}$ dissociation; and (10) $\mathrm{C}_{1}$ and CHO coupling reactions. The elementary steps are shown in Table 1 . The geometry and energy data are presented in the Supporting Information. 
Table 1. Elementary steps for FT reactions on $\operatorname{Co}(0001)$.

\begin{tabular}{|c|c|}
\hline \multicolumn{2}{|c|}{ Elementary reaction steps } \\
\hline (R1) $\mathrm{CO}+* \rightleftarrows \mathrm{CO}^{*}$ & 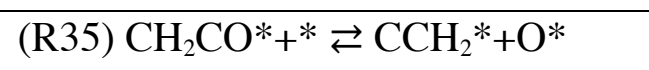 \\
\hline (R2) $\mathrm{H}_{2}+^{*}+^{*} \rightleftarrows \mathrm{H}^{*}+\mathrm{H}^{*}$ & (R36) $\mathrm{CH}_{3} \mathrm{CO}^{*}+* \rightleftarrows \mathrm{CCH}_{3}{ }^{*}+\mathrm{O}^{*}$ \\
\hline (R3) $\mathrm{CO}^{*}+* \rightleftarrows \mathrm{C}^{*}+\mathrm{O}^{*}$ & (R37) $\mathrm{CHCHO}^{*}+* \rightleftarrows \mathrm{CHCH}^{*}+\mathrm{O}^{*}$ \\
\hline (R4) $\mathrm{O}^{*}+\mathrm{H}^{*} \rightleftarrows \mathrm{OH}^{*}+*$ & (R38) $\mathrm{CH}_{2} \mathrm{CHO}^{*}+* \rightleftarrows \mathrm{CHCH}_{2}{ }^{*}+\mathrm{O}^{*}$ \\
\hline (R5) $\mathrm{OH}^{*}+\mathrm{H}^{*} \rightleftarrows \mathrm{H}_{2} \mathrm{O}+*+*$ & (R39) $\mathrm{CH}_{2} \mathrm{OH}^{*}+\mathrm{H}^{*} \rightleftarrows \mathrm{CH}_{3} \mathrm{OH}+*+^{*}$ \\
\hline (R6) $\mathrm{OH}^{*}+\mathrm{OH}^{*} \rightleftarrows \mathrm{H}_{2} \mathrm{O}+\mathrm{O}^{*}+*$ & (R40) $\mathrm{COH}^{*}+\mathrm{H}^{*} \rightleftarrows \mathrm{CHOH}^{*}+*$ \\
\hline (R7) $\mathrm{H}^{*}+\mathrm{C}^{*} \rightleftarrows \mathrm{CH}^{*}+*$ & (R41) $\mathrm{CHOH}^{*}+\mathrm{H}^{*} \rightleftarrows \mathrm{CH}_{2} \mathrm{OH}^{*}+^{*}$ \\
\hline (R8) $\mathrm{H}^{*}+\mathrm{CH}^{*} \rightleftarrows \mathrm{CH}_{2}{ }^{*}+^{*}$ & $(\mathrm{R} 42) \mathrm{CH}_{3} *+\mathrm{OH}^{*} \rightleftarrows \mathrm{CH}_{3} \mathrm{OH}+*+^{*}$ \\
\hline (R9) $\mathrm{H}^{*}+\mathrm{CH}_{2} * \underset{\mathrm{CH}_{3}}{*}+^{*}$ & (R43) $\mathrm{C}^{*}+\mathrm{C}^{*} \rightleftarrows \mathrm{CC}^{*}+^{*}$ \\
\hline (R10) $\mathrm{H}^{*}+\mathrm{CH}_{3}{ }^{*} \rightleftarrows \mathrm{CH}_{4}+^{*}+^{*}$ & (R44) $\mathrm{C}^{*}+\mathrm{CH}^{*} \rightleftarrows \mathrm{CCH}^{*}+^{*}$ \\
\hline (R11) $\mathrm{CO}^{*}+\mathrm{H}^{*} \rightleftarrows \mathrm{COH}^{*}+^{*}$ & (R45) $\mathrm{C}^{*}+\mathrm{CH}_{2} * \rightleftarrows \mathrm{CCH}_{2}{ }^{*} *$ \\
\hline (R12) $\mathrm{CO}^{*}+\mathrm{H}^{*} \rightleftarrows \mathrm{CHO}^{*}+*$ & (R46) $\mathrm{C}^{*}+\mathrm{CH}_{3} * \rightleftarrows \mathrm{CCH}_{3}{ }^{*}+*$ \\
\hline (R13) $\mathrm{COH}^{*}+* \rightleftarrows \mathrm{C}^{*}+\mathrm{OH}^{*}$ & (R47) $\mathrm{CH}^{*}+\mathrm{CH}^{*} \rightleftarrows \mathrm{CHCH}^{*}+*$ \\
\hline (R14) $\mathrm{CHO}^{*}+* \rightleftarrows \mathrm{CH}^{*}+\mathrm{O}^{*}$ & $(\mathrm{R} 48) \mathrm{CH}^{*}+\mathrm{CH}_{2}{ }^{*} \rightleftarrows \mathrm{CHCH}_{2}{ }^{*}{ }^{*}$ \\
\hline (R15) $\mathrm{CHO}^{*}+\mathrm{H}^{*} \rightleftarrows \mathrm{CHOH}^{*}+*$ & (R49) $\mathrm{CH}^{*}+\mathrm{CH}_{3} * \rightleftarrows \mathrm{CHCH}_{3}{ }^{*}+*$ \\
\hline (R16) $\mathrm{CHOH}^{*}+* \rightleftarrows \mathrm{CH}^{*}+\mathrm{OH}^{*}$ & (R50) $\mathrm{CH}_{2}{ }^{*}+\mathrm{CH}_{2} * \rightleftarrows \mathrm{CH}_{2} \mathrm{CH}_{2}{ }^{*}+*$ \\
\hline (R17) $\mathrm{CHO}^{*}+\mathrm{H}^{*} \rightleftarrows \mathrm{CH}_{2} \mathrm{O}^{*}+^{*}$ & (R51) $\mathrm{CH}_{2}{ }^{*}+\mathrm{CH}_{3}{ }^{*} \rightleftarrows \mathrm{CH}_{2} \mathrm{CH}_{3}{ }^{*}+*$ \\
\hline (R18) $\mathrm{CH}_{2} \mathrm{O}^{*}+* \rightleftarrows \mathrm{CH}_{2} *+\mathrm{O}^{*}$ & (R52) $\mathrm{CC}^{*}+\mathrm{H}^{*} \rightleftarrows \mathrm{CCH}^{*}+*$ \\
\hline (R19) $\mathrm{CH}_{2} \mathrm{O}^{*}+\mathrm{H}^{*} \rightleftarrows \mathrm{CH}_{2} \mathrm{OH}^{*}+*$ & (R53) $\mathrm{CCH}^{*}+\mathrm{H}^{*} \rightleftarrows \mathrm{CCH}_{2}{ }^{*}{ }^{*}$ \\
\hline (R20) $\mathrm{CH}_{2} \mathrm{OH}^{*}+* \rightleftarrows \mathrm{CH}_{2}{ }^{*}+\mathrm{OH}^{*}$ & (R54) $\mathrm{CCH}^{*}+\mathrm{H}^{*} \rightleftarrows \mathrm{CHCH}^{*}+*$ \\
\hline (R21) $\mathrm{CH}_{2} \mathrm{O}^{*}+\mathrm{H}^{*} \rightleftarrows \mathrm{CH}_{3} \mathrm{O}^{*}+^{*}$ & (R55) $\mathrm{CCH}_{2} *+\mathrm{H}^{*} \rightleftarrows \mathrm{CCH}_{3}{ }^{*}{ }^{*}$ \\
\hline (R22) $\mathrm{CH}_{3} \mathrm{O}^{*}+* \rightleftarrows \mathrm{CH}_{3}{ }^{*}+\mathrm{O}^{*}$ & (R56) $\mathrm{CCH}_{2}{ }^{*}+\mathrm{H}^{*} \rightleftarrows \mathrm{CHCH}_{2}{ }^{*}{ }^{*}$ \\
\hline (R23) $\mathrm{CH}_{3} \mathrm{O}^{*}+\mathrm{H}^{*} \rightleftarrows \mathrm{CH}_{3} \mathrm{OH}+^{*}+*$ & (R57) $\mathrm{CCH}_{3}{ }^{*}+\mathrm{H}^{*} \rightleftarrows \mathrm{CHCH}_{3}{ }^{*}{ }^{*}$ \\
\hline (R24) $\mathrm{CH}^{*}+\mathrm{CO}^{*} \rightleftarrows \mathrm{CHCO}^{*}+*$ & (R58) $\mathrm{CH}_{2} \mathrm{CH}_{2} *+\mathrm{H}^{*} \rightleftarrows \mathrm{CH}_{2} \mathrm{CH}_{3} *+^{*}$ \\
\hline (R25) $\mathrm{CH}_{2} *+\mathrm{CO}^{*} \rightleftarrows \mathrm{CH}_{2} \mathrm{CO}^{*}+*$ & (R59) $\mathrm{CH}_{2} \mathrm{CH}_{3} *+\mathrm{H}^{*} \rightleftarrows \mathrm{CH}_{3} \mathrm{CH}_{3}+^{*}+^{*}$ \\
\hline (R26) $\mathrm{CH}_{3}{ }^{*}+\mathrm{CO}^{*} \rightleftarrows \mathrm{CH}_{3} \mathrm{CO}^{*}+*$ & (R60) $\mathrm{CHCH}^{*}+\mathrm{H}^{*} \rightleftarrows \mathrm{CHCH}_{2}{ }^{*}{ }^{*}$ \\
\hline$(\mathrm{R} 27) \mathrm{CH}^{*}+\mathrm{CHO}^{*} \rightleftarrows \mathrm{CHCHO}^{*}+*$ & (R61) $\mathrm{CHCH}_{2}{ }^{*}+\mathrm{H}^{*} \rightleftarrows \mathrm{CH}_{2} \mathrm{CH}_{2}{ }^{*}{ }^{*}$ \\
\hline
\end{tabular}




\begin{tabular}{|c|c|}
\hline (R28) $\mathrm{CH}_{2}{ }^{*}+\mathrm{CHO}^{*} \rightleftarrows \mathrm{CH}_{2} \mathrm{CHO}^{*}+*$ & (R62) $\mathrm{CHCH}_{2}{ }^{*}+\mathrm{H}^{*} \rightleftarrows \mathrm{CHCH}_{3}{ }^{*}{ }^{*}$ \\
\hline (R29) $\mathrm{CHCO}^{*}+\mathrm{H}^{*} \rightleftarrows \mathrm{CH}_{2} \mathrm{CO}^{*}+*$ & (R63) $\mathrm{CHCH}_{3}{ }^{*}+\mathrm{H}^{*} \rightleftarrows \mathrm{CH}_{2} \mathrm{CH}_{3}{ }^{*}+*$ \\
\hline (R30) $\mathrm{CHCO}^{*}+\mathrm{H}^{*} \rightleftarrows \mathrm{CHCHO}^{*}+*$ & (R64) $\mathrm{CH}_{2} \mathrm{CH}_{2}{ }^{*} \rightleftarrows \mathrm{CH}_{2} \mathrm{CH}_{2}+^{*}$ \\
\hline (R31) $\mathrm{CH}_{2} \mathrm{CO}^{*}+\mathrm{H}^{*} \rightleftarrows \mathrm{CH}_{2} \mathrm{CHO}^{*}+*$ & (R65) $\mathrm{CH}_{2} \mathrm{CHO}^{*}+\mathrm{H}^{*} \rightleftarrows \mathrm{CH}_{3} \mathrm{CHO}^{*}+*$ \\
\hline (R32) $\mathrm{CH}_{2} \mathrm{CO}^{*}+\mathrm{H}^{*} \rightleftarrows \mathrm{CH}_{3} \mathrm{CO}^{*}+*$ & (R66) $\mathrm{CH}_{3} \mathrm{CHO}^{*}+* \rightleftarrows \mathrm{CHCH}_{3}{ }^{*}+\mathrm{O}^{*}$ \\
\hline (R33) $\mathrm{CHCHO}^{*}+\mathrm{H}^{*} \rightleftarrows \mathrm{CH}_{2} \mathrm{CHO}^{*}+*$ & (R67) $\mathrm{CH}_{3} \mathrm{CO}^{*}+\mathrm{H}^{*} \rightleftarrows \mathrm{CH}_{3} \mathrm{CHO}^{*}+*$ \\
\hline (R34) $\mathrm{CHCO}^{*}+*$ & \\
\hline
\end{tabular}

\subsection{Microkinetic Model}

\subsubsection{Non-coverage Dependent Kinetic Model}

To investigate mechanisms on $\mathrm{Co}(0001)$, the non-coverage dependent microkinetic model was used. The calculation flow diagram is displayed in Figure 2.

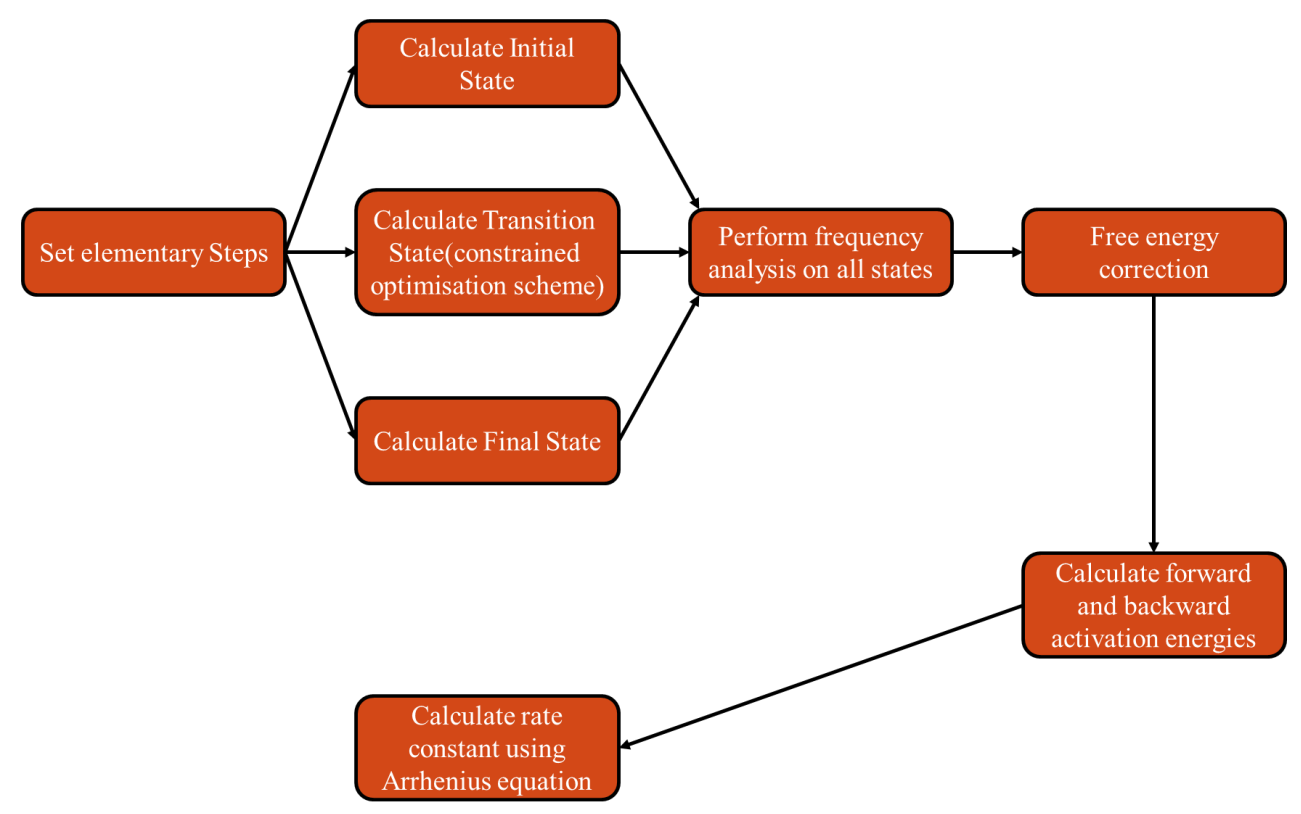

Figure 2. The calculated flow diagram for the basic settings of a microkinetic modelling.

The reaction elementary steps in Table 1 were chosen. $r_{i}$ is the individual reaction rate of step $i$. $\mathrm{k}_{\mathrm{f}}(\mathrm{i})$ and $\mathrm{k}_{\mathrm{r}}(\mathrm{i})$ are the forward rate constant and reverse rate constant, respectively. The rate constants were calculated using the transition state theory, which can be expressed as: 
$\mathrm{k}_{\mathrm{i}}=\frac{\mathrm{k}_{\mathrm{B}} \mathrm{T}}{\mathrm{h}} \mathrm{e}^{\frac{-\Delta \mathrm{G}_{\mathrm{i}} \neq 0}{\mathrm{k}_{\mathrm{B}} \mathrm{T}}}$

where $\mathrm{k}_{\mathrm{B}}$ is the Boltzmann constant, $\mathrm{T}$ is the temperature, $\mathrm{h}$ is the Planck's constant, $\Delta \mathrm{G}_{\mathrm{i}}{ }^{\neq 0}$ is the change of standard molar Gibbs free energies between the transition state and the initial state for step i from the DFT calculations.

In the microkinetic model simulations, the set of ordinary differential equations (ODEs) were solved. The ODEs were integrated over time until a steady state solution was reached, in which all the coverage change of surface intermediates equates to zero. Namely, it is given by:

$\frac{\mathrm{d} \theta_{\mathrm{i}}}{\mathrm{dt}}=\sum_{\mathrm{j}} v_{\mathrm{i}, \mathrm{j}} \mathrm{r}_{\mathrm{j}}=0$

where $\theta_{i}$ is the coverage of the intermediate $i$ and $v_{i, j}$ is the stoichiometric coefficient of intermediate at elementary step $\mathrm{j}$.

\subsubsection{Coverage-Dependent Kinetic Model}

The traditional mean field microkinetic model ignored the effect of coverage, and it may fail to describe the coverage on the surface. Based on the coverage effect prevailing in the real system, we developed our model and the core concept is described as follows: The chemisorption energy is strongly affected by the coverage. The total coverage was assumed to be 1 monolayer (ML). Based on the strong chemisorption energy of $\mathrm{CO}$, which was known to be the most abundant species on the surface, all the chemisorption energies of intermediates were calculated under a $\mathrm{CO}$ rich environment. The rational is that because $\mathrm{CO}$ is abundant and the coverages of other species are low, it is likely that any surface species would be surrounded by $\mathrm{CO}$ and the chemisorption energy of a surface species would be considerably affected by CO rather than any other species. The differential chemisorption energy for an adsorbate as a function of $\mathrm{CO}$ coverage takes the form:

$\mathrm{E}_{\mathrm{i}}\left(\theta_{\mathrm{i}}\right)=\mathrm{a}_{1} \theta_{\mathrm{i}}+\mathrm{b}_{1}$ when $\theta_{\mathrm{i}} \leq \theta_{0}$

$\mathrm{E}_{\mathrm{i}}\left(\theta_{\mathrm{i}}\right)=\mathrm{a}_{2} \theta_{\mathrm{i}}^{2}+\mathrm{b}_{2} \theta_{\mathrm{i}}+\mathrm{c}_{2}$ when $\theta_{\mathrm{i}}>\theta_{0}$

where $E_{i}\left(\theta_{i}\right)$ is the differential chemisorption energy of adsorbate $i$ at $C O$ coverage $\theta_{i}$.

On the cobalt surface, we set the threshold coverage as 1/3 ML. The differential chemisorption energy can be divided into two parts, namely the low coverage region and high coverage region. 
The low coverage region can be fitted as a linear curve and the high coverage region can be fitted as a quadric curve.

For the other adsorbates, the differential chemisorption energies are expressed as:

$\mathrm{E}_{\mathrm{i}}\left(\theta_{\mathrm{i}}\right)=\mathrm{E}_{\mathrm{i}}^{0} \quad$ when $\theta_{\mathrm{CO}} \leq \theta_{0}$

$\mathrm{E}_{\mathrm{i}}\left(\theta_{\mathrm{CO}}\right)=\mathrm{f}_{\mathrm{i}}\left(\theta_{\mathrm{CO}}\right) \quad$ when $\theta_{\mathrm{CO}}>\theta_{0}$

where $\mathrm{E}_{\mathrm{i}}\left(\theta_{\mathrm{CO}}\right)$ is the differential chemisorption energy of adsorbate $\mathrm{i}$ under the $\mathrm{CO}$ environment at coverage $\theta_{\mathrm{CO}}$. The flow chart is showed in Figure 3.

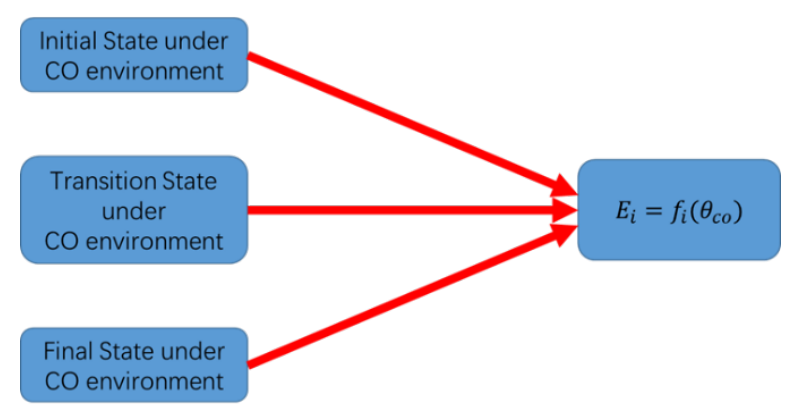

Figure 3. Flow chart of fitting energy for the coverage dependent kinetic modelling.

The concept of iteration is displayed in Figure 4. All the chemisorption energies of each intermediate as a function of the $\mathrm{CO}$ coverage were obtained. All the barriers and reaction energies were also obtained by fitting the function $\mathrm{f}_{\mathrm{i}}\left(\theta_{\text {co }}\right)$ at different coverages of $\mathrm{CO}$. We ignored other species affecting $\mathrm{CO}$ chemisorption. One has to use the approximation to describe complicated reactions such as the FT reaction involving a large number of elementary reaction steps and many intermediates in the coverage dependent model for practical use. ${ }^{51}$ Despite of the simplification, this work provides fundamental insight into the complex reactions such as the FT process. 


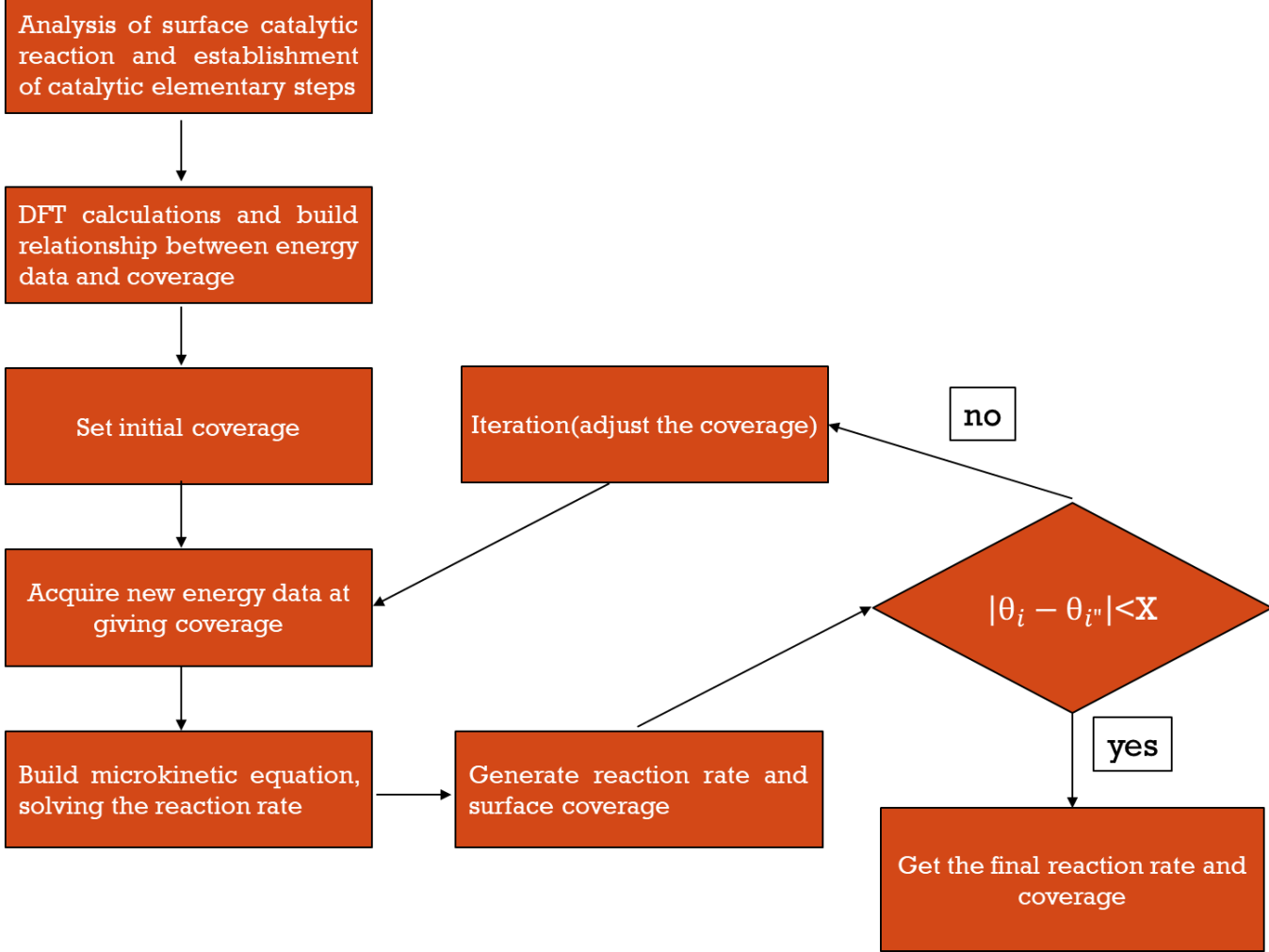

Figure 4. Illustration of iterations of the coverage dependent microkinetic model.

\section{RESULTS}

\subsection{Application of the Quasi-equilibrium Approximation}

Cheng et al. ${ }^{81-87}$ used the quasi-equilibrium approximation to investigate the FT mechanism on a cobalt surface based on the DFT calculations and the concept of effective barriers was derived. In this section, we will use this concept to characterize the mechanisms on the flat cobalt surface. Monomer coverages can be calculated as follows: ${ }^{81}$

$\theta_{\mathrm{CH}_{\mathrm{i}}}=\mathrm{e}^{\frac{-\mathrm{E}_{\mathrm{i}}}{\mathrm{RT}}} \theta_{\mathrm{C}} \mathrm{t}^{\mathrm{i}}$

where $t$ is the ratio of $\frac{\theta_{\mathrm{H}}}{\theta_{*}}$, and $\mathrm{E}_{\mathrm{i}}$ is relative energy between $\mathrm{CH}_{\mathrm{i}}$ and $\mathrm{C}$.

The details of the calculations can be found in the supporting information. 


\subsubsection{Comparison among the Mechanisms of Carbide, $\mathrm{CO}$ Insertion and $\mathrm{CHO}$ Insertion}

We select the most probable coupling pathways among the carbide mechanism, the $\mathrm{CO}$ insertion mechanism and the $\mathrm{CHO}$ insertion mechanism and list them as follows:

$\mathrm{r}_{\mathrm{CH}+\mathrm{CH}}=1.3 \times 10^{7} \mathrm{t}^{2} \theta_{\mathrm{C}}^{2}$

$\mathrm{r}_{\mathrm{CH}+\mathrm{CO}}=7.8 \times 10^{3} \mathrm{t} \theta_{\mathrm{C}} \theta_{\mathrm{CO}}$

$\mathrm{r}_{\mathrm{CH}_{2}+\mathrm{CHO}}=5.7 \times 10^{7} \mathrm{t}^{2} \theta_{\mathrm{C}} \theta_{\mathrm{CHO}}$

First, comparing $\mathrm{r}_{\mathrm{CH}+\mathrm{CH}}$ and $\mathrm{r}_{\mathrm{CH}+\mathrm{CO}}$, we can obtain

$\frac{\mathrm{r}_{\mathrm{CH}+\mathrm{CH}}}{\mathrm{r}_{\mathrm{CH}+\mathrm{CO}}}=1.7 \times 10^{3} \mathrm{t} \frac{\theta_{\mathrm{C}}}{\theta_{\mathrm{CO}}}$

$\mathrm{r}_{\mathrm{CH}+\mathrm{CH}}>\mathrm{r}_{\mathrm{CH}+\mathrm{CO}}$ if $1.7 \times 10^{3} \mathrm{t} \theta_{\mathrm{C}}>\theta_{\mathrm{CO}}\left(\frac{\theta_{\mathrm{C}}}{\theta_{\mathrm{CO}}}>\frac{1}{1.7 \times 10^{3} \mathrm{t}}\right)$

$\mathrm{r}_{\mathrm{CH}+\mathrm{CH}}=\mathrm{r}_{\mathrm{CH}+\mathrm{CO}}$ if $1.7 \times 10^{3} \mathrm{t} \theta_{\mathrm{C}}=\theta_{\mathrm{CO}}\left(\frac{\theta_{\mathrm{C}}}{\theta_{\mathrm{CO}}}=\frac{1}{1.7 \times 10^{3} \mathrm{t}}\right)$

$\mathrm{r}_{\mathrm{CH}+\mathrm{CH}}<\mathrm{r}_{\mathrm{CH}+\mathrm{CO}}$ if $1.7 \times 10^{3} \mathrm{t} \theta_{\mathrm{C}}<\theta_{\mathrm{CO}}\left(\frac{\theta_{\mathrm{C}}}{\theta_{\mathrm{CO}}}<\frac{1}{1.7 \times 10^{3} \mathrm{t}}\right)$

Although this approximation is not very precise, it gives us some insight into the reaction kinetics. If the ratio of $\frac{\theta_{\mathrm{C}}}{\theta_{\mathrm{CO}}}$ is increased, it is more likely to be carbide mechanism. Then, comparing $\mathrm{r}_{\mathrm{CH}+\mathrm{CH}}$

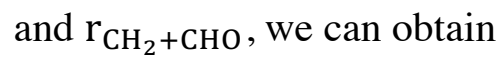

$\frac{\mathrm{r}_{\mathrm{CH}+\mathrm{CH}}}{\mathrm{r}_{\mathrm{CH}_{2}+\mathrm{CHO}}}=0.23 \frac{\theta_{\mathrm{C}}}{\theta_{\mathrm{CHO}}}$

$\mathrm{r}_{\mathrm{CH}+\mathrm{CH}}>\mathrm{r}_{\mathrm{CH}_{2}+\mathrm{CHO}}$ if $0.23 \theta_{\mathrm{C}}>\theta_{\mathrm{CHO}}\left(\frac{\theta_{\mathrm{C}}}{\theta_{\mathrm{CHO}}}>4.3\right)$

$\mathrm{r}_{\mathrm{CH}+\mathrm{CH}}<\mathrm{r}_{\mathrm{CH}_{2}+\mathrm{CHO}}$ if $0.23 \theta_{\mathrm{C}}=\theta_{\mathrm{CHO}}\left(\frac{\theta_{\mathrm{C}}}{\theta_{\mathrm{CHO}}}=4.3\right)$

$\mathrm{r}_{\mathrm{CH}+\mathrm{CH}}<\mathrm{r}_{\mathrm{CH}_{2}+\mathrm{CHO}}$ if $0.23 \theta_{\mathrm{C}}<\theta_{\mathrm{CHO}}\left(\frac{\theta_{\mathrm{C}}}{\theta_{\mathrm{CHO}}}<4.3\right)$

Also, as the ratio of $\frac{\theta_{\mathrm{C}}}{\theta_{\mathrm{CHO}}}$ is increased, it is more likely to take the carbide pathway. Due to the short lifetime of $\mathrm{CHO}$, its presence is very difficult to characterize.$^{46,88-90}$ Because of the very low 
coverage of $\mathrm{CHO}$ on the surface, it is likely that the contribution of the $\mathrm{CHO}$ insertion mechanism is much smaller than that of the carbide mechanism (see below).

Overall, the most likely coupling mechanisms on $\mathrm{Co}(0001)$ are the carbide mechanism and the $\mathrm{CO}$ insertion mechanism. Compared with the flat $\mathrm{Co}(0001)$ surface, the carbide mechanism is more likely to occur at a cobalt surface with defects. ${ }^{91-92}$ The defective surface is more prone to activating $\mathrm{CO}$ dissociation: On the stepped cobalt surfaces, for example, $\mathrm{C}$ is the most stable species, and thus it is more likely to have high a surface coverage on the stepped surface. ${ }^{81}$

From the result of relative stabilities of monomers on the flat cobalt surface, we can find that the stabilities are in the following order: $\mathrm{CH}>\mathrm{C}>\mathrm{CH}_{3}>\mathrm{CH}_{2} ; \mathrm{CH}$ is the most stable species on the surface rather than $\mathrm{C}$, which is consistent with the result of Cheng et al.$^{81}$ There is still a possibility that the contribution of the $\mathrm{CO}$-insertion mechanism is larger than the carbide mechanism on the flat cobalt surface if the coverage of monomers $\mathrm{CH}_{\mathrm{x}}$ is low.

\subsection{Comparison of the Intermediate Stabilities between the Non-coverage-dependent and Coverage-dependent Kinetic Modelling at $500 \mathrm{~K}$}

Thanks to the concept of relative stabilities of intermediates from Filot et al., ${ }^{53}$ we applied this concept to the analysis of intermediates on the surface with the van der Waals interactions which are significant, and cannot, therefore, be ignored in the simulations..$^{51,72,93-96}$ The stabilities are with respect to the most stable adsorbates $\mathrm{C}, \mathrm{H}$, and $\mathrm{O}$ and can be calculated by the following equation: $\mathrm{E}_{\text {stability }}=\mathrm{E}_{\text {met+adsorbate }}-\mathrm{a}\left(\mathrm{E}_{\text {met }+\mathrm{C}}\right)-\mathrm{b}\left(\mathrm{E}_{\text {met }+\mathrm{H}}\right)-\mathrm{c}\left(\mathrm{E}_{\text {met }+\mathrm{O}}\right)+(\mathrm{a}+\mathrm{b}+\mathrm{c}-1) * \mathrm{E}_{\text {met }}$

where $E_{\text {stability }}$ is the relative stability of an adsorbate on the metal surface, $E_{\text {met+adsorbate }}$ represents the energy of the metal surface with the adsorbate, $E_{\text {met }+X}$ is the energy of the metal surface with $\mathrm{X}$ where $\mathrm{X}$ is $\mathrm{C}$ or $\mathrm{H}$ or $\mathrm{O}, \mathrm{a}, \mathrm{b}$ and $\mathrm{c}$ are the numbers of atoms of $\mathrm{C}, \mathrm{H}, \mathrm{O}$ in the adsorbate individually, and $\mathrm{E}_{\mathrm{met}}$ is the energy of the metal surface.

As shown in Figure 5, $\mathrm{CHCH}, \mathrm{CCH}$ and $\mathrm{CO}$ are the most stable species from both models. As the monomers will significantly affect the rate, there should be a greater focus on the stabilities of the monomers. For the monomers of $\mathrm{C}, \mathrm{CH}, \mathrm{CH}_{2}, \mathrm{CH}_{3}$, the stabilities without lateral interactions are in the order of $\mathrm{CH}>\mathrm{C}>\mathrm{CH}_{3}>\mathrm{CH}_{2}$, with the stability of $\mathrm{CH}_{3}$ being only a little higher than $\mathrm{CH}_{2}$. The result of the low stability of $\mathrm{CH}_{2}$ is consistent with the literature. ${ }^{97-98}$ However, this order 
changes if we consider the coverage effect, and the stabilities with lateral interactions included are the following order: $\mathrm{CH}>\mathrm{C}>\mathrm{CH}_{2}>\mathrm{CH}_{3}$ : $\mathrm{CH}$ becomes much more stable than $\mathrm{C}$, while the stability of $\mathrm{CH}_{2}$ remains nearly the same and $\mathrm{CH}_{3}$ becomes less stable. It illustrates the fact that different species possess different lateral interactions with co-adsorbed CO. In the coverage-dependent model, $\mathrm{CO}$ is the most stable species in our system, and it is consistent with the result of high $\mathrm{CO}$ coverage in Figure 5. We also find that $\mathrm{COH}$ and $\mathrm{CH}_{3} \mathrm{O}$ are relatively more stable with the consideration of the coverage effect. Interestingly, $\mathrm{CHCH}$ is the second most stable species on the surface with the value of $-0.77 \mathrm{eV}$, and it is less stable than $\mathrm{CH}+\mathrm{CH}(-0.84 \mathrm{eV})$. Based on this, $\mathrm{CHCH}$ may be very likely to dissociate into two $\mathrm{CH}$ monomers. For the other notable species like $\mathrm{CCH}_{3}$ and $\mathrm{CHCO}$, they all show high stability on the surface, and they are important species to form long chain hydrocarbons.

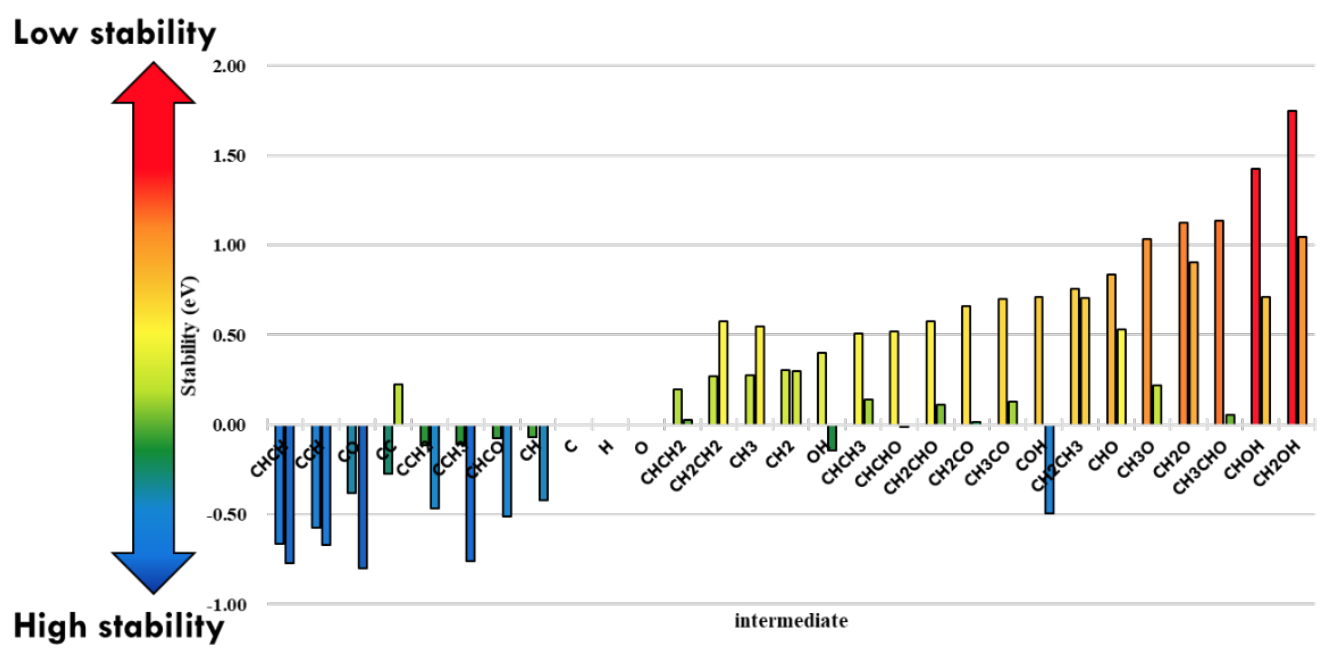

Figure 5. Stability bars of intermediates at $500 \mathrm{~K}$. Negative stability means more stable and positive stability means less stable (equation 23). The unit of stability is in eV. For each intermediate, the left bar represents the stability without coverage effects, and the right bar represents the stability with the coverage effects.

\subsection{Comparison of the Reaction Pathways between the Non-coverage-dependent Coverage- dependent Kinetic Modelling at $500 \mathrm{~K}$}

3.3.1. $C_{1}$ Reaction Pathways

If we compare the $\mathrm{C}_{1}$ reaction pathways between the non-coverage-dependent model and the coverage-dependent model in Figure 6, we can find that the TOF on the coverage-dependent model 
simulations is much higher. As the direct $\mathrm{CO}$ dissociation is difficult on the flat cobalt surface, $\mathrm{H}$ assisted $\mathrm{CO}$ dissociation is the dominant pathway to break the $\mathrm{C}-\mathrm{O}$ bond. The microkinetic results indicate that most $\mathrm{C}_{1}$ oxygenates are likely to dissociate into monomers. This additional formation of monomers increases the likelihood of forming long chain hydrocarbons. Carefully comparing the monomer formation for the $\mathrm{C}_{1}$ reaction pathways from both models, we can see that the reaction pathways are similar. There are three pathways to form monomer $\mathrm{CH}$, namely $\mathrm{H}^{*}+\mathrm{C}^{*} \rightarrow \mathrm{CH}^{*}+^{*}$, $\mathrm{CHO}^{*}+* \rightarrow \mathrm{CH}^{*}+\mathrm{O}^{*}, \mathrm{CHOH}^{*}+* \rightarrow \mathrm{CH}^{*}+\mathrm{OH}^{*}$. The dominant reaction pathway is $\mathrm{CHO}^{*}+* \rightarrow$ $\mathrm{CH}^{*}+\mathrm{O}^{*}$ from non-coverage dependent model, but it is changed to $\mathrm{CHOH}^{*}+* \rightarrow \mathrm{CH}^{*}+\mathrm{OH}^{*}$ from the coverage-dependent model. The reaction of $\mathrm{CHOH}$ dissociation is more likely to occur on the flat surface. ${ }^{99-101}$

Regarding the monomer of $\mathrm{CH}_{2}$, there are four pathways, namely $\mathrm{H}^{*}+\mathrm{CH}^{*} \rightarrow \mathrm{CH}_{2}^{*}+*, \mathrm{CH}_{2} \mathrm{O}^{*}+*$ $\rightarrow \mathrm{CH}_{2}{ }^{*}+\mathrm{O}^{*}, \mathrm{CH}_{2} \mathrm{OH}^{*}+* \rightarrow \mathrm{CH}_{2}{ }^{*}+\mathrm{OH}^{*}, \mathrm{CH}_{3}{ }^{*}{ }^{*} \rightarrow \mathrm{CH}_{2}{ }^{*}+\mathrm{H}^{*}$. The dominant reaction pathway is only $\mathrm{CH}_{2} \mathrm{OH}^{*}+* \rightarrow \mathrm{CH}_{2} *+\mathrm{OH}^{*}$ for the non-coverage-dependent model, but it changes to $\mathrm{CH}_{3}{ }^{*}+\rightarrow \mathrm{CH}_{2}{ }^{*}+\mathrm{H}^{*}$ and $\mathrm{CH}_{2} \mathrm{OH}^{*}+* \rightarrow \mathrm{CH}_{2}{ }^{*}+\mathrm{OH}^{*}$ if we consider the coverage effect. The increased stability of $\mathrm{CH}_{2}$ on the surface promotes $\mathrm{CH}_{3}$ dehydrogenation to form $\mathrm{CH}_{2}$, which leads to the selectivity towards methane being suppressed on the flat cobalt surface. The formation of $\mathrm{CH}_{2}$ is very important, as the $\mathrm{CH}_{2}$ monomer is crucial for the chain formation during the FT process. Many DFT calculations and experiments have suggested that $\mathrm{CH}_{2}$ is the most important species on the surface, regardless whether the carbide mechanism or the $\mathrm{CO}$-insertion mechanism is the predominant pathway. ${ }^{33,45,81}$ As for the monomer formation of $\mathrm{CH}_{3}$, both models show that $\mathrm{CH}_{3} \mathrm{O} *+* \rightarrow \mathrm{CH}_{3}^{*}+\mathrm{O}^{*}$ is the dominant pathway. 

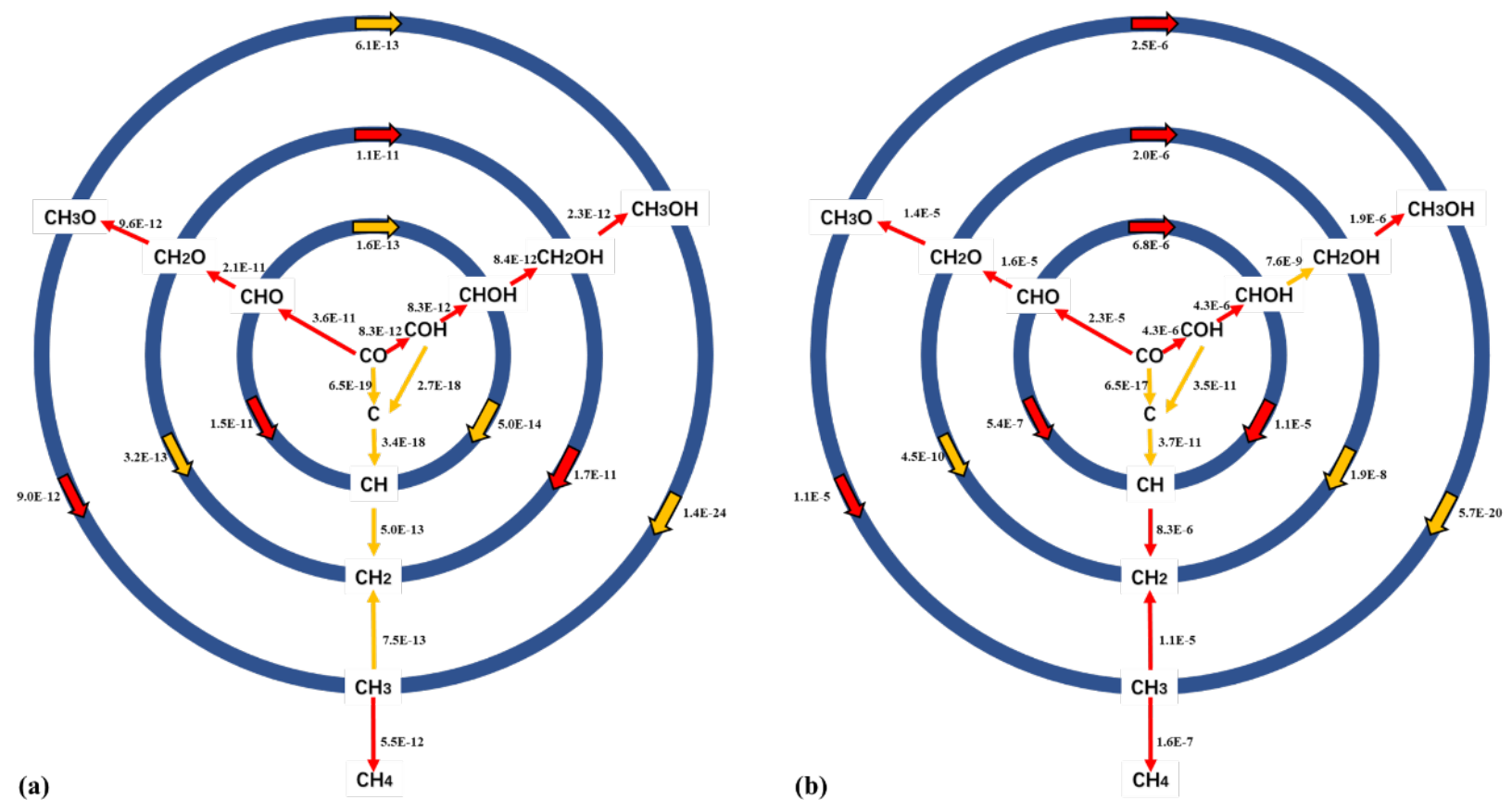

Figure 6. (a) Non-coverage dependent pathways for $C_{1}$ species. Red arrow represents the important pathways according to the results of the microkinetic model simulations. The values represent the reaction rates for each elementary steps and unit is $\mathrm{s}^{-1}$. (b) Coverage dependent pathways for $\mathrm{C}_{1}$ species.

\subsection{2. $\mathrm{C}_{2}$ Reaction Pathways}

$\mathrm{C}_{2}$ reaction pathways for the non-coverage-dependent model and the coverage-dependent model are shown in Figure 7. Three possible chain growth mechanisms are included in our microkinetic model: the carbide mechanism; the $\mathrm{CO}$ insertion mechanism; and the $\mathrm{CHO}$ insertion mechanism. Both models indicate that the possibility of the contribution from the CO-insertion mechanism is larger than the carbide mechanism on the flat cobalt since the coverage of monomer $\mathrm{C}$ is not very high. The coupling of $\mathrm{CO}+\mathrm{CH}_{2}$ is the dominant chain growth pathway to form $\mathrm{C}_{2}$ species. The $\mathrm{CHO}$ insertion is found to contribute very little to the reaction.

In section 3.1, we discussed that the elementary step of $\mathrm{CH}^{*}+\mathrm{CH}^{*} \rightarrow \mathrm{CHCH}^{*}+*$ would be the most likely reaction pathway if the carbide mechanism is the dominant chain growth mechanism. However, the CO dissociation is difficult on the flat cobalt surface, which is different from the stepped cobalt surface, and thus the monomers cannot achieve a certain coverage on the surface. From the non-coverage-dependent model, the coverage of $\mathrm{CH}$ is of the order of $10^{-12}$, and from our 
coverage-dependent model, the coverage of $\mathrm{CH}$ is of the order of $10^{-6}$. In other words, the possibility of $\mathrm{CH}$ reacting with another $\mathrm{CH}$ is lower than that of $\mathrm{CH}$ reacting with $\mathrm{CO}$. $\mathrm{CO}$ is likely to insert into $\mathrm{CH}$ or $\mathrm{CH}_{2}$, and then after forming $\mathrm{CH}_{3} \mathrm{CO}$, the $\mathrm{C}-\mathrm{O}$ bond is broken, yielding the intermediate species $\mathrm{CCH}_{3}$. After several hydrogenation or dehydrogenation steps, olefin and paraffin are produced.
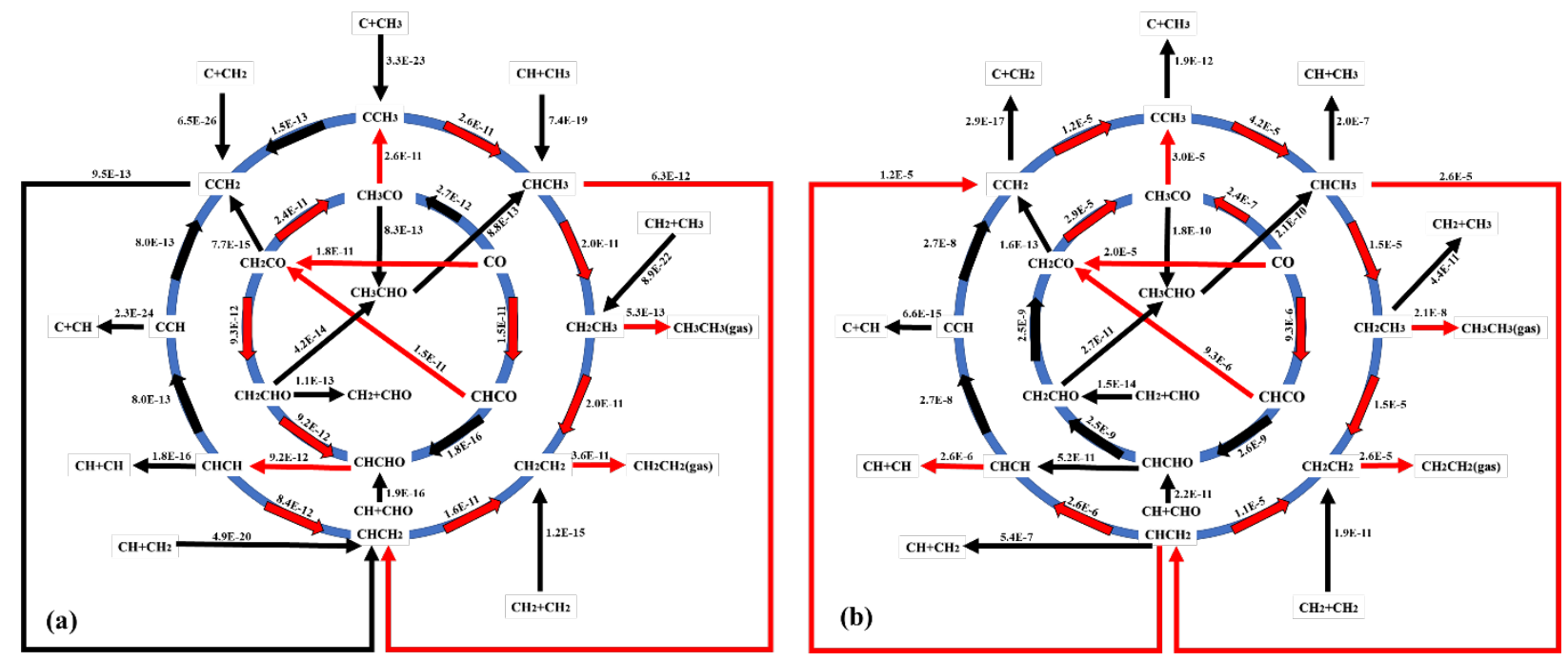

Figure 7. (a) Non-coverage dependent pathways for $\mathrm{C}_{2}$ species. Red arrow represents the important pathways according the results of microkinetic model. The values represent the reaction rates for each elementary steps and unit is $\mathrm{s}^{-1}$. (b) Coverage dependent pathways for $\mathrm{C}_{2}$ species.

\subsubsection{Chain Growth Mechanisms on the Flat Co(0001) Surface}

Based on the section 3.3.1 and section 3.3.2, we propose the generalized CO insertion mechanism, as shown in Figure 8. On the flat cobalt surface, the $\mathrm{CH}$ monomer is mainly provided by $\mathrm{CHOH}$ dissociation. The $\mathrm{CH}$ monomers may also be supplied by the dissociations of $\mathrm{RCCH}$ and dissociation of $\mathrm{RCHCH}$, and $\mathrm{RCH}_{2} \mathrm{CH}$ also contributes towards the formation of $\mathrm{CH}$. Because of the dissociations, the carbide mechanism may be suppressed. CO probably inserts into CR or CHR first, and subsequently form $\mathrm{RCH}_{2} \mathrm{CO}$. Next, the $\mathrm{C}-\mathrm{O}$ bond is broken, yielding the intermediate species $\mathrm{RCH}_{2} \mathrm{C}$. Then olefin and paraffin are produced through hydrogenation or dehydrogenation steps of $\mathrm{RCH}_{2} \mathrm{C}$. 


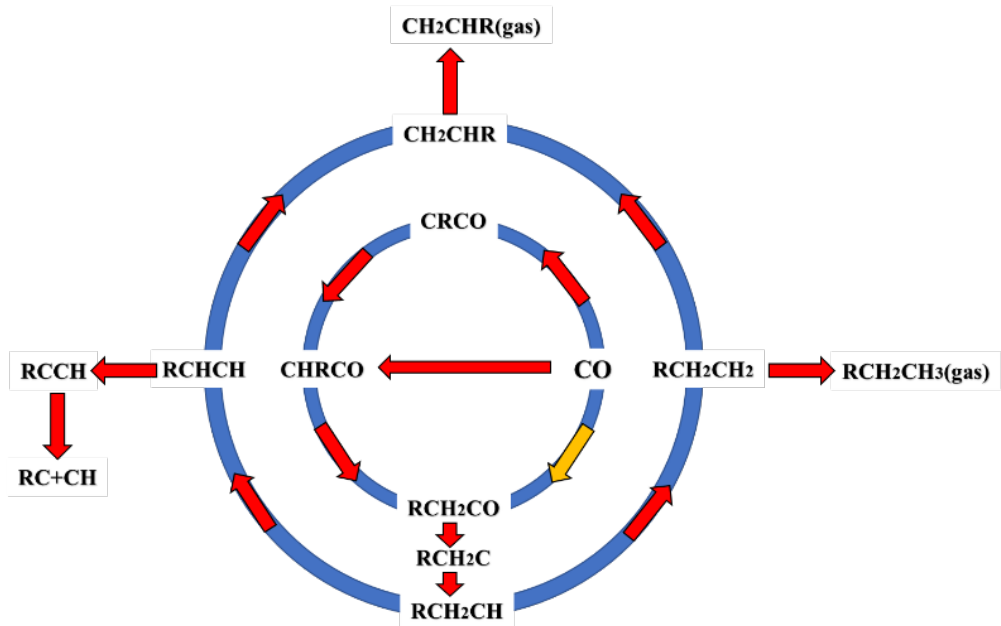

Figure 8. Chain growth mechanism of FT synthesis based on our coverage dependent microkinetic model results

\subsection{Comparison of the Activity/Selectivity between the Non-coverage-dependent and Coverage-dependent Kinetic Modelling at $500 \mathrm{~K}$}

Figure 9 shows the activity and selectivity for the FT process on the cobalt surface. Both models indicate the high selectivity towards ethylene. The selectivity for the non-coverage-dependent model follows the order: $\mathrm{C}_{2} \mathrm{H}_{4}>\mathrm{CH}_{4}>\mathrm{CH}_{3} \mathrm{OH}>\mathrm{C}_{2} \mathrm{H}_{6}$. From the coverage-dependent model, it is the following: $\mathrm{C}_{2} \mathrm{H}_{4}>\mathrm{CH}_{3} \mathrm{OH}>\mathrm{CH}_{4}>\mathrm{C}_{2} \mathrm{H}_{6}$. This causes an interesting question to arise: Why is the selectivity of $\mathrm{CH}_{3} \mathrm{OH}$ greater than that of $\mathrm{CH}_{4}$ on the coverage-dependent model? The question can be answered as follows: After considering the coverage effect, firstly the stability of $\mathrm{CH}_{3} \mathrm{O}$ increases from $1.04 \mathrm{eV}$ to $0.22 \mathrm{eV}$, and secondly the barrier for $\mathrm{CH}_{3} \mathrm{O}$ dissociation is increased by $0.1 \mathrm{eV}$. These two reasons lead to the coverage of $\mathrm{CH}_{3} \mathrm{O}$ being higher from the non-coveragedependent model; the increased coverage of $\mathrm{CH}_{3} \mathrm{O}$ promotes the formation of $\mathrm{CH}_{3} \mathrm{OH}$. The total consumption rate at $500 \mathrm{~K}$ is of the order of $10^{-5} \mathrm{~s}^{-1}$ from the coverage-dependent model, which is much higher than that of the non-coverage-dependent model that gives rise to the order of $10^{-11} \mathrm{~s}^{-}$ 1. This is consistent with the results in the literature: It was reported that the flat $\mathrm{Rh}(111)$ surface is not selective towards methane, and the existence of the $\mathrm{Rh}(211)$ surface (stepped) leads to the formation methane..$^{51}$ Hence, our results suggest that the formation of the defect sites is one of the main reason for the increased selectivity of methane. 

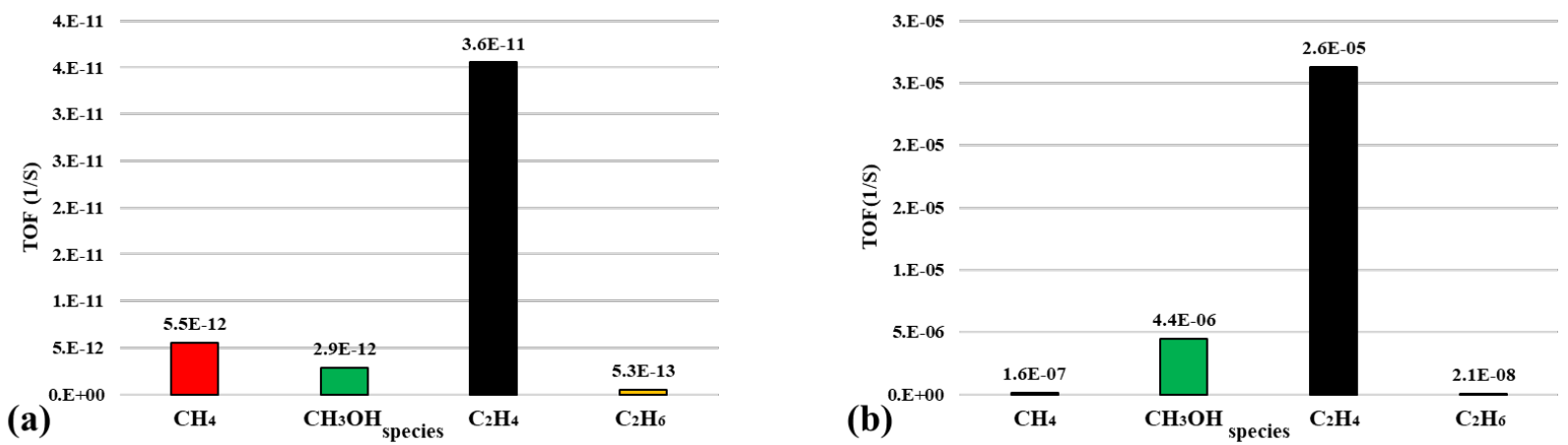

Figure 9. (a) Turnover frequencies (TOF) for methane, methanol, ethylene, ethane for noncoverage dependent model. (b) Turnover frequencies (TOF) for methane, methanol, ethylene, ethane for coverage dependent model. The reaction conditions are $\mathrm{T}=500 \mathrm{~K}, \mathrm{P}_{\mathrm{CO}}=3.33$ bar, $\mathrm{P}_{\mathrm{H}_{2}}=6.67$ bar.

\subsection{Coverage Comparison between the Non-coverage-dependent and Coverage-dependent}

\section{Kinetic Modelling at $500 \mathrm{~K}$}

The coverage is one of the most important factors that determine the final TOF. The coverages of surface species without the lateral interaction are shown in Table 2. It can be seen that because $\mathrm{CO}$ is the most abundant species in FT synthesis, from the non-coverage dependent model, $\mathrm{CO}$ considerably blocks all the sites on the surface which leads to other species having low coverages on the surface. This is clearly illustrated in Figure 10. The chemisorption energy without the lateral interaction is highly overestimated, leading to the unrealistic TOF. After we considered the coverage effect, $\mathrm{CO}$ is no longer the only species with high coverage on the surface, although it is still the most abundant species; the coverages of surface species are shown in the Table 3 and illustrated in Figure 10b. 
Table 2. Coverages of intermediates from non-coverage dependent microkinetic model simulations.

\begin{tabular}{|c|c|c|c|}
\hline species & coverage & species & coverage \\
\hline $\mathrm{CO}$ & 0.997 & $\mathrm{CH}_{2} \mathrm{CO}$ & $1.1 \mathrm{E}-09$ \\
\hline $\mathrm{CH}_{3} \mathrm{O}$ & 0.003 & $\mathrm{CCH}_{3}$ & $2.1 \mathrm{E}-10$ \\
\hline $\mathrm{O}$ & 0.0001 & $\mathrm{v}$ & $1.5 \mathrm{E}-10$ \\
\hline $\mathrm{CH}_{2} \mathrm{CHO}$ & $6.0 \mathrm{E}-05$ & $\mathrm{CH}_{2} \mathrm{OH}$ & $1.3 \mathrm{E}-10$ \\
\hline $\mathrm{CHCO}$ & $3.7 \mathrm{E}-06$ & $\mathrm{CH}_{2} \mathrm{CH}_{2}$ & 7.3E-11 \\
\hline $\mathrm{CH}_{3} \mathrm{CO}$ & $3.4 \mathrm{E}-06$ & $\mathrm{CHOH}$ & $2.7 \mathrm{E}-11$ \\
\hline $\mathrm{H}$ & $1.2 \mathrm{E}-06$ & $\mathrm{CH}_{2} \mathrm{CH}_{3}$ & $7.0 \mathrm{E}-12$ \\
\hline $\mathrm{CH}_{3} \mathrm{CHO}$ & $1.2 \mathrm{E}-06$ & $\mathrm{CCH}$ & 4.4E-12 \\
\hline $\mathrm{CHCH}$ & 3.3E-07 & $\mathrm{CH}_{2}$ & 4.4E-12 \\
\hline $\mathrm{OH}$ & 7.5E-08 & $\mathrm{CH}$ & $3.0 \mathrm{E}-12$ \\
\hline $\mathrm{CH}_{3}$ & $6.6 \mathrm{E}-08$ & $\mathrm{CHCH}_{3}$ & $9.7 \mathrm{E}-13$ \\
\hline $\mathrm{COH}$ & $5.4 \mathrm{E}-08$ & $\mathrm{CHCH}_{2}$ & $1.1 \mathrm{E}-13$ \\
\hline $\mathrm{CH}_{2} \mathrm{O}$ & 4.4E-08 & $\mathrm{CCH}_{2}$ & 2.7E-14 \\
\hline CHCHO & $3.0 \mathrm{E}-08$ & $\mathrm{C}$ & 8.2E-17 \\
\hline $\mathrm{CHO}$ & 4.3E-09 & $\mathrm{CC}$ & 5.3E-19 \\
\hline
\end{tabular}


Table 3. Coverages of intermediates from the coverage-dependent microkinetic model simulations.

\begin{tabular}{|c|c|c|c|}
\hline species & coverage & species & coverage \\
\hline $\mathrm{CO}$ & 0.60 & $\mathrm{CH}_{3}$ & $7.1 \mathrm{E}-10$ \\
\hline $\mathrm{COH}$ & 0.21 & $\mathrm{CH}_{3} \mathrm{CO}$ & $6.8 \mathrm{E}-10$ \\
\hline $\mathrm{CH}_{3} \mathrm{O}$ & 0.11 & $\mathrm{CHOH}$ & $2.1 \mathrm{E}-10$ \\
\hline $\mathrm{H}$ & 0.08 & $\mathrm{CH}_{2}$ & $1.3 \mathrm{E}-10$ \\
\hline $\mathrm{CCH}_{3}$ & 0.002 & $\mathrm{CCH}$ & $8.2 \mathrm{E}-11$ \\
\hline $\mathrm{OH}$ & 0.0003 & $\mathrm{CHO}$ & $3.2 \mathrm{E}-11$ \\
\hline $\mathrm{v}$ & $5.2 \mathrm{E}-05$ & $\mathrm{CHCH}_{2}$ & $1.9 \mathrm{E}-11$ \\
\hline $\mathrm{O}$ & 2.7E-05 & $\mathrm{CHCHO}$ & $1.2 \mathrm{E}-11$ \\
\hline $\mathrm{CH}_{3} \mathrm{CHO}$ & $6.4 \mathrm{E}-06$ & $\mathrm{CH}_{2} \mathrm{O}$ & $8.2 \mathrm{E}-12$ \\
\hline $\mathrm{CH}$ & $1.6 \mathrm{E}-06$ & $\mathrm{CH}_{2} \mathrm{CO}$ & $6.8 \mathrm{E}-12$ \\
\hline $\mathrm{CHCH}$ & $1.4 \mathrm{E}-06$ & $\mathrm{CH}_{2} \mathrm{CH}_{3}$ & $5.8 \mathrm{E}-12$ \\
\hline $\mathrm{CHCH}_{3}$ & 2.1E-09 & $\mathrm{CH}_{2} \mathrm{OH}$ & $4.3 \mathrm{E}-12$ \\
\hline $\mathrm{CCH}_{2}$ & $1.1 \mathrm{E}-09$ & $\mathrm{C}$ & $5.9 \mathrm{E}-14$ \\
\hline $\mathrm{CH}_{2} \mathrm{CHO}$ & $1.1 \mathrm{E}-09$ & $\mathrm{CH}_{2} \mathrm{CH}_{2}$ & $6.7 \mathrm{E}-17$ \\
\hline $\mathrm{CHCO}$ & $8.2 \mathrm{E}-10$ & $\mathrm{CC}$ & $5.7 \mathrm{E}-23$ \\
\hline
\end{tabular}

(a)

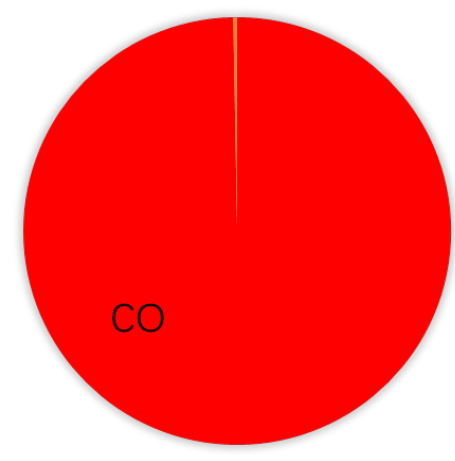

(b)

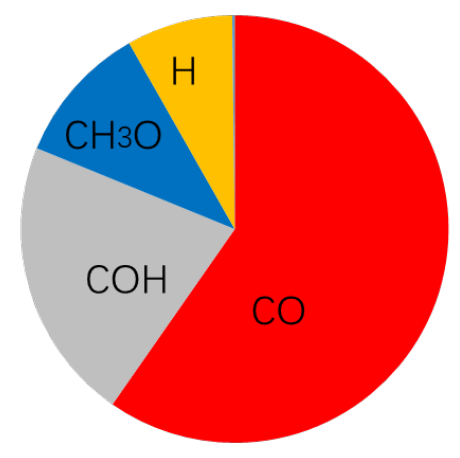

Figure 10. Coverage distributions from simulations of the non-coverage dependent model (a); the coverage dependent model (b).

Although the coverage of the monomer has been greatly increased after considering the influence of the adsorbate-adsorbate interaction, the flat cobalt surface lacks the B5 site, leading to the 
carbon monoxide being unable to effectively dissociate. Furthermore, the formation of the monomer is suppressed, resulting to the $\mathrm{CO}$ insertion mechanism becoming dominant. On the other hand, the adsorbate-adsorbate interaction can lead to some surface areas originally blocked by $\mathrm{CO}$ being replaced by $\mathrm{COH}, \mathrm{CH}_{3} \mathrm{O}, \mathrm{H}, \mathrm{CCH}_{3}, \mathrm{OH}$ and vacancy; the high-coverage $\mathrm{COH}$ changes the dominant dissociation mechanism from the original $\mathrm{CHO}^{*}+* \rightarrow \mathrm{CH}^{*}+\mathrm{O}^{*}$ to the $\mathrm{COH}^{*}+\mathrm{H}^{*} \rightarrow$ $\mathrm{CHOH}^{*}+*, \mathrm{CHOH}^{*}+* \rightarrow \mathrm{CH}^{*}+\mathrm{OH}^{*}$. The high coverages of $\mathrm{CH}_{3} \mathrm{O}$ and $\mathrm{CCH}_{3}$ greatly enhance the activity of forming $\mathrm{CH}_{3} \mathrm{OH}$ and $\mathrm{CH}_{2} \mathrm{CH}_{2}$, respectively. More importantly, the increase in $\mathrm{H}$ coverage boosts the rates of hydrogenation reactions, and the increase in vacancy coverage contributes to dissociations and generating more monomers. In the discussion section below, we will reveal the coverage changes versus temperature to further understand the trends of the activity and selectivity.

\section{DISCUSSIONS}

\subsection{Temperature Effects from $425 \mathrm{~K}$ to $700 \mathrm{~K}$ on the Activity and Selectivity from the Coverage-dependent Kinetic Modelling}

We used the coverage-dependent microkinetic model to calculate the reaction rate and the selectivity as a function of temperature. The selected partial pressure of CO is $3.33 \mathrm{bar}$, and the partial pressure of $\mathrm{H}_{2}$ is 6.67 bar. The activity and selectivity on the cobalt surface from $425 \mathrm{~K}$ and $700 \mathrm{~K}$ were investigated, and the results are shown in Figure 11. The kinetic results show that the total TOF increases with the temperature. With respect to the selectivity, we find that it changes dramatically as a function of temperature.

The selectivity towards $\mathrm{C}_{2} \mathrm{H}_{4}$ is dominant in the temperature range from $425 \mathrm{~K}$ to $675 \mathrm{~K}$, and if the temperature is higher than $675 \mathrm{~K}$, the dominant product changes to methane. It should be mentioned that the maximum selectivity of $\mathrm{C}_{2} \mathrm{H}_{4}$ appears at the temperature of $525 \mathrm{~K}$. When we carefully examined the coverages of main species with temperature, which are displayed in Figure 12 , we found that the coverage of $\mathrm{CCH}_{3}$ reaches a peak at $525 \mathrm{~K}$. Both the high coverages of $\mathrm{CCH}_{3}$ and $\mathrm{CO}$ can lead to high selectivity of $\mathrm{C}_{2} \mathrm{H}_{4}$. Clearly, the increase of temperature will accelerate the overall reaction, and $\mathrm{CH}_{3} \mathrm{O}$ will be consumed very quickly. Other species such as $\mathrm{CO}, \mathrm{CH}_{3} \mathrm{C}$ and $\mathrm{COH}$ will then occupy surface sites which were previously filled by $\mathrm{CH}_{3} \mathrm{O}$. When the 
temperature is higher than $525 \mathrm{~K}$, the coverages of $\mathrm{CO}, \mathrm{CH}_{3} \mathrm{C}$, and $\mathrm{COH}$ begin to decrease very quickly and the coverages of $\mathrm{H}$ and vacant sites will increase.

$\mathrm{CH}_{3} \mathrm{OH}$ is the second most dominant product from $425 \mathrm{~K}$ to $560 \mathrm{~K}$. If the temperature is higher than $560 \mathrm{~K}$, the selectivity of methane begins to exceed the selectivity of $\mathrm{CH}_{3} \mathrm{OH}$. The selectivity of $\mathrm{CH}_{3} \mathrm{OH}$ is controlled by the coverage of $\mathrm{CH}_{3} \mathrm{O}$ from $425 \mathrm{~K}$ to $525 \mathrm{~K}$ and in this temperature region, the selectivity of oxygenate formation is higher at $425 \mathrm{~K}$ and then decreases dramatically with increasing temperature. In the same temperature region from $425 \mathrm{~K}$ to $525 \mathrm{~K}, \mathrm{C}_{2}$ selectivity follows the reverse trend of the oxygenate. Our predicted selectivity on the flat cobalt surface is very similar to that of the experiment: ${ }^{102}$ Pendyala et al. used un-promoted and Pt promoted $25 \%$ $\mathrm{Co} / \mathrm{Al}_{2} \mathrm{O}_{3}$ catalysts during aqueous-phase FTS at $438 \mathrm{~K}$ and found that the selectivity for hydrocarbons $\left(\mathrm{C}_{2+}\right)$ is high at the value of $84.5 \%$ followed by oxygenates $9.2 \%$, whilst methane is only $4 \%$ on the un-promoted $25 \% \mathrm{Co} / \mathrm{Al}_{2} \mathrm{O}_{3}$ catalysts. It was proved that alkali metal-modified unsupported and supported cobalt worked efficiently for the production of oxygenates by Ishida and co-workers. ${ }^{103}$ Product distributions were obtained by $\mathrm{Co} / \mathrm{SiO}_{2}$ and $\mathrm{NaCo} / \mathrm{SiO}_{2}$ catalysts at 518 $\mathrm{K}$. It was found that methanol is the major products in the alcohol distributions by $\mathrm{Co} / \mathrm{SiO}_{2}$ and with the added sodium, the higher alcohol selectivity was exhibited. ${ }^{103}$

The selectivity of $\mathrm{CH}_{4}$ decreases from $425 \mathrm{~K}$ to $475 \mathrm{~K}$ as the selectivity of $\mathrm{C}_{2} \mathrm{H}_{4}$ is increased at $425 \mathrm{~K}$ to $525 \mathrm{~K}$ whilst the selectivity of $\mathrm{CH}_{3} \mathrm{OH}$ still remains high at $475 \mathrm{~K}$. From $475 \mathrm{~K}$ to 525 $\mathrm{K}$, the selectivity of $\mathrm{CH}_{4}$ increases slightly. From $525 \mathrm{~K}$ to $700 \mathrm{~K}$, the selectivity of $\mathrm{C}_{2} \mathrm{H}_{4}$ decreases dramatically and the selectivity of $\mathrm{CH}_{4}$ increases remarkably. 


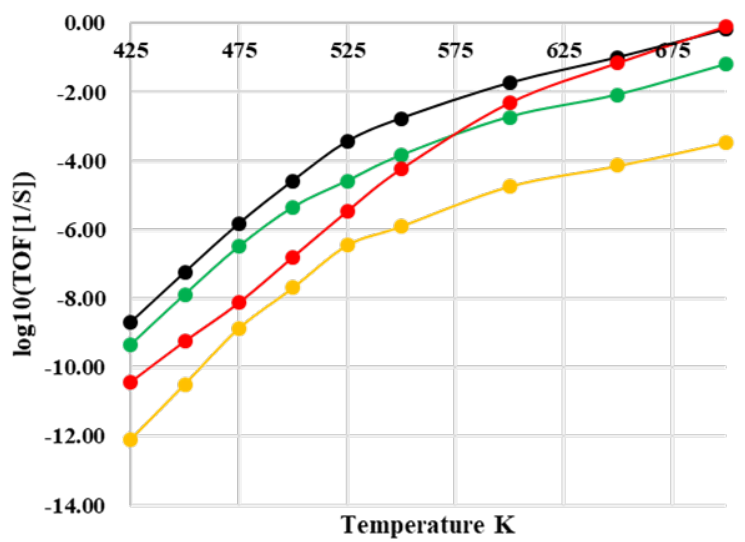

(a) $\rightarrow$ - 2 H4 $\rightarrow-\mathrm{CH} 3 \mathrm{OH} \rightarrow \mathrm{CH}_{4} \rightarrow-\mathrm{C} 2 \mathrm{H} 6$

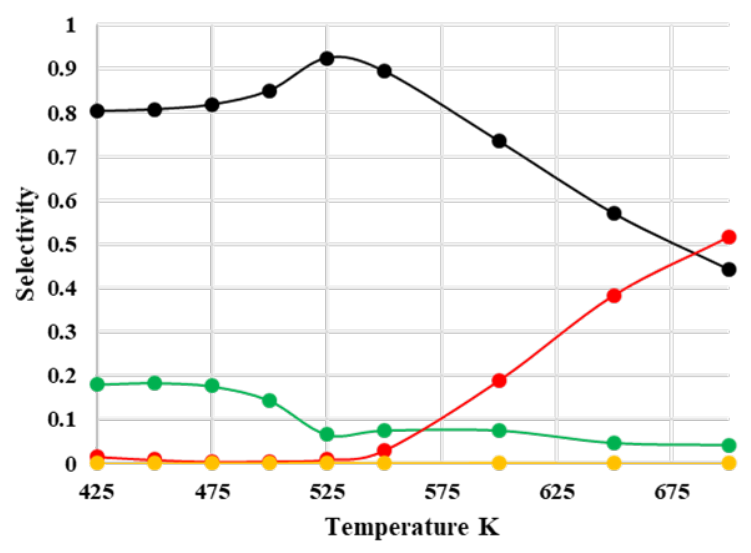

(b) $\rightarrow-\mathrm{C}_{2} 4 \rightarrow-\mathrm{CH} 3 \mathrm{OH} \rightarrow \mathrm{CH}_{4} \rightarrow-\mathrm{C} 2 \mathrm{H} 6$

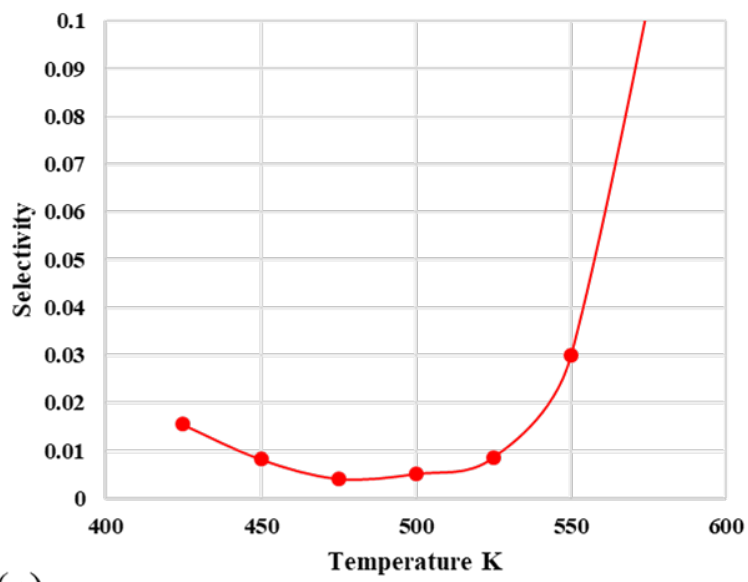

(c)

Figure 11. (a) Turnover frequencies and (b) selectivity for $\mathrm{C}_{2} \mathrm{H}_{4}, \mathrm{CH}_{3} \mathrm{OH}, \mathrm{CH}_{4}, \mathrm{C}_{2} \mathrm{H}_{6}$ using coverage dependent model on flat $\mathrm{Co}(0001)$ from $425 \mathrm{~K}$ to $700 \mathrm{~K}$. (c) Selectivity for $\mathrm{CH}_{4}$ from $425 \mathrm{~K}$ to $575 \mathrm{~K}$. 


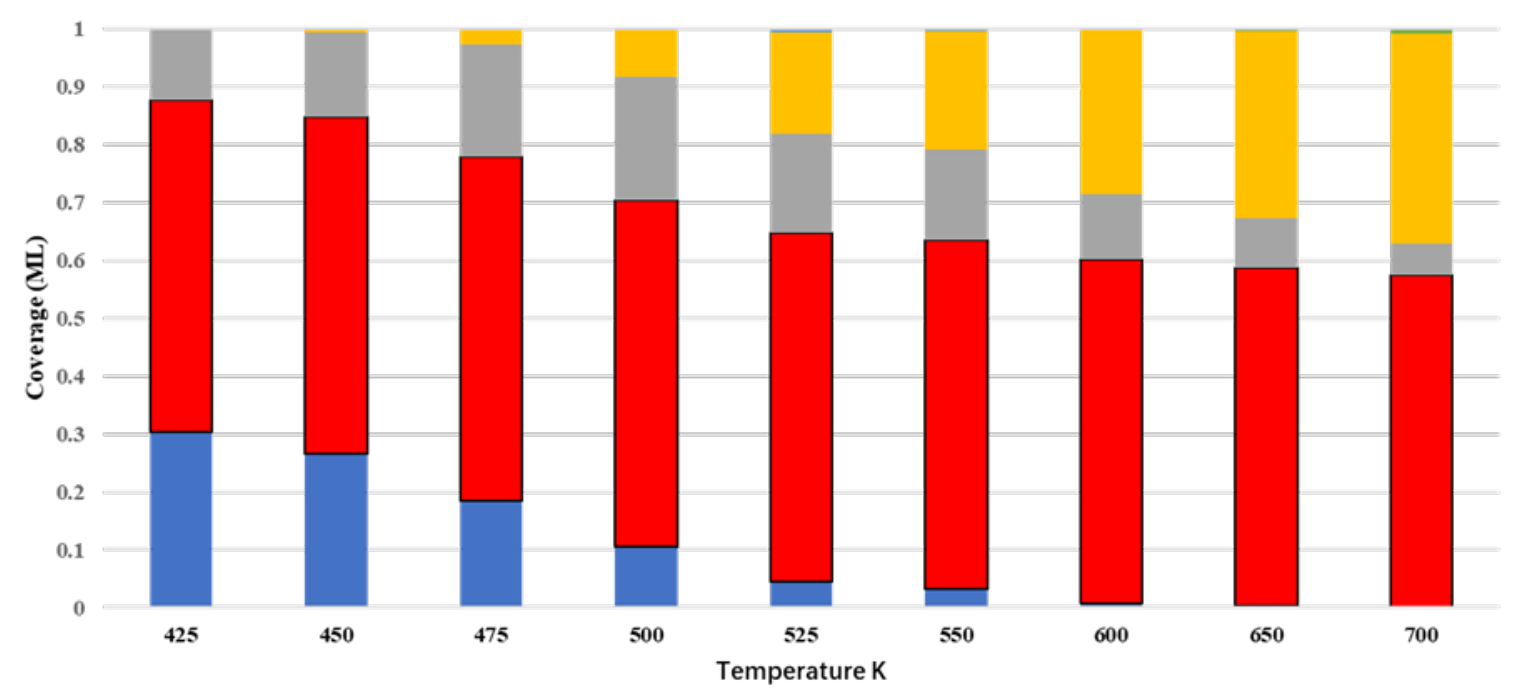

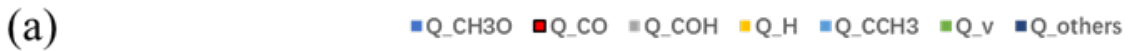

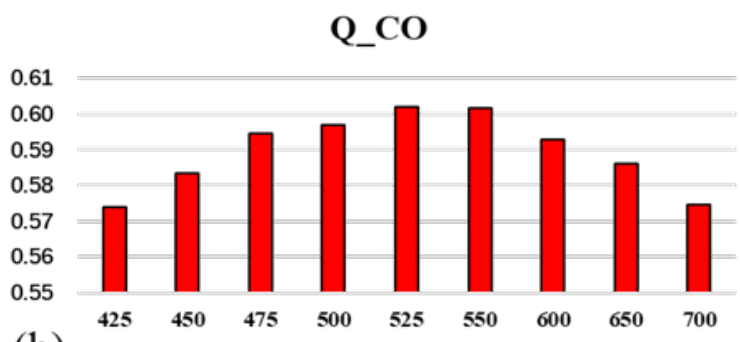

(b)

\section{Q_CH3O}
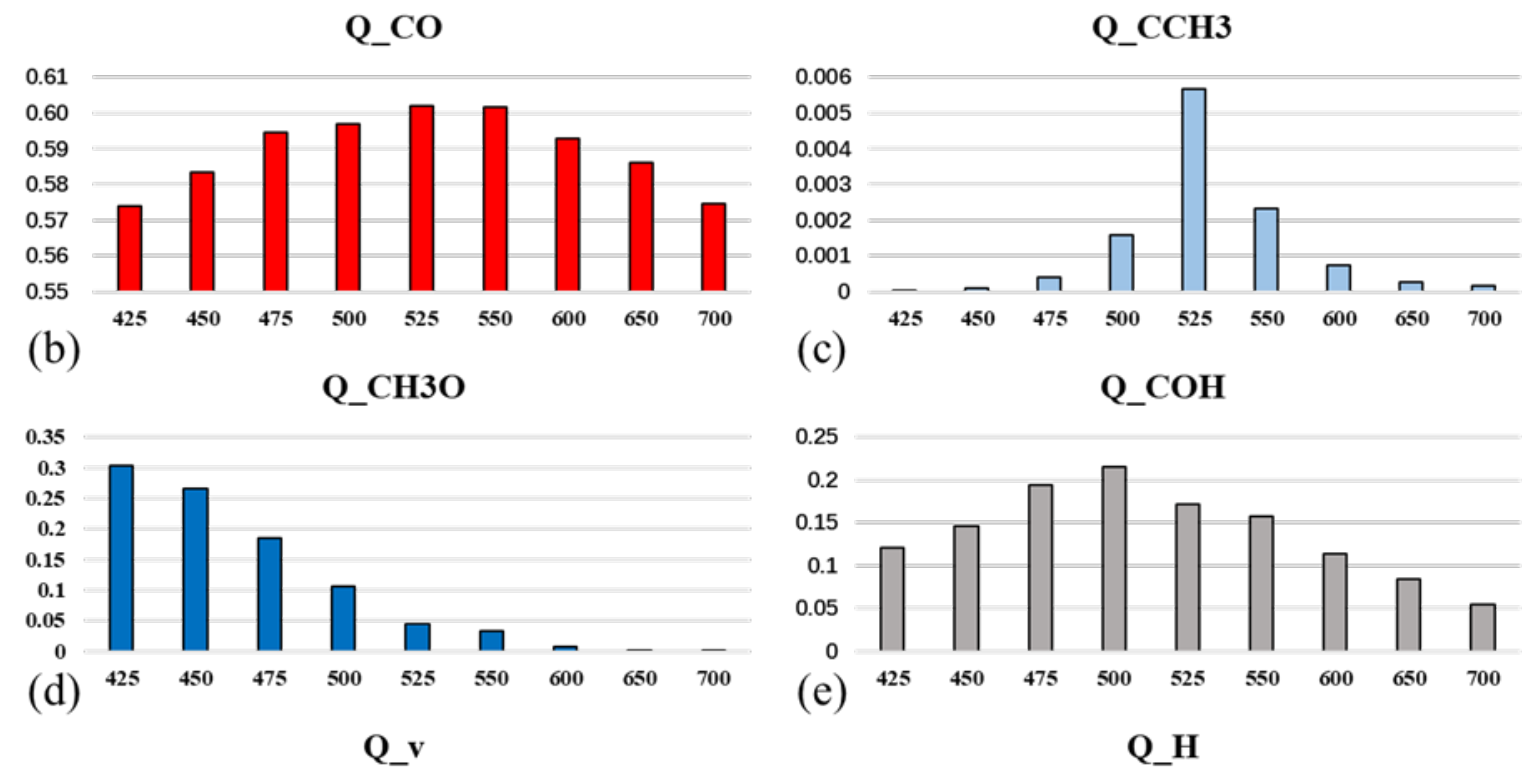

(c)
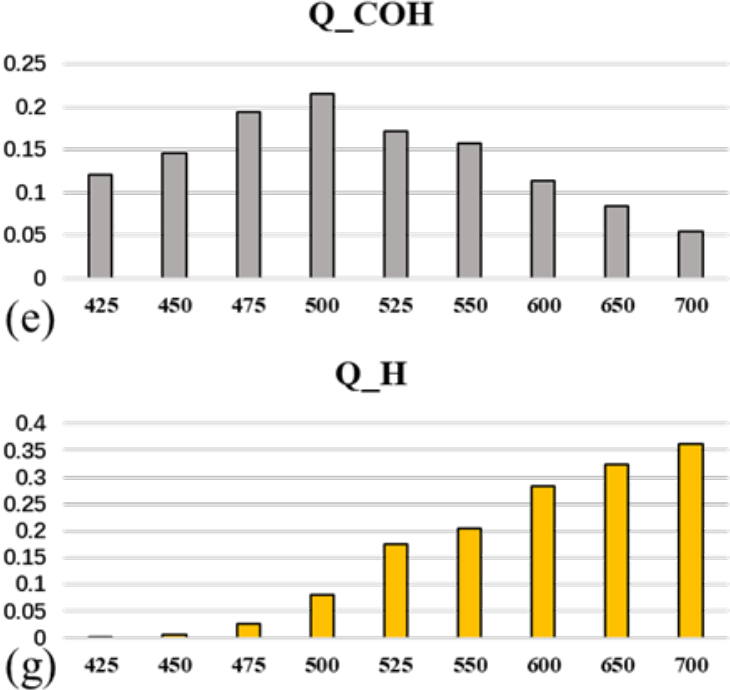

Figure 12. (a) Proportions of main species coverage from $425 \mathrm{~K}$ to $700 \mathrm{~K}$. Blue is $\mathrm{CH}_{3} \mathrm{O}$, $\mathrm{Red}$ is $\mathrm{CO}$, grey is $\mathrm{COH}$, yellow is $\mathrm{H}$, light blue is $\mathrm{CCH}_{3}$, and green is vacancy. (b) Coverage of $\mathrm{CO}$ from $425 \mathrm{~K}$ to $700 \mathrm{~K}$. (c) Coverage of $\mathrm{CCH}_{3}$ from $425 \mathrm{~K}$ to $700 \mathrm{~K}$. (d) Coverage of $\mathrm{CH}_{3} \mathrm{O}$ from $425 \mathrm{~K}$ to $700 \mathrm{~K}$. (e) Coverage of $\mathrm{COH}$ from $425 \mathrm{~K}$ to $700 \mathrm{~K}$. (f) Coverage of vacancy from $425 \mathrm{~K}$ to 700 K. (g) Coverage of $\mathrm{H}$ from $425 \mathrm{~K}$ to $700 \mathrm{~K}$. 


\subsection{Temperature Effects on the Olefin/Paraffin Ratio from the Coverage-dependence Kinetic Modelling}

FT reactions on cobalt-catalysts are typically carried out at the low temperatures ( $473 \mathrm{~K}$ to 513 $\mathrm{K}){ }^{104} \mathrm{We}$ used the ratio of olefin/paraffin $\left(\frac{\mathrm{CH}_{2} \mathrm{CH}_{2}}{\mathrm{CH}_{4}+\mathrm{CH}_{3} \mathrm{CH}_{3}}\right)$ to characterize the selectivity towards olefin production. $\alpha$-olefin can re-adsorb onto the surface and be hydrogenated to produce paraffin or reinsert into hydrocarbons. Improving the selectivity towards olefins will obtain great economic benefits from FT reactions and it is a hot topic of research on how to increase the ratio of olefin to paraffin..$^{72,105-111}$ Our results indicate that the peak of the ratio of olefin/paraffin ratio is around the temperature of $475 \mathrm{~K}$, which is displayed in Figure 13. It is noticed that $475 \mathrm{~K}$ is very close to the typically used temperature range. When the temperature is in the range from $475 \mathrm{~K}$ to $513 \mathrm{~K}$, it can still maintain a high ratio of olefin/paraffin. The higher temperature will, however, lead to a lower ratio of olefin/paraffin due to the higher selectivity of methane.

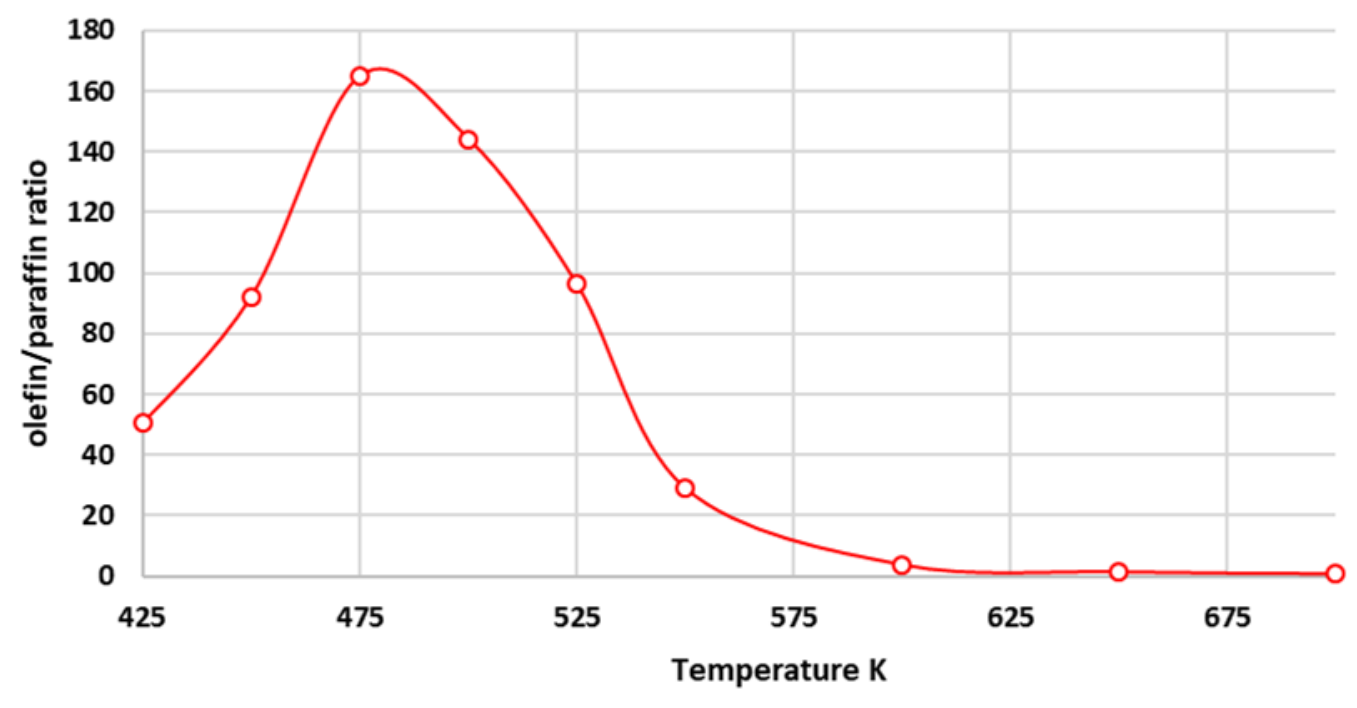

Figure 13. The ratio of olefin/paraffin from $425 \mathrm{~K}$ to $700 \mathrm{~K}$.

\subsection{Analysis of Degree of Rate Control from $425 \mathrm{~K}$ to $700 \mathrm{~K}$}

In this section, we will further discuss the complicated reaction pathways to elucidate the ratedetermining step controlling the activity and selectivity of the FT process on the flat $\operatorname{Co}(0001)$ surface with respect to the temperature. Thanks to the concept of degree of rate control from 
Campbell et al., ${ }^{62-65}$ we used this approach to analyze the microkinetic modelling results. The application of degree of rate control can be used to evaluate the elementary reaction step affecting the net reaction rate as follows:

$\mathrm{X}_{\mathrm{DRC}, \mathrm{i}}=\frac{\mathrm{k}_{\mathrm{i}}}{\mathrm{r}}\left(\frac{\partial \mathrm{r}}{\partial \mathrm{k}_{\mathrm{i}}}\right)_{\mathrm{k}_{\mathrm{j} \neq \mathrm{i}, \mathrm{K}_{\mathrm{i}}}}=\left(\frac{\partial \ln \mathrm{r}}{\partial \ln \mathrm{k}_{\mathrm{i}}}\right)_{\mathrm{k}_{j \neq i, \mathrm{~K}_{\mathrm{i}}}}$

where $X_{\mathrm{DRC}, i}$ is the relative derivative in the net rate per relative derivative in the rate constant for step $i, k_{i}$ is the rate constant of elementary step $i, r$ is the net reaction rate for the specific reactants or products we want to investigate and under the condition that fixes the values of other rate constants $k_{j}$ and the equilibrium constant $K_{i}$. The larger the numeric value of $X_{D R C, i}$ is for a given step, the bigger the influence of its rate constant on the overall reaction rate $r$ is. If a DRC value of the elementary step is positive, decreasing the barrier at this step will increase the TOF of specific reactants or products. A negative value indicates the opposite; such steps are termed as the inhibition steps ${ }^{65}$ In Figure 14, we can see that for each set of DRC coefficients, the sum is equal to unity, which verifies that the microkinetic simulations were properly converged with a satisfactory numerical accuracy.

In the current work, the DRC analyses are carried out for the following key steps: (a) $\mathrm{CO}^{*} \rightarrow$ $\mathrm{CO}^{*}$, (b) $\mathrm{CH}_{2} \mathrm{CH}_{2}{ }^{*} \rightarrow \mathrm{CH}_{2} \mathrm{CH}_{2}+^{*}$, (c) $\mathrm{H}^{*}+\mathrm{CH}_{3}{ }^{*} \rightarrow \mathrm{CH}_{4}+^{*}+^{*}$, (d) $\mathrm{CH}_{3} \mathrm{O}^{*}+\mathrm{H}^{*} \rightarrow \mathrm{CH}_{3} \mathrm{OH}+*+^{*}$, and (e) $\mathrm{CH}_{2} \mathrm{OH}^{*}+\mathrm{H}^{*} \rightarrow \mathrm{CH}_{3} \mathrm{OH}+*+*$, which are shown in the Figure 14 . 


\begin{tabular}{|c|c|c|c|c|c|c|c|c|c|c|}
\hline \multirow{13}{*}{ (a) } & & $425 \mathrm{~K}$ & $450 \mathrm{~K}$ & $475 \mathrm{~K}$ & \multicolumn{3}{|c|}{$500 \mathrm{~K} 525 \mathrm{~K} 550 \mathrm{~K}$} & $600 \mathrm{~K}$ & $650 \mathrm{~K}$ & $700 \mathrm{~K}$ \\
\hline & $\begin{array}{l}\mathrm{CH}_{3} \mathrm{O}^{*}+^{*} \rightleftarrows \mathrm{CH}^{*}+\mathrm{O}^{*} \\
\mathrm{CHOH}^{*}+^{\star} \rightleftarrows \mathrm{CH}^{*}+\mathrm{OH}^{*}\end{array}$ & $\begin{array}{l}0.61 \\
0.22\end{array}$ & 0.52 & 0.53 & $\begin{array}{l}0.44 \\
0.43\end{array}$ & $\begin{array}{l}0.33 \\
0.41\end{array}$ & $\frac{0.27}{0.4}$ & $\begin{array}{l}0.2 \\
0.35\end{array}$ & $\begin{array}{l}0.14 \\
0.39\end{array}$ & $\begin{array}{l}0.1 \\
0.42\end{array}$ \\
\hline & $\mathrm{CO}^{*}+\mathrm{H}^{*} \rightleftarrows \mathrm{CHO}^{*}+^{*}$ & 0.14 & 0.1 & 0.31 & 0.43 & 0.41 & 0.4 & 0.35 & 0.05 & $\begin{array}{l}0.42 \\
0.08\end{array}$ \\
\hline & $\mathrm{CH}_{3} \mathrm{CO}^{*}+* \star \mathrm{CCH}^{*}+\mathrm{O}^{*}$ & 0 & 0 & 0 & 0 & 0.06 & 0.14 & 0.4 & 0.27 & 0.11 \\
\hline & $\mathrm{CH}_{2} \mathrm{O}^{*}+\mathrm{H}^{*} \rightleftarrows \mathrm{CH}_{2} \mathrm{OH}^{*}+^{*}$ & 0.04 & 0.05 & 0.04 & 0.03 & 0.02 & 0.03 & 0.03 & 0.02 & 0.02 \\
\hline & $\mathrm{CH}^{*}+\mathrm{CH}^{*} \rightleftarrows \mathrm{CHCH}^{*}+^{*}$ & 0 & 0 & 0.02 & 0.1 & 0.82 & 0.44 & 0.05 & -0.02 & -0.01 \\
\hline & $\mathrm{H}^{*}+\mathrm{CH}^{* *} \rightleftarrows \mathrm{CH}_{4++^{*}+*}$ & -0.01 & 0 & 0 & 0 & -0.01 & -0.03 & -0.07 & -0.06 & -0.03 \\
\hline & $\mathrm{CO}^{*}+\mathrm{H}^{*} \rightleftarrows \mathrm{COH}^{*}+^{*}$ & -0.01 & 0.01 & -0.01 & 0 & 0.06 & 0.08 & 0.11 & 0.13 & 0.17 \\
\hline & $\mathrm{CHO}^{*}+{ }^{*} \rightleftarrows \mathrm{CH}^{*}+\mathrm{O}^{*}$ & 0 & 0.01 & 0.01 & 0.02 & 0.03 & 0.04 & 0.06 & 0.13 & 0.16 \\
\hline & $\mathrm{CHO}^{*}+\mathrm{H}^{*} \rightleftarrows \mathrm{CHOH}^{*}+^{*}$ & -0.03 & -0.01 & -0.05 & 0 & 0.08 & 0.07 & 0.03 & 0.02 & 0 \\
\hline & $\mathrm{CH} 3 \mathrm{O}^{*}+\mathrm{H}^{*} \rightleftharpoons \mathrm{CH} 3 \mathrm{OH}++^{*}+^{*}$ & 0.03 & 0.03 & 0.05 & 0.04 & 0.02 & 0.01 & 0 & 0 & 0 \\
\hline & $\mathrm{CHCH}_{2}^{*}+\mathrm{H}^{\star} \rightleftarrows \mathrm{CH}_{2} \mathrm{CH}_{2} 2^{*}+$ & 0 & 0 & -0.01 & -0.06 & -0.56 & -0.39 & -0.16 & -0.07 & -0.02 \\
\hline & $\mathrm{CHCH}^{*}+\mathrm{H}^{*} \rightleftarrows \mathrm{CH}_{2} \mathrm{CH}^{*}+^{*}$ & 0 & 0 & -0.01 & -0.01 & -0.03 & -0.03 & -0.02 & -0.01 & 0 \\
\hline & $\mathrm{CH} 3 \mathrm{O}^{*}+{ }^{\star} \rightleftarrows \mathrm{CH}_{3}^{*}+$ & 0.69 & 0.59 & 59 & 0.48 & 0.35 & 0.29 & 0.22 & 0.16 & 0.12 \\
\hline (b) & $\mathrm{CHOH}^{*}+^{\star} \rightleftarrows \mathrm{CH}^{*}+\mathrm{OH}^{*}$ & 0.23 & 0.30 & 0.38 & 0.44 & 0.41 & 0.41 & 0.37 & 0.44 & 0.52 \\
\hline & $\mathrm{CO}^{*}+\mathrm{H}^{\star} \rightleftarrows \mathrm{CHO}^{*}+^{\star}$ & 0.14 & 0.10 & 0.06 & 0.03 & 0.01 & 0.02 & 0.04 & 0.06 & 0.09 \\
\hline & $\mathrm{CH}^{*}+\mathrm{CH}^{*} \rightleftarrows \mathrm{CHCH}^{*}+^{*}$ & 0.00 & 0.00 & 0.02 & 0.11 & 0.85 & 0.46 & 0.04 & 0.00 & 0.05 \\
\hline & $\mathrm{CH}^{3} \mathrm{CO}^{*}+{ }^{\star} \rightleftharpoons \mathrm{CCH}^{*}+\mathrm{O}^{*}$ & 0.00 & 0.00 & 0.00 & 0.01 & 0.06 & 0.16 & 0.49 & 0.38 & 0.17 \\
\hline & $\mathrm{CO}^{*}+\mathrm{H}^{*} \rightleftarrows \mathrm{COH}^{*}+^{*}$ & -0.01 & 0.01 & 0.00 & 0.01 & 0.07 & 0.09 & 0.12 & 0.15 & 0.21 \\
\hline & $\mathrm{CHO}^{*}+^{*} \rightleftarrows \mathrm{CH}^{*}+\mathrm{O}^{*}$ & 0.00 & 0.01 & 0.01 & 0.02 & 0.03 & 0.04 & 0.07 & 0.15 & 0.20 \\
\hline & $\mathrm{CH}_{2} \mathrm{CH}_{2}{ }^{*}+\mathrm{H}^{*} \rightleftarrows \mathrm{CH}_{2} \mathrm{CH}_{3} 3^{*}$ & 0.00 & 0.00 & -0.02 & -0.07 & -0.45 & -0.19 & -0.04 & 0.00 & 0.00 \\
\hline & $\mathrm{CHCH}_{2} 2^{*}+\mathrm{H}^{*} \rightleftarrows \mathrm{CH}_{2} \mathrm{CH}_{2} 2^{*}$ & 0.00 & 0.00 & -0.01 & -0.06 & -0.58 & -0.40 & -0.14 & -0.01 & 0.08 \\
\hline & $\mathrm{H}^{*}+\mathrm{CH}_{3}{ }^{*} \rightleftarrows \mathrm{CH}_{4+*}^{*}+^{*}$ & 0.98 & 0.99 & 99 & 0.99 & 0.98 & 0.95 & 0.84 & 0.78 & 74 \\
\hline (c) & $\mathrm{CH} 0^{*}++^{*} \rightleftarrows \mathrm{CH}^{* *}+\mathrm{O}^{*}$ & 0.86 & 0.84 & 0.72 & 0.54 & 0.35 & 0.28 & 0.17 & 0.11 & 0.07 \\
\hline & $\mathrm{CO}^{*}+\mathrm{H}^{*} \rightleftharpoons \mathrm{CHO}^{*}+^{*}$ & 0.19 & 0.14 & 0.07 & 0.03 & 0.01 & 0.02 & 0.03 & 0.03 & 0.05 \\
\hline & $\mathrm{CHOH}^{*}+^{\star} \rightleftarrows \mathrm{CH}^{*}+\mathrm{OH}^{\star}$ & 0.17 & 0.22 & 0.34 & 0.42 & 0.41 & 0.40 & 0.31 & 0.30 & 0.30 \\
\hline & $\mathrm{CO}^{*}+\mathrm{H}^{*} \rightleftarrows \mathrm{COH}^{*}+^{\star}$ & -0.07 & -0.04 & -0.03 & 0.00 & 0.06 & 0.08 & 0.07 & 0.08 & 0.10 \\
\hline & $\mathrm{CH}^{3 *}+\mathrm{CO}^{*} \rightleftarrows \mathrm{CH}_{3} \mathrm{CO}^{*}+^{*}$ & -0.16 & -0.05 & -0.01 & 0.00 & 0.00 & 0.00 & 0.00 & 0.00 & 0.00 \\
\hline & $\mathrm{H}^{*}+\mathrm{CH}^{2}$ & -0.77 & -0.71 & -0.35 & -0.12 & -0.01 & -0.01 & 0.00 & 0.00 & 0.01 \\
\hline & $=\mathrm{CHCH}^{*} \star^{*}$ & 0.00 & 0.00 & 0.03 & 0.17 & 1.10 & 0.66 & 0.09 & -0.07 & -0.12 \\
\hline & $\mathrm{CH}^{*}+\mathrm{CH}^{2}{ }^{*} \rightleftarrows \mathrm{CHCH}_{2^{*}+{ }^{*}}$ & 0.00 & 0.00 & 0.01 & 0.04 & 0.21 & 0.11 & 0.02 & -0.01 & -0.02 \\
\hline & $\mathrm{CHO}^{*}$ & 0.00 & 0.00 & 0.01 & 0.02 & 0.03 & 0.04 & 0.05 & 0.09 & 0.11 \\
\hline & $\mathrm{CH}_{2} \mathrm{CH}_{2}{ }^{*}+\mathrm{H}^{*} \rightleftharpoons \mathrm{CH}_{2} \mathrm{CH}^{3}+^{*}$ & 0.00 & 0.00 & -0.02 & -0.11 & -0.59 & -0.27 & -0.10 & -0.03 & -0.01 \\
\hline & $\mathrm{CHCH}_{2} 2^{*}+\mathrm{H}^{*} \rightleftarrows \mathrm{CH}_{2} \mathrm{CH}_{2} 2^{*}{ }^{*}$ & 0.00 & 0.00 & -0.01 & -0.10 & -0.76 & -0.58 & -0.32 & -0.25 & -0.20 \\
\hline & $\mathrm{CH}{ }^{3} \mathrm{CO}^{*}+* * \mathrm{CCH}^{3 *}+\mathrm{O}^{*}$ & -0.04 & -0.18 & -0.44 & -0.61 & -0.70 & -0.66 & -0.15 & -0.02 & 0.00 \\
\hline & $\mathrm{CH} 3 \mathrm{O}$ & & 0.99 & & 1 & 1 & 1 & 1 & 1 & 1 \\
\hline (d) & $\mathrm{CHOH}^{*}+{ }^{*} \rightleftarrows \mathrm{CH}^{*}+\mathrm{OH}^{*}$ & 0.17 & 0.2 & 0.27 & 0.3 & 0.23 & 0.19 & 0.1 & 0.04 & 0.01 \\
\hline (a) & $\mathrm{CO}^{*}+\mathrm{H}^{*} \rightleftarrows \mathrm{CHO}^{*}+^{*}$ & 0.2 & 0.15 & 0.08 & 0.04 & 0.02 & 0.04 & 0.09 & 0.12 & 0.19 \\
\hline & $\mathrm{CHO}^{*}$ & -0.12 & -0.17 & -0.22 & -0.2 & -0.15 & -0.11 & -0.05 & -0.04 & -0.02 \\
\hline & $\mathrm{CO}^{*}+\mathrm{H}$ & -0.07 & -0.06 & -0.07 & -0.12 & -0.1 & -0.1 & -0.08 & -0.04 & -0.01 \\
\hline & $\mathrm{CH}_{3} \mathrm{O}$ & & & & & & & & & \\
\hline & $\mathrm{CHO}^{*}$ & $\frac{.98}{-0.12}$ & 0.96 & $\frac{0.0 y}{-0.22}$ & $\frac{0.96}{-0.2}$ & $\frac{0.96}{-0.14}$ & $\frac{0.96}{-0.11}$ & $\frac{0.96}{-0.05}$ & $\frac{0.95}{-0.03}$ & $\frac{0.93}{-0.02}$ \\
\hline (e) & $\mathrm{CHOH}^{*}+^{*} \rightleftarrows \mathrm{CH}^{*}+\mathrm{OH}^{*}$ & 0.17 & 0.2 & 0.27 & 0.3 & 0.23 & 0.19 & 0.1 & 0.03 & -0.01 \\
\hline & $\mathrm{CO}^{*}+\mathrm{H}^{*} \rightleftarrows \mathrm{CHO}^{*}+^{*}$ & 0.19 & 0.15 & 0.08 & 0.04 & 0.02 & 0.04 & 0.09 & 0.11 & 0.18 \\
\hline
\end{tabular}

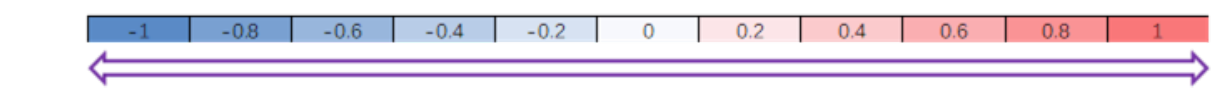

Negative DRC

Positive DRC

Figure 14. Degrees of rate control from the elementary steps on $\mathrm{CO}^{*} \rightarrow \mathrm{CO}^{*}$ (a); those on $\mathrm{CH}_{2} \mathrm{CH}_{2}{ }^{*} \rightarrow \mathrm{CH}_{2} \mathrm{CH}_{2}+^{*}$ (b); those on $\mathrm{H}^{*}+\mathrm{CH}_{3} * \rightarrow \mathrm{CH}_{4}+^{*}+^{*}$ (c); those on $\mathrm{CH}_{3} \mathrm{O}^{*}+\mathrm{H}^{*} \rightarrow$ $\mathrm{CH}_{3} \mathrm{OH}+*+*$ (d); and those on $\mathrm{CH}_{2} \mathrm{OH}^{*}+\mathrm{H}^{*} \rightarrow \mathrm{CH}_{3} \mathrm{OH}+*+*$ (e) on $\mathrm{Co}(0001)$. Only elementary steps that are important are displayed and some values that are deemed to be too small to have a significant effect are not included. For example, only the steps that affect considerably $\mathrm{CO}^{*} \rightarrow$ CO* are shown in (a).

Our results show that the whole temperature region can be divided into three specific regions: low temperature region $(425 \mathrm{~K} \leq \mathrm{T}<500 \mathrm{~K})$; medium temperature $(500 \mathrm{~K} \leq \mathrm{T}<600 \mathrm{~K})$; and high 
temperature $(600 \mathrm{~K} \leq \mathrm{T}<700 \mathrm{~K})$. We first used our coverage-dependent model to analyse the reaction network for the elementary step of $\mathrm{CO}^{*} \rightarrow \mathrm{CO} *$ (Figure 14(a)) in low temperature region $(425 \mathrm{~K} \leq \mathrm{T}<500 \mathrm{~K})$. Three elementary reaction steps can considerably affect the step of $\mathrm{CO}{ }^{*}$ $\rightarrow \mathrm{CO} *$ (Figure 14(a)), and the order to their importance is as follows: $\mathrm{CH}_{3} \mathrm{O}^{*}+* \rightarrow \mathrm{CH}_{3}{ }^{*}+\mathrm{O}^{*}>$ $\mathrm{CHOH}^{*}+\rightarrow \mathrm{CH}^{*}+\mathrm{OH}^{*}>\mathrm{CO}^{*}+\mathrm{H}^{*} \rightarrow \mathrm{CHO}^{*}+$. All the values for the DRC are positive, meaning that $\mathrm{CO}$ adsorption will increase if the barriers of these three reactions are decreased.

Overall, a low temperature leads to a low total TOF of $\mathrm{CO}$ consumption. When the temperature is increased to a medium temperature $(500 \mathrm{~K} \leq \mathrm{T}<600 \mathrm{~K})$, the DRC value of the elementary step of $\mathrm{CHOH}^{*}+* \mathrm{CH}^{*}+\mathrm{OH}^{*}$ slightly decreases from 0.43 to 0.33 , while the DRC value of the elementary step $\mathrm{CH}_{3} \mathrm{O}^{*}+* \rightarrow \mathrm{CH}_{3} *+\mathrm{O}^{*}$ is dramatically decreased. Importantly, the DRC value of $\mathrm{CHCH}^{*}+* \rightarrow \mathrm{CH}^{*}+\mathrm{CH}^{*}$ increases dramatically to 0.82 at $525 \mathrm{~K}$. It indicates that if the bond breaking barrier of $\mathrm{CH}-\mathrm{CH}$ is decreased, it will result in more $\mathrm{CH}$ monomers, promoting the $\mathrm{CO}$ insertion mechanism. When the temperature is raised to high temperatures $(600 \mathrm{~K} \leq \mathrm{T} \leq 700 \mathrm{~K})$, the DRC value of $\mathrm{CHOH}^{*}+* \rightarrow \mathrm{CH}^{*}+\mathrm{OH}^{*}$ still maintains a high level of approximately 0.38 compared other pathways. The DRC value of the elementary step of $\mathrm{CH}_{3} \mathrm{O}^{*}+* \rightarrow \mathrm{CH}_{3}{ }^{*}+\mathrm{O}^{*}$ is at a low level. Other elementary steps have a less significant effect on the $\mathrm{CO}$ consumption.

The DRC values of elementary steps of (b) $\mathrm{CH}_{2} \mathrm{CH}_{2}{ }^{*} \rightarrow \mathrm{CH}_{2} \mathrm{CH}_{2}+*$ are similar with that of (a) $\mathrm{CO}^{*} \rightarrow \mathrm{CO}^{*}$, illustrated in Figure 14. Interestingly, the DRC value of the elementary step $\mathrm{CH}_{3} \mathrm{CO}^{*}+* \rightarrow \mathrm{CCH}_{3} *+\mathrm{O}^{*}$ increases significantly from $525 \mathrm{~K}$ to $600 \mathrm{~K}$. It can be understood as follows: Decreasing the barrier of $\mathrm{CH}_{3} \mathrm{CO}^{*}+* \rightarrow \mathrm{CCH}_{3}{ }^{*}+\mathrm{O}^{*}$ will increase the coverage of $\mathrm{CCH}_{3}$ and the high coverage of $\mathrm{CCH}_{3}$ means the high selectivity towards $\mathrm{C}_{2}$ species, which has been discussed in section 4.1.

Regarding the selectivity of methane (Figure14 (c)), when the temperature is in the low temperature region $(425 \mathrm{~K} \leq \mathrm{T}<500 \mathrm{~K})$, three elementary reaction steps, $\mathrm{H}^{*}+\mathrm{CH}_{3} * \rightarrow \mathrm{CH}_{4}+^{*}+*$, $\mathrm{CH}_{3} \mathrm{O}^{*}+* \rightarrow \mathrm{CH}_{3}{ }^{*}+\mathrm{O}^{*}$ and $\mathrm{CH}_{3}{ }^{*}{ }^{*} \rightarrow \mathrm{H}^{*}+\mathrm{CH}_{2}{ }^{*}$, can considerably affect the methane formation. A barrier decreases of $\mathrm{H}^{*}+\mathrm{CH}_{3} * \rightarrow \mathrm{CH}_{4}{ }^{*}+*$ will facilitate the consumption of $\mathrm{CH}_{3}$, whilst reducing the barrier of $\mathrm{CH}_{3} \mathrm{O}^{*}+* \rightarrow \mathrm{CH}_{3}{ }^{*}+\mathrm{O}^{*}$ will increase the formation of $\mathrm{CH}_{3}$. It is worth mentioning that $\mathrm{CH}_{3}$ can readily dissociate into $\mathrm{CH}_{2}$ and $\mathrm{H}$; if equilibrium is reached under the reaction condition, increasing the barrier of $\mathrm{CH}_{2}-\mathrm{H}$ bond breaking will inhibit the formation of $\mathrm{CH}_{2}$, and the selectivity of $\mathrm{C}_{2}$ formation will decrease. When the temperature rises to a medium temperature $(500 \mathrm{~K} \leq \mathrm{T}<600 \mathrm{~K})$, the selectivity of $\mathrm{CH}_{4}$ is dramatically increased. The DRC value 
of the elementary step $\mathrm{H}^{*}+\mathrm{CH}_{3} * \rightarrow \mathrm{CH}_{4}+^{*}+*$ remains at a high value around 0.98 . The DRC value of the elementary step of $\mathrm{CH}_{3} \mathrm{O}^{*}+* \rightarrow \mathrm{CH}_{3}{ }^{*}+\mathrm{O}^{*}$ decreases quickly from the low temperature region to the medium temperature region as high temperatures lead to lower coverages of $\mathrm{CH}_{3} \mathrm{O}$ on the surface and the rate of $\mathrm{CH}_{3} \mathrm{O}$ dissociation increases at the higher temperatures. The DRC analyses also show that decreasing the barriers of the elementary steps $\mathrm{CHOH}^{*}{ }^{*} \rightarrow \mathrm{CH}^{*}+\mathrm{OH}^{*}$, and $\mathrm{CHCH}^{*}+* \mathrm{CH}^{*}+\mathrm{CH}^{*}$ will facilitate the formation of $\mathrm{CH}$. The negative DRC values associated with the elementary steps of $\mathrm{CH}_{2} \mathrm{CH}_{3} *+* \rightarrow \mathrm{CH}_{2} \mathrm{CH}_{2} *+\mathrm{H}^{*}, \mathrm{CHCH}_{2} *+\mathrm{H}^{*} \rightarrow$ $\mathrm{CH}_{2} \mathrm{CH}_{2}{ }^{*}{ }^{*}$, and $\mathrm{CH}_{3} \mathrm{CO}^{*}+^{*} \rightarrow \mathrm{CCH}_{3}{ }^{*}+\mathrm{O}^{*}$, means that if we decrease their barriers, the selectivity of $\mathrm{CH}_{2} \mathrm{CH}_{2}$ will increase and the selectivity of $\mathrm{CH}_{4}$ will decrease. When the temperature increases further $(600 \mathrm{~K} \leq \mathrm{T} \leq 700 \mathrm{~K})$, the DRC value of the elementary step $\mathrm{H}^{*}+\mathrm{CH}_{3}{ }^{*} \rightarrow$ $\mathrm{CH}_{4}+^{*}+*$ remains high at approximately 0.78 .

For elementary step (d), $\mathrm{CH}_{3} \mathrm{O}^{*}+\mathrm{H}^{*} \rightarrow \mathrm{CH}_{3} \mathrm{OH}+*+*$ in Figure 14, its positive DRC value is nearly a constant regardless of the change of temperature. Similarly, for elementary step (e), $\mathrm{CH}_{2} \mathrm{OH}^{*}+\mathrm{H}^{*} \rightarrow \mathrm{CH}_{3} \mathrm{OH}+*+*$, the yield of $\mathrm{CH}_{3} \mathrm{OH}$ is predominantly controlled by the barrier of $\mathrm{CH}_{2} \mathrm{O}-\mathrm{H}$ bond formation.

\section{CONCLUSION}

This work represents one of the first attempts to use the non-coverage dependent model and coverage dependent model with DFT-D3 functional energy data to investigate activity and selectivity of FT synthesis with respect to temperature on $\operatorname{Co}(0001)$. The following conclusions have been reached:

(i) The total consumption of $\mathrm{CO}$ rate at $500 \mathrm{~K}$ was calculated to be in the order of $10^{-5} \mathrm{~s}^{-1}$ from the coverage dependent model. This was much higher than the result for the non-coverage dependent model which is in the order of $10^{-11} \mathrm{~s}^{-1}$. Our results show that the formation of methane on $\mathrm{Co}(0001)$ is low and the presence of defect sites is a major cause of increasing the selectivity towards methane and a higher total TOF.

(ii) Our kinetic simulations from the coverage dependent model show that the rapid $\mathrm{CO}$ dissociation is difficult on the flat $\mathrm{Co}(0001)$ leading to monomers $\mathrm{CH}_{\mathrm{x}}$ being unable to occupy enough surface sites and carbide mechanism being significantly inhibited. The reaction pathway through $\mathrm{CO}+\mathrm{H} \rightarrow \mathrm{CHO}, \mathrm{CHO}+\mathrm{H} \rightarrow \mathrm{CHOH}, \mathrm{CHOH} \rightarrow \mathrm{CH}+\mathrm{OH}$ is the main pathway to form monomer $\mathrm{CH}$. 
(iii) The $\mathrm{CO}$ insertion mechanism is the dominant mechanism on the flat $\mathrm{Co}(0001)$ surface from both models. The chain growth mechanism is found to be as follows: $\mathrm{CO}$ is inserted into $\mathrm{CR}$ or CHR first, and then after forming $\mathrm{RCH}_{2} \mathrm{CO}$, the $\mathrm{C}-\mathrm{O}$ bond is broken to form the intermediate species $\mathrm{RCH}_{2} \mathrm{C}$. After several hydrogenation or dehydrogenation steps, olefins and paraffins are produced.

(iv) Temperature can affect the surface coverage and the total reaction rate, leading to different selectivities. The kinetic simulations from the coverage dependent model show that the selectivity of oxygenate is high compared to that of methane at low temperatures. From $475 \mathrm{~K}$ to $525 \mathrm{~K}$, the selectivity towards $\mathrm{CH}_{4}$ increases. From $525 \mathrm{~K}$ to $700 \mathrm{~K}$, the selectivity towards $\mathrm{C}_{2}$ decreases significantly and the selectivity towards $\mathrm{CH}_{4}$ increases remarkably.

(v) The simulations from the coverage dependent model show that the peak of the ratio of olefin/paraffin ratio is around the temperature of $475 \mathrm{~K}$. This temperature is very close to typical optimal conditions of $473 \mathrm{~K}$ to $513 \mathrm{~K}$. When the temperature shifts to $513 \mathrm{~K}$, it can still maintain a high ratio of olefin/paraffin. When the temperature is higher than $525 \mathrm{~K}$, our simulations predict that the selectivity towards $\mathrm{CH}_{4}$ increases significantly. Our calculations also show that the temperature should not be too low or too high; low temperatures mean low activity and high selectivity towards long chain hydrocarbons and oxygenates, while high temperatures lead to high selectivity of methane.

\section{ASSOCIATED CONTENT}

\section{AUTHOR INFORMATION}

\section{Corresponding Author}

*E-mail: p.hu@qub.ac.uk

\section{ORCID}

Zihao Yao: 0000-0001-5259-6609

\section{Notes}

The authors declare no competing financial interests. 


\section{Supporting Information}

Geometries, forward barriers, reaction energies of all elementary reaction steps on flat $\mathrm{Co}(0001)$ from the non-coverage dependent kinetic model and coverage dependent kinetic model.

\section{ACKNOWLEDGMENT}

The authors gratefully acknowledge Queen's University of Belfast and UKCP for providing high performance computing service. Z.Y thanks Queen's University of Belfast for a Ph.D. studentship and providing International PGR Scholarship.

\section{REFERENCES}

(1) Biloen, P.; Sachtler, W. M. H. Mechanism of Hydrocarbon Synthesis over Fischer-Tropsch Catalysts. Adv. Catal. 1981, 30, 165-216.

(2) Dry, M.E. Practical and theoretical aspects of the catalytic Fischer-Tropsch process. Appl. Catal., A 1996, 138, 319-344.

(3) Dry, M. E. The Fischer-Tropsch process: 1950-2000. Catal. Today 2002, 71, 227-241.

(4) Geerlings, J. J. C.; Wilson, J. H.; Kramer, G. J.; Kuipers, H. P. C. E.; Hoek, A.; Huisman, H. M. Fischer-Tropsch technology - from active site to commercial process. Appl.Catal., A 1999, 186, 27-40.

(5) Iglesia, E., Design, synthesis, and use of cobalt-based Fischer-Tropsch synthesis catalysts. Appl. Catal., A 1997, 161, 59-78.

(6) Rofer-DePoorter, C. K. A comprehensive mechanism for the Fischer-Tropsch synthesis. Chem. Rev. 1981, 81, 447-474.

(7) Schulz, H. Short history and present trends of Fischer-Tropsch synthesis. Appl. Catal., A 1999, 186, 3-12.

(8) Chanenchuk, C. A.; Yates, I. C.; Satterfield, C. N. The Fischer-Tropsch Synthesis with a Mechanical Mixture of a Cobalt Catalyst and a Copper-Based Water Gas Shift Catalyst. Energy \& Fuels 1991, 5, 847-855.

(9) Geerlings, J. J. C.; Zonnevylle, M. C.; de Groot, C. P. M. Studies of the Fischer-Tropsch reaction on Co(0001). Surf. Sci. 1991, 241, 302-314.

(10) Iglesia, E. Synthesis and Catalytic Properties of Eggshell Cobalt Catalysts for the FischerTropsch Synthesis. J. Catal. 1995, 153, 108-122.

(11) Lahtinen, J.; Anraku, T.; Somorjai, G. A. Carbon Monoxide Hydrogenation on Cobalt Foil and on Thin Cobalt Film Model Catalysts. J. Catal. 1993, 142, 206-225.

(12) Lahtinen, J.; Somorjai, G. A. The effects of promoters in carbon monoxide hydrogenation on cobalt foil model catalysts. J. Mol. Catal. A: Chem. 1998, 130, 255-260.

(13) Lok, C. M. Novel highly dispersed cobalt catalysts for improved Fischer-Tropsch productivity. Stud. Surf. Sci. Catal. 2004, 147, 283-288.

(14) Dictor, R. Fischer-Tropsch synthesis over reduced and unreduced iron oxide catalysts. $J$. Catal. 1986, 97, 121-136.

(15) Ekerdt, J. Evidence for intermediates involved in Fischer-Tropsch synthesis over Ru. $J$. Catal. 1980, 62, 19-25. 
(16) Komaya, T.; Bell, A. Estimates of rate coefficients for elementary processes occurring during Fischer-Tropsch synthesis over Ru/TiO2. J. Catal. 1994, 146, 237-248.

(17) Krishna, K. R.; Bell, A. T. Estimates of the Rate Coefficients for Chain Initiation, Propagation, and Termination during Fischer-Tropsch Synthesis over Ru/TiO2.J. Catal. 1993, 139, 104-118.

(18) Long, H. C.; Turner, M. L.; Fornasiero, P.; Kaspar, J.; Graziani, M.; Maitlis, P. M. Vinylic initiation of the Fischer-Tropsch reaction over ruthenium on silica catalysts. J. Catal. 1997, 167, 172-179.

(19) Maitlis, P. M.; Quyoum, R.; Long, H. C.; Turner, M. L. Towards a chemical understanding of the Fischer-Tropsch reaction: alkene formation. Appl. Catal., A 1999, 186, 363-374.

(20) Ndlovu, S. B.; Phala, N. S.; Hearshaw-Timme, M.; Beagly, P.; Moss, J. R.; Claeys, M.; van Steen, E. Some evidence refuting the alkenyl mechanism for chain growth in iron-based FischerTropsch synthesis. Catal. Today 2002, 71, 343-349.

(21) Bell, A. T. Catalytic Synthesis of Hydrocarbons over Group VIII Metals. A Discussion of the Reaction Mechanism. Cat.Rev. 2006, 23, 203-232.

(22) Hindermann, J. P.; Hutchings, G. J.; Kiennemann, A. Mechanistic Aspects of the Formation of Hydrocarbons and Alcohols from CO Hydrogenation. Cat. Rev. 1993, 35, 1-127.

(23) Ponec, V. Some Aspects of the Mechanism of Methanation and Fischer-Tropsch Synthesis. Cat. Rev. 1978, 18, 151-171.

(24) Van Der Laan, G. P.; Beenackers, A. A. C. M. Kinetics and Selectivity of the FischerTropsch Synthesis: A Literature Review. Cat. Rev. 1999, 41, 255-318.

(25) Chen, W.; Filot, I. A. W.; Pestman, R.; Hensen, E. J. M. Mechanism of Cobalt-Catalyzed CO Hydrogenation: 2. Fischer-Tropsch Synthesis. ACS Catal. 2017, 7, 8061-8071.

(26) Pichler H, S. H. New Insights in the Area of the Synthesis of Hydrocarbons from CO und H2. Chem. Ing. Tech. 1970, 12, 1160.

(27) Scorch, H. H. G., N.; Anderson, R.B. in The Fischer-Tropsch and Related Syntheses. Wiley: New York 1951.

(28) Kummer, J. T.; Emmett, P. H. Fischer-Tropsch Synthesis Mechanism Studies. The Addition of Radioactive Alcohols to the Synthesis Gas. J. Am. Chem. Soc. 1953, 75, 5177-5183.

(29) van Santen, R. A.; Markvoort, A. J.; Filot, I. A.; Ghouri, M. M.; Hensen, E. J. Mechanism and microkinetics of the Fischer-Tropsch reaction. Physical chemistry chemical physics : PCCP 2013, 15, 17038-17063.

(30) Filot, I. A. W.; van Santen, R. A.; Hensen, E. J. M. Quantum chemistry of the FischerTropsch reaction catalysed by a stepped ruthenium surface. Catal. Sci. Technol. 2014, 4, 31293140 .

(31) Banerjee, A.; van Bavel, A. P.; Kuipers, H. P. C. E.; Saeys, M. CO Activation on Realistic Cobalt Surfaces: Kinetic Role of Hydrogen. ACS Catal. 2017, 7, 5289-5293.

(32) Inderwildi, O. R.; Jenkins, S. J.; King, D. A. Mechanistic studies of hydrocarbon combustion and synthesis on noble metals. Angew. Chem. Int. Ed. 2008, 47, 5253-5255.

(33) Inderwildi, O. R.; King, D. A.; Jenkins, S. J. Fischer-Tropsch synthesis of liquid fuels: learning lessons from homogeneous catalysis. Physical chemistry chemical physics : PCCP 2009, $11,11110-11112$.

(34) Liu, H.; Zhang, R.; Ling, L.; Wang, Q.; Wang, B.; Li, D. Insight into the preferred formation mechanism of long-chain hydrocarbons in Fischer-Tropsch synthesis on Hcp Co(10-11) surfaces from DFT and microkinetic modeling. Catal. Sci. Technol. 2017, 7, 3758-3776.

(35) Gunasooriya, G. T. K. K.; van Bavel, A. P.; Kuipers, H. P. C. E.; Saeys, M. Key Role of 
Surface Hydroxyl Groups in C-O Activation during Fischer-Tropsch Synthesis. ACS Catal. 2016, 6, 3660-3664.

(36) Vanbarneveld, W. Reactions of $\mathrm{CHxCl} 4 \$$ minus; $\mathrm{x}$ with hydrogen: Relation to the FischerTropsch synthesis of hydrocarbons. J. Catal. 1984, 88, 382-387.

(37) James, O. O.; Chowdhury, B.; Mesubi, M. A.; Maity, S. Reflections on the chemistry of the Fischer-Tropsch synthesis. RSC Adv. 2012, 2, 7347-7366.

(38) Brady, R. C.; Pettit, R. Reactions of diazomethane on transition-metal surfaces and their relationship to the mechanism of the Fischer-Tropsch reaction. J.Am. Chem. Soc. 1980, 102, 61816182.

(39) Corral Valero, M.; Raybaud, P. Cobalt Catalyzed Fischer-Tropsch Synthesis: Perspectives Opened by First Principles Calculations. Catal. Lett. 2012, 143, 1-17.

(40) Kobori, Y.; Yamasaki, H.; Naito, S.; Onishi, T.; Tamaru, K. Mechanistic Study of CarbonMonoxide Hydrogenation over Ruthenium Catalysts. J. Chem. Soc. Faraday Trans. 1982, 78, 1473-1490.

(41) Yamasaki, H.; Kobori, Y.; Naito, S.; Onishi, T.; Tamaru, K. Infrared Study of the Reaction of H2+Co on a Ru-Sio2 Catalyst. J. Chem. Soc. Faraday Trans. 1981, 77, 2913-2925.

(42) Brady, R. C.; Pettit, R. Mechanism of the Fischer-Tropsch reaction. The chain propagation step. J. Am. Chem. Soc. 1981, 103, 1287-1289.

(43) Markvoort, A. J.; van Santen, R. A.; Hilbers, P. A. J.; Hensen, E. J. M. Kinetics of the Fischer-Tropsch Reaction. Angewandte Chemie 2012, 124, 9149-9153.

(44) Zhuo, M. K.; Borgna, A.; Saeys, M. Effect of the CO coverage on the Fischer-Tropsch synthesis mechanism on cobalt catalysts. J. Catal. 2013, 297, 217-226.

(45) Zhuo, M. K.; Tan, K. F.; Borgna, A.; Saeys, M. Density Functional Theory Study of the CO Insertion Mechanism for Fischer-Tropsch Synthesis over Co Catalysts. J. Phys. Chem. C 2009, $113,8357-8365$.

(46) Zhao, Y. H.; Sun, K.; Ma, X.; Liu, J.; Sun, D.; Su, H. Y.; Li, W. X. Carbon chain growth by formyl insertion on rhodium and cobalt catalysts in syngas conversion. Angew. Chem. Int. Ed. 2011, 50, 5335-5338.

(47) Chen, C.; Wang, Q.; Wang, G.; Hou, B.; Jia, L.; Li, D. High coverage CO adsorption and dissociation on the $\mathrm{Co}(0001)$ and $\mathrm{Co}(100)$ surfaces from DFT and thermodynamics. J. Phys. Chem. C 2016, 120, 9132-9147.

(48) Schweicher, J.; Bundhoo, A.; Kruse, N. Hydrocarbon chain lengthening in catalytic CO hydrogenation: evidence for a CO-insertion mechanism. J. Am. Chem. Soc. 2012, 134, 1613516138.

(49) van Santen, R. A.; Markvoort, A. J. Chain Growth by CO Insertion in the Fischer-Tropsch Reaction. ChemCatChem 2013, 5, 3384-3397.

(50) Oosterbeek, H. Bridging the pressure and material gap in heterogeneous catalysis: cobalt Fischer-Tropsch catalysts from surface science to industrial application. Phys Chem Chem Phys 2007, 9, 3570-3576.

(51) Yang, N.; Medford, A. J.; Liu, X.; Studt, F.; Bligaard, T.; Bent, S. F.; Norskov, J. K. Intrinsic Selectivity and Structure Sensitivity of Rhodium Catalysts for C(2+) Oxygenate Production. J. Am. Chem. Soc. 2016, 138, 3705-3714.

(52) Filot, I. A.; van Santen, R. A.; Hensen, E. J. The Optimally Performing Fischer-Tropsch Catalyst. Angew. Chem. Int. Ed. 2014, 53, 12746-12750.

(53) Filot, I. A. W.; Broos, R. J. P.; van Rijn, J. P. M.; van Heugten, G. J. H. A.; van Santen, R. A.; Hensen, E. J. M. First-Principles-Based Microkinetics Simulations of Synthesis Gas 
Conversion on a Stepped Rhodium Surface. ACS Catal. 2015, 5, 5453-5467.

(54) van Santen, R. A.; Ghouri, M.; Hensen, E. M. Microkinetics of oxygenate formation in the Fischer-Tropsch reaction. Physical chemistry chemical physics : PCCP 2014, 16, 10041-10058.

(55) Filot, I. A. W.; Zijlstra, B.; Broos, R. J. P.; Chen, W.; Pestman, R.; Hensen, E. J. M. Kinetic aspects of chain growth in Fischer-Tropsch synthesis, Faraday Discuss. 2017, 197, 153-164.

(56) Broos, R. J. P.; Zijlstra, B.; Filot, I. A. W.; Hensen, E. J. M. Quantum-Chemical DFT Study of Direct and $\mathrm{H}$ - and C-Assisted CO Dissociation on the chi-Fe5C2 Hagg Carbide. The journal of physical chemistry. C, Nanomaterials and interfaces 2018, 122, 9929-9938.

(57) van Santen, R. A.; Markvoort, A. J.; Ghouri, M. M.; Hilbers, P. A. J.; Hensen, E. J. M. Monomer Formation Model versus Chain Growth Model of the Fischer-Tropsch Reaction. The Journal of Physical Chemistry C 2013, 117, 4488-4504.

(58) Wu, C.; Schmidt, D. J.; Wolverton, C.; Schneider, W. F. Accurate coverage-dependence incorporated into first-principles kinetic models: Catalytic NO oxidation on $\mathrm{Pt}$ (111). J Catal 2012, 286, 88-94.

(59) Marshall, S. T.; Medlin, J. W. Surface-level mechanistic studies of adsorbate-adsorbate interactions in heterogeneous catalysis by metals. Surface Science Reports 2011, 66, 173-184.

(60) Grabow, L. C.; Hvolbaek, B.; Norskov, J. K. Understanding Trends in Catalytic Activity: The Effect of Adsorbate-Adsorbate Interactions for CO Oxidation Over Transition Metals. Top. Catal. 2010, 53, 298-310.

(61) Lausche, A. C.; Medford, A. J.; Khan, T. S.; Xu, Y.; Bligaard, T.; Abild-Pedersen, F.; Norskov, J. K.; Studt, F. On the effect of coverage-dependent adsorbate-adsorbate interactions for CO methanation on transition metal surfaces. J. Catal. 2013, 307, 275-282.

(62) Campbell, C. T. Future Directions and Industrial Perspectives Micro- and macro-kinetics: Their relationship in heterogeneous catalysis. Top. Catal. 1994, 1, 353-366.

(63) Campbell, C. T. Finding the Rate-Determining Step in a Mechanism. J. Catal. 2001, 204, 520-524.

(64) Stegelmann, C.; Andreasen, A.; Campbell, C. T. Degree of rate control: how much the energies of intermediates and transition states control rates. J. Am. Chem. Soc. 2009, 131, 80778082.

(65) Campbell, C. T. The Degree of Rate Control: A Powerful Tool for Catalysis Research. ACS Catal. 2017, 7, 2770-2779.

(66) Carroll, K. J.; Huba, Z. J.; Spurgeon, S. R.; Qian, M. C.; Khanna, S. N.; Hudgins, D. M.; Taheri, M. L.; Carpenter, E. E. Magnetic properties of $\mathrm{Co} 2 \mathrm{C}$ and $\mathrm{Co} 3 \mathrm{C}$ nanoparticles and their assemblies. Appl Phys Lett 2012, 101, 012409.

(67) Perdew, J. P.; Burke, K.; Ernzerhof, M. Generalized Gradient Approximation Made Simple. Phys. Rev. Lett. 1996, 77, 3865-3868.

(68) Kresse, G.; Furthmüller, J. Non-ASF product distributions due to secondary reactions during Fischer-Tropsch synthesis. Comput. Mater. Sci. 1996, 6, 15-50.

(69) Kresse, G.; Hafner, J. Ab initio molecular-dynamics simulation of the liquid-metalamorphous-semiconductor transition in germanium. Phys. Rev. B 1994, 49, 14251-14269.

(70) Kresse, G.; Joubert, D. From ultrasoft pseudopotentials to the projector augmented-wave method. Phys. Rev. B 1999, 59, 1758-1775.

(71) Blöchl, P. E.; Jepsen, O.; Andersen, O. K. Improved tetrahedron method for Brillouin-zone integrations. Phys. Rev. B 1994, 49, 16223-16233.

(72) Cheng, J.; Song, T.; Hu, P.; Lok, C. M.; Ellis, P.; French, S. A density functional theory study of the $\alpha$-olefin selectivity in Fischer-Tropsch synthesis. J. Catal. 2008, 255, 20-28. 
(73) Grimme, S.; Ehrlich, S.; Goerigk, L. Effect of the damping function in dispersion corrected density functional theory. J. Comput. Chem. 2011, 32, 1456-1465.

(74) Grimme, S.; Antony, J.; Ehrlich, S.; Krieg, H. consistent and accurate ab initio parametrization of density functional dispersion correction (DFT-D) for the 94 elements H-Pu. $J$. Chem. Phys. 2010, 132, 154104.

(75) Alavi, A.; Hu, P.; Deutsch, T.; Silvestrelli, P. L.; Hutter, J. CO Oxidation on Pt(111): AnAb InitioDensity Functional Theory Study. Phys. Rev. Lett. 1998, 80, 3650-3653.

(76) Liu, Z.-P.; Hu, P. General Rules for Predicting Where a Catalytic Reaction Should Occur on Metal Surfaces: A Density Functional Theory Study of C-H and C-O Bond Breaking/Making on Flat, Stepped, and Kinked Metal Surfaces. J. Am. Chem. Soc. 2003, 125, 1958-1967.

(77) Michaelides, A.; Liu, Z. P.; Zhang, C. J.; Alavi, A.; King, D. A.; Hu, P. Identification of General Linear Relationships between Activation Energies and Enthalpy Changes for Dissociation Reactions at Surfaces. J. Am. Chem. Soc. 2003, 125, 3704-3705.

(78) GaussView, V., Dennington, Roy; Keith, Todd; Millam, John. Semichem Inc., Shawnee Mission, KS, 2009.

(79) Lee, C.; Yang, W.; Parr, R. G. Development of the Colle-Salvetti correlation-energy formula into a functional of the electron density. Phys. Rev. B 1988, 37, 785-789.

(80) Becke, A. D. Density-functional thermochemistry. III. The role of exact exchange. J. Chem. Phys. 1993, 98, 5648-5652.

(81) Cheng, J.; Gong, X. Q.; Hu, P.; Lok, C. M.; Ellis, P.; French, S. A quantitative determination of reaction mechanisms from density functional theory calculations: Fischer-Tropsch synthesis on flat and stepped cobalt surfaces. J. Catal. 2008, 254, 285-295.

(82) Cheng, J.; Hu, P.; Ellis, P.; French, S.; Kelly, G.; Lok, C. M. A DFT study of the chain growth probability in Fischer-Tropsch synthesis. J. Catal. 2008, 257, 221-228.

(83) Cheng, J.; Hu, P.; Ellis, P.; French, S.; Kelly, G.; Lok, C. M. Chain growth mechanism in Fischer-Tropsch synthesis: A DFT study of C-C coupling over Ru, Fe, Rh, and Re surfaces. J. Phys. Chem. C 2008, 112, 6082-6086.

(84) Cheng, J.; Hu, P.; Ellis, P.; French, S.; Kelly, G.; Lok, C. M. A First-Principles Study of Oxygenates on Co Surfaces in Fischer-Tropsch Synthesis. J. Phys. Chem. C 2008, 112, 9464-9473.

(85) Cheng, J.; Hu, P.; Ellis, P.; French, S.; Kelly, G.; Lok, C. M. An Energy Descriptor To Quantify Methane Selectivity in Fischer-Tropsch Synthesis: A Density Functional Theory Study.

J. Phys. Chem. C 2009, 113, 8858-8863.

(86) Cheng, J.; Hu, P.; Ellis, P.; French, S.; Kelly, G.; Lok, C. M. Some Understanding of Fischer-Tropsch Synthesis from Density Functional Theory Calculations. Top. Catal. 2010, 53, 326-337.

(87) Cheng, J.; Hu, P.; Ellis, P.; French, S.; Kelly, G.; Lok, C. M. Density Functional Theory Study of Iron and Cobalt Carbides for Fischer-Tropsch Synthesis. J. Phys. Chem. C 2010, 114, 1085-1093.

(88) Mitchell, W. J.; Wang, Y.; Xie, J.; Weinberg, W. H. Hydrogenation of carbon monoxide at $100 \mathrm{~K}$ on the ruthenium(001) surface: spectroscopic identification of formyl intermediates. J. Am. Chem. Soc. 1993, 115, 4381-4382.

(89) Mitchell, W. J.; Xie, J.; Jachimowski, T. A.; Weinberg, W. H. Carbon Monoxide Hydrogenation on the $\mathrm{Ru}(001)$ Surface at Low Temperature Using Gas-Phase Atomic Hydrogen: Spectroscopic Evidence for the Carbonyl Insertion Mechanism on a Transition Metal Surface. $J$. Am. Chem. Soc. 1995, 117, 2606-2617.

(90) Morgan, G. A., Jr.; Sorescu, D. C.; Zubkov, T.; Yates, J. T. Jr. The Formation and Stability 
of Adsorbed Formyl as a Possible Intermediate in Fischer-Tropsch Chemistry on Ruthenium. $J$ Phys Chem B 2004, 108, 3614-3624.

(91) Beitel, G. A.; de Groot, C. P. M.; Oosterbeek, H.; Wilson, J. H. A Combinedin-SituPMRAIRS and Kinetic Study of Single-Crystal Cobalt Catalysts under Synthesis Gas at Pressures up to 300 mbar. J. Phys. Chem. B 1997, 101, 4035-4043.

(92) Beitel, G. A.; Laskov, A.; Oosterbeek, H.; Kuipers, E. W. Polarization Modulation Infrared Reflection Absorption Spectroscopy of CO Adsorption on $\mathrm{Co}(0001)$ under a High-Pressure Regime. J. Phys. Chem. 1996, 100, 12494-12502.

(93) Bedolla, P. O.; Feldbauer, G.; Wolloch, M.; Eder, S. J.; Dorr, N.; Mohn, P.; Redinger, J.; Vernes, A. Effects of van der Waals Interactions in the Adsorption of Isooctane and Ethanol on Fe(100) Surfaces. J. Phys. Chem. C 2014, 118, 17608-17615.

(94) Klimes, J.; Bowler, D. R.; Michaelides, A. Chemical accuracy for the van der Waals density functional. Journal of physics. Condensed matter : an Institute of Physics journal 2010, 22, 022201. (95) Klimeš, J.; Bowler, D. R.; Michaelides, A. Van der Waals density functionals applied to solids. Phys. Rev. B 2011, 83, 195131.

(96) Tereshchuk, P.; Da Silva, J. L. F. Ethanol and Water Adsorption on Close-Packed 3d, 4d, and 5d Transition-Metal Surfaces: A Density Functional Theory Investigation with van der Waals Correction. J. Phys. Chem. C 2012, 116, 24695-24705.

(97) Gong, X. Q.; Raval, R.; Hu, P. CHx hydrogenation on Co(0001): a density functional theory study. J. Chem. Phys. 2005, 122, 024711.

(98) Ciobı ^ă a. I. M.; Frechard, F.; van Santen, R. A.; Kleyn, A. W.; Hafner, J. A theoretical study of CHx chemisorption on the Ru(0001) surface. Chem. Phys. Lett. 1999, 311, 185-192.

(99) Qi, Y.; Yang, J.; Duan, X.; Zhu, Y.-A.; Chen, D.; Holmen, A. Discrimination of the mechanism of CH4 formation in Fischer-Tropsch synthesis on Co catalysts: a combined approach of DFT, kinetic isotope effects and kinetic analysis. Catal. Sci. Technol. 2014, 4, 3534-3543.

(100) Ojeda, M.; Nabar, R.; Nilekar, A. U.; Ishikawa, A.; Mavrikakis, M.; Iglesia, E. CO activation pathways and the mechanism of Fischer-Tropsch synthesis. J. Catal. 2010, 272, 287297.

(101) Yang, J.; Qi, Y. Y.; Zhu, J.; Zhu, Y. A.; Chen, D.; Holmen, A. Reaction mechanism of CO activation and methane formation on Co Fischer-Tropsch catalyst: A combined DFT, transient, and steady-state kinetic modeling. J. Catal. 2013, 308, 37-49.

(102) Pendyala, V. R. R.; Shafer, W. D.; Jacobs, G.; Davis, B. H. Fischer-Tropsch Synthesis: Effect of Reaction Temperature for Aqueous-Phase Synthesis Over a Platinum Promoted Co/Alumina Catalyst. Catal. Lett. 2014, 144, 1088-1095.

(103) Ishida, T.; Yanagihara, T.; Liu, X.; Ohashi, H.; Hamasaki, A.; Honma, T.; Oji, H.; Yokoyama, T.; Tokunaga, M. Synthesis of higher alcohols by Fischer-Tropsch synthesis over alkali metal-modified cobalt catalysts. Applied Catalysis A: General 2013, 458, 145-154.

(104) Khodakov, A. Y.; Chu, W.; Fongarland, P. Advances in the development of novel cobalt Fischer-Tropsch catalysts for synthesis of long-chain hydrocarbons and clean fuels. Chem. Rev. 2007, 107, 1692-1744.

(105) Iglesia, E. Transport-enhanced \$alpha;-olefin readsorption pathways in Ru-catalyzed hydrocarbon synthesis. J. Catal. 1991, 129, 238-256.

(106) Iglesia, E.; Reyes, S. C.; Madon, R. J.; Soled, S. L. Selectivity Control and Catalyst Design in the Fischer-Tropsch Synthesis - Sites, Pellets, and Reactors. Adv. Catal. 1993, 39, 221-302.

(107) Kuipers, E. Chain Length Dependence of $\alpha$-Olefin Readsorption in Fischer-Tropsch Synthesis. J. Catal. 1995, 152, 137-146. 
(108) Kuipers, E. W.; Scheper, C.; Wilson, J. H.; Vinkenburg, I. H.; Oosterbeek, H. Non-ASF product distributions due to secondary reactions during Fischer-Tropsch synthesis. J. Catal. 1996, $158,288-300$.

(109) Madon, R. The Importance of Olefin Readsorption and H2/CO Reactant Ratio for Hydrocarbon Chain Growth on Ruthenium Catalysts. J. Catal. 1993, 139, 576-590.

(110) Schulz, H.; Beck, K.; Erich, E. Mechanism of the Fischer Tropsch Process. Stud. Surf. Sci. Catal. 1988, 36, 457-471.

(111) Shi, B. C.; Davis, B. H. Fischer-Tropsch synthesis: The paraffin to olefin ratio as a function of carbon number. Catal. Today 2005, 106, 129-131. 


\section{Graphical TOC Entry}

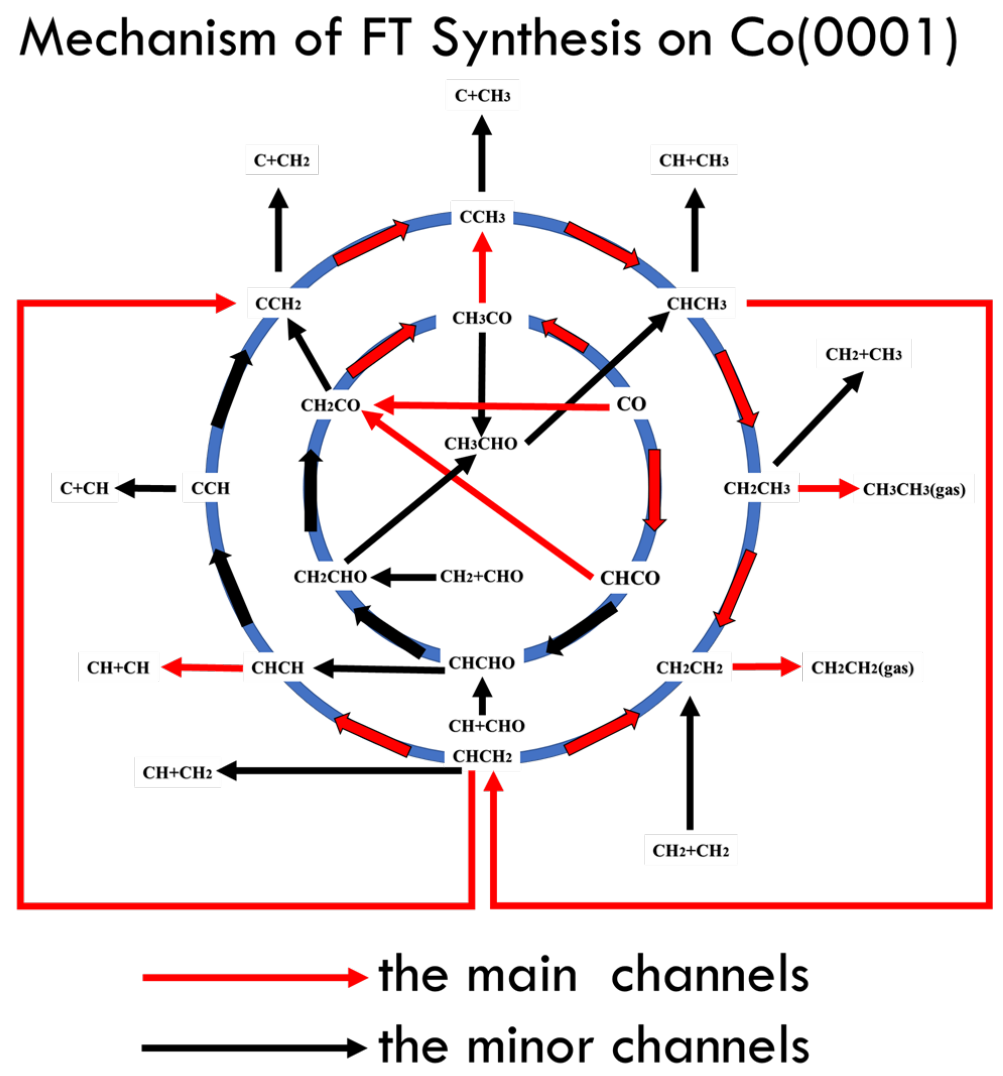




\title{
Supporting Information
}

\section{Quantitative Determination of C-C Coupling Mechanisms and Detailed Analyses on the Activity and Selectivity for Fischer- Tropsch Synthesis on Co(0001): Microkinetic Modelling with Coverage Effects}

\author{
Zihao Yao, Chenxi Guo, Yu Mao, and P. Hu* \\ *Corresponding author:P.Hu, p.hu@qub.ac.uk
}

School of Chemistry and Chemical Engineering, The Queen's University of Belfast, Belfast, BT9 5AG, U.K. 


\subsection{Adsorption Sites}

Table S1. Generalized formation energies formulas and the corresponding energy of intermediates (unit is in eV). Parameterization of energy can avoid mistake and workload using generalized formation energy. This concept from Catmap ${ }^{1}$ can be applied in our FT system. In our system $\mathrm{R}_{\mathrm{H}}=0.5\left(\mathrm{U}_{\mathrm{H}_{2}}\right), \mathrm{R}_{\mathrm{C}}=\mathrm{U}_{\mathrm{CH}_{4}}-4 \mathrm{R}_{\mathrm{H}}, \mathrm{R}_{\mathrm{O}}=\mathrm{U}_{\mathrm{H}_{2} \mathrm{O}}-2 \mathrm{R}_{\mathrm{H}}$. Herein $\mathrm{E}$ is generalized formation energy, $\mathrm{U}$ is the free energy calculated in the DFT, $\mathrm{R}$ is the reference atomic species. The formula to obtain the formation energies are also given. The geometries are the most stable sites from our calculations.

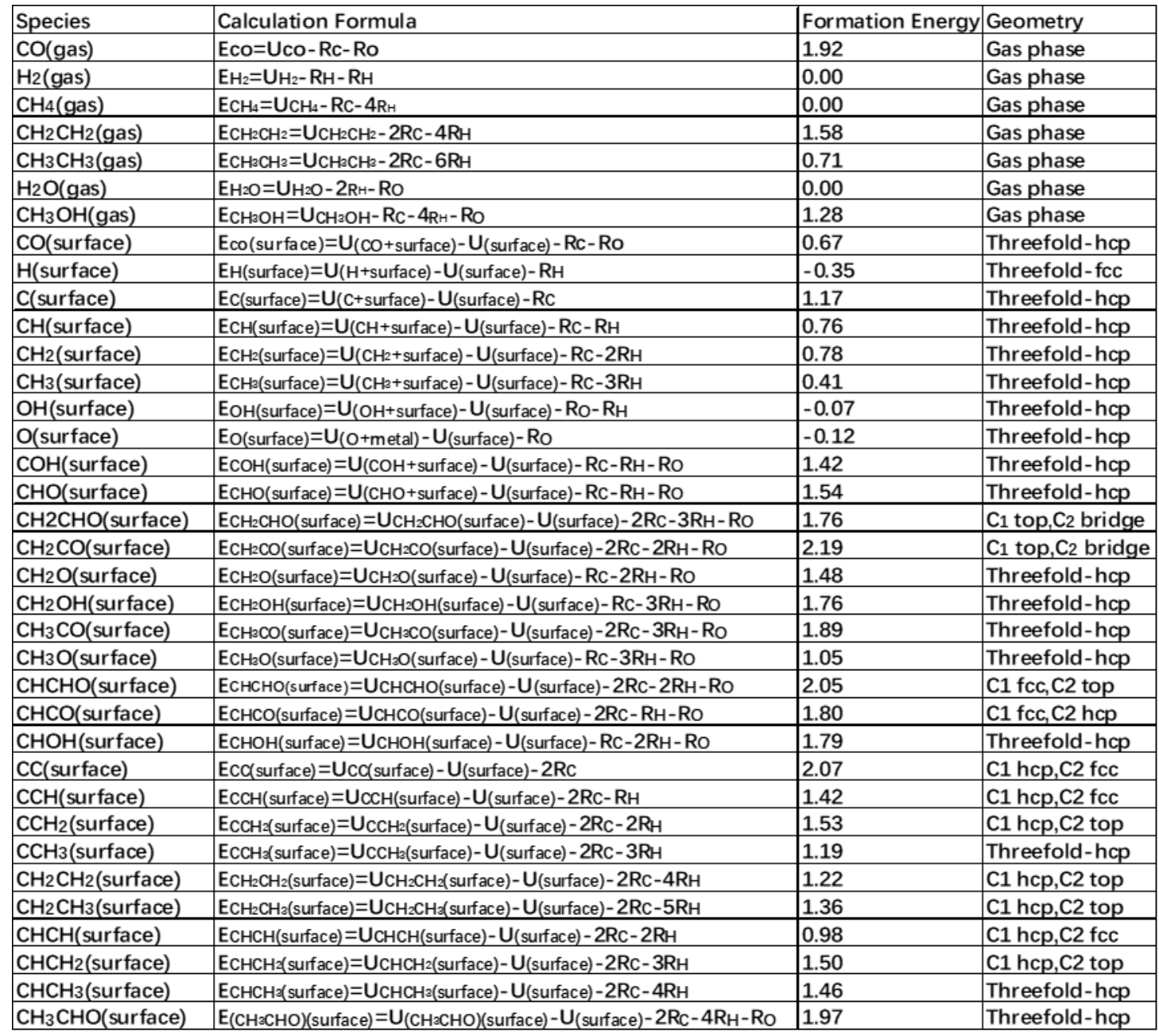


(a)

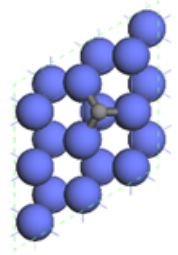

(f)

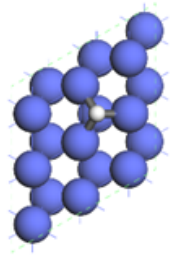

(k)

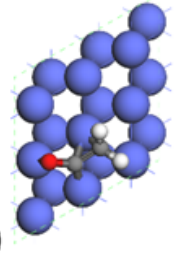

(p)

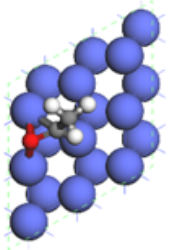

(u)

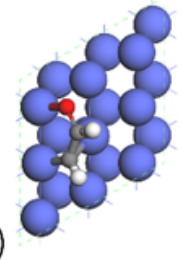

(b)

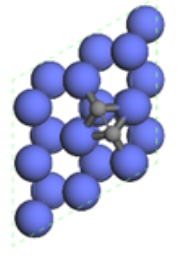

(g)

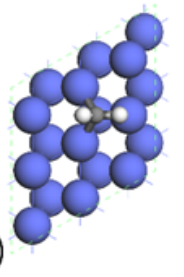

(I)

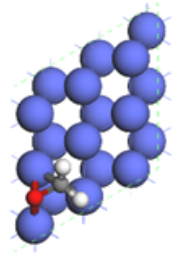

(q)

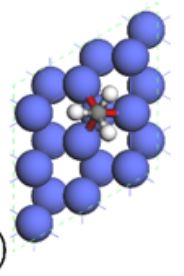

(v)

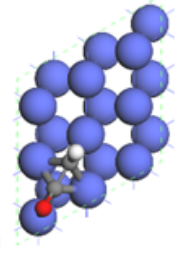

(c)

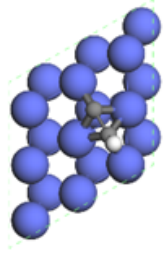

(h)

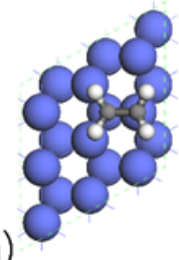

(m)

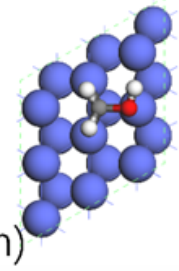

(r)

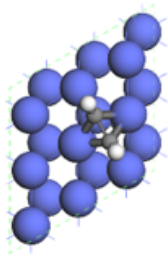

(w)

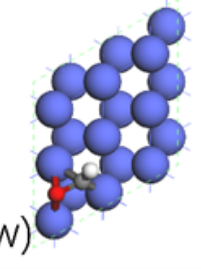

(d)

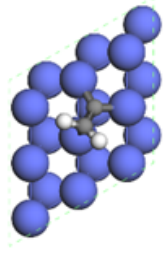

(i)

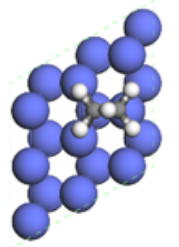

(n)

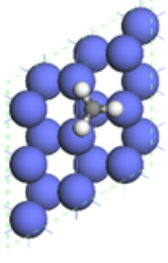

(s)

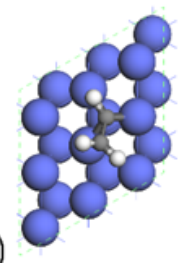

(x)

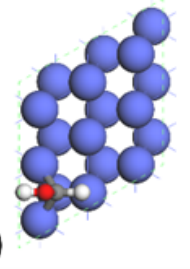

(e)

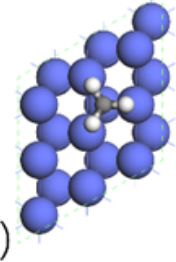

(j)

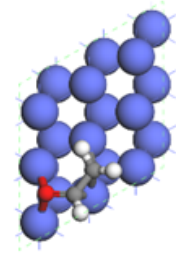

(o)

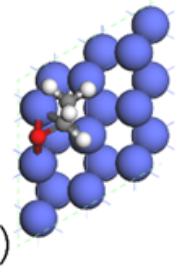

(t)

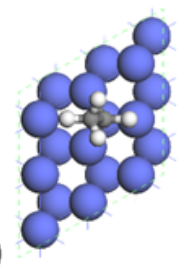

(y)

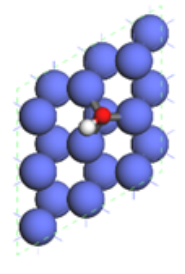

(z)

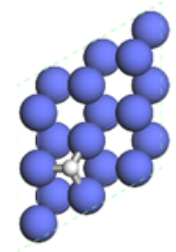

(aa)
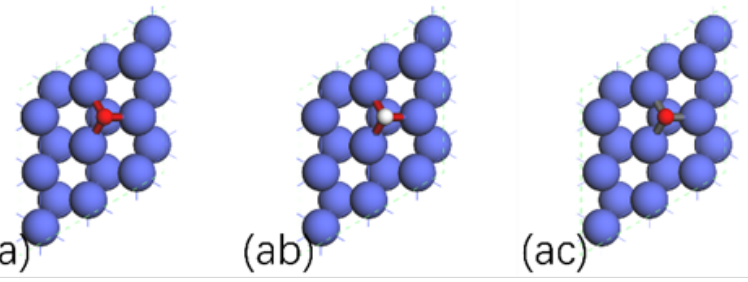

Figure S1. Top views of all the optimized geometries of intermediates on $\mathrm{Co}(0001)$. (a) C; (b) $\mathrm{CC}$; (c) $\mathrm{CCH}$; (d) $\mathrm{CCH}_{2}$; (e) $\mathrm{CCH}_{3}$; (f) $\mathrm{CH}$; (g) $\mathrm{CH}_{2}$; (h) $\mathrm{CH}_{2} \mathrm{CH}_{2}$; (i) $\mathrm{CH}_{3} \mathrm{CH}_{2}$; (j) $\mathrm{CH}_{2} \mathrm{CHO}$; (k) $\mathrm{CH}_{2} \mathrm{CO}$; (l) $\mathrm{CH}_{2} \mathrm{O}$; (m) $\mathrm{CH}_{2} \mathrm{OH}$; (n) $\mathrm{CH}_{3}$; (o) $\mathrm{CH}_{3} \mathrm{CHO}$; (p) $\mathrm{CH}_{3} \mathrm{CO}$; (q) $\mathrm{CH}_{3} \mathrm{O}$; (r) $\mathrm{CHCH}$; (s) $\mathrm{CHCH}_{2}$; (t) $\mathrm{CHCH}_{3}$; (u) $\mathrm{CHCHO}$; (v) $\mathrm{CHCO}$; (w) $\mathrm{CHO}$; (x) $\mathrm{CHOH}$; (y) OH; (z) H; (aa) O; (ab) $\mathrm{OH}$; and (ac) $\mathrm{CO}$.

\subsection{Direct CO dissociation and H-assisted CO Dissociation}


The direct $\mathrm{CO}$ dissociation reaction was calculated on $\mathrm{Co}(0001){ }^{2}$ The barrier of direct $\mathrm{CO}$ dissociation is as high as $2.12 \mathrm{eV}$ (Table S2). Van Santen and his co-workers used DFT to investigate $\mathrm{CO}$ dissociation on $\mathrm{Ru}(0001)$ and their results showed that hydrogen assisted dissociation is easier than direct $\mathrm{CO}$ dissociation..$^{3-4}$ Ojeda and co-workers ${ }^{5}$ studied both direct $\mathrm{CO}$ dissociation and $\mathrm{H}$-assisted $\mathrm{CO}$ dissociation on the flat $\mathrm{Co}(0001)$ surface with $0.5 \mathrm{ML} \mathrm{CO}$; their results indicated that $\mathrm{H}$-assisted $\mathrm{CO}$ dissociation is dominated on the surface. Recently, $\mathrm{Li}$ and coworkers ${ }^{6}$ studied $\mathrm{CH}_{\mathrm{x}}$ formation on a $\mathrm{Co}(10 \overline{1} 1)$ surface and their results shown that $\mathrm{CO}$ hydrogenation to $\mathrm{CHO}$ is the most possible pathway to form monomers. Their findings were very similar to our calculated results which are listed in Table S2. The transition state structures are displayed in Figure S2, and corresponding energy data for the transition states are shown in Table $\mathrm{S} 2$. The barrier of $\mathrm{CHO}$ dissociation is much lower than direct $\mathrm{CO}$ dissociation. The calculated $\mathrm{COH}$ and $\mathrm{CHO}$ dissociation energies are $1.56 \mathrm{eV}$ and $0.36 \mathrm{eV}$, respectively. Our energy profiles are shown in Figure S3 and the effective barriers are $2.12 \mathrm{eV}, 2.32 \mathrm{eV}$, and $1.77 \mathrm{eV}$ for direct $\mathrm{CO}$ dissociation, $\mathrm{COH}$ dissociation and $\mathrm{CHO}$ dissociation, respectively. In other words, $\mathrm{H}$-assisted $\mathrm{CHO}$ dissociation is the most possible pathway to form the monomer from the non-coverage dependent kinetic simulations on $\mathrm{Co}(0001)$.

Table S2. The barriers and reaction energies of elementary reactions of direct $\mathrm{CO}$ dissociation and $\mathrm{H}$-assisted $\mathrm{CO}$ dissociation.

\begin{tabular}{|c|c|c|}
\hline Elementary reaction & $\begin{array}{l}\text { Forward reaction } \\
\text { barrier }(\mathrm{eV})\end{array}$ & Reaction energy $(\mathrm{eV})$ \\
\hline $\mathrm{CO}^{*}+* \rightleftarrows \mathrm{C}^{*}+\mathrm{O}^{*}$ & 2.12 & 0.38 \\
\hline $\mathrm{CO}^{*}+\mathrm{H}^{*} \rightleftarrows \mathrm{COH}^{*}+*$ & 1.76 & 1.09 \\
\hline $\mathrm{CO}^{*}+\mathrm{H}^{*} \rightleftarrows \mathrm{CHO}^{*}+*$ & 1.34 & 1.22 \\
\hline $\mathrm{COH}^{*}+* \rightleftarrows \mathrm{C}^{*}+\mathrm{OH}^{*}$ & 1.65 & -0.31 \\
\hline $\mathrm{CHO}^{*}+* \rightleftarrows \mathrm{CH}^{*}+\mathrm{O}^{*}$ & 0.56 & -0.91 \\
\hline
\end{tabular}




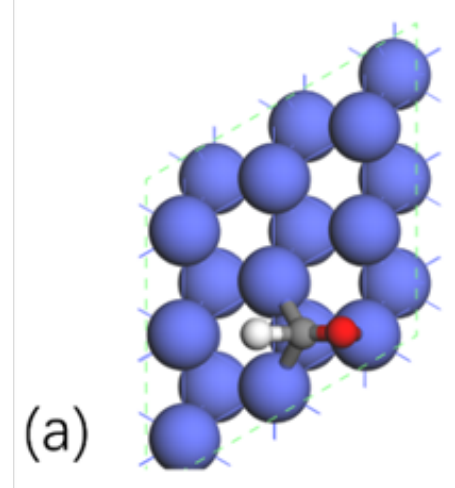

(b)
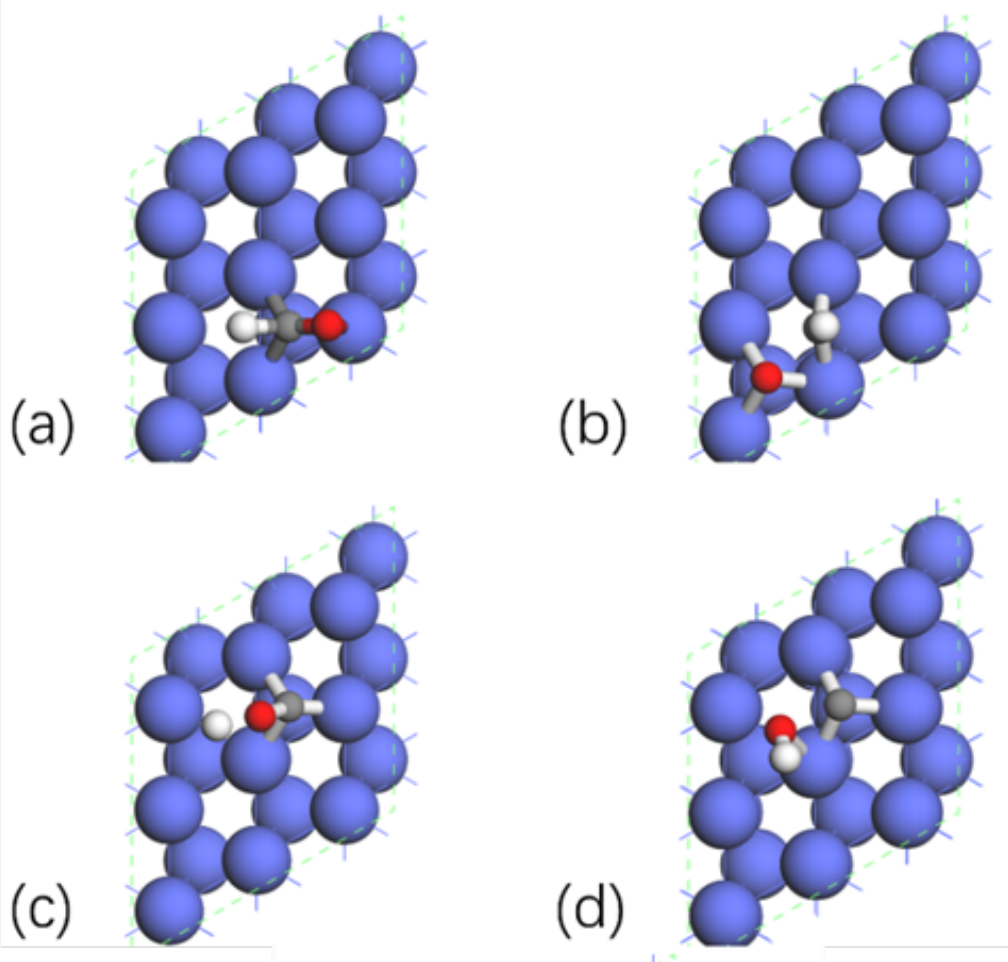

(d)

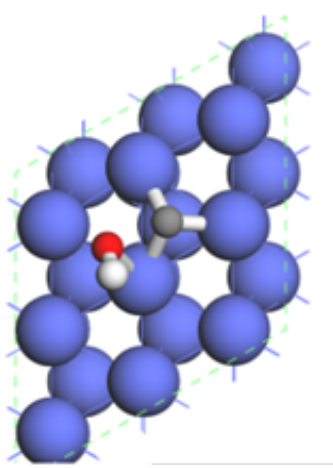

(e)

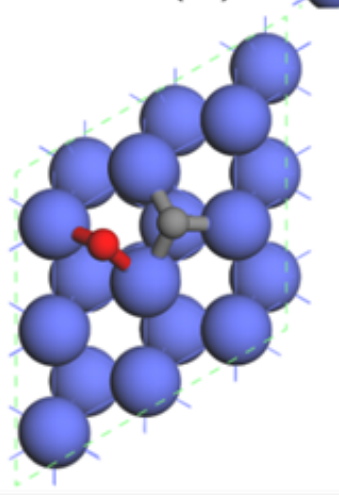

Figure S2. Top views of calculated transition state geometries of direct $\mathrm{CO}$ dissociation and $\mathrm{H}$ assisted $\mathrm{CO}$ dissociation reactions on $\mathrm{Co}(0001)$. (a) $\mathrm{TS}_{\mathrm{CO}+\mathrm{H}(\mathrm{CHO})}$; (b) $\mathrm{TS}_{\mathrm{CHO}(\mathrm{CH}+\mathrm{O})}$; (c) $\mathrm{TS}_{\mathrm{CO}+\mathrm{H}(\mathrm{COH})}$; (d) $\mathrm{TS}_{\mathrm{COH}(\mathrm{C}+\mathrm{OH})}$; and (e) $\mathrm{TS}_{\mathrm{CO}(\mathrm{C}+\mathrm{O})}$. 
Table S3. Distances of transition states of direct $\mathrm{CO}$ dissociation and $\mathrm{H}$-assisted $\mathrm{CO}$ dissociation reactions.

\begin{tabular}{lll}
\hline & Transition State & Distance $(\AA)$ \\
\hline (a) & $\mathrm{TS}_{\mathrm{CO}+\mathrm{H}(\mathrm{CHO})}$ & 1.17 \\
(b) & $\mathrm{TS}_{\mathrm{CHO}(\mathrm{CH}+\mathrm{O})}$ & 1.79 \\
(c) & $\mathrm{TS}_{\mathrm{CO}+\mathrm{H}(\mathrm{COH})}$ & 1.3 \\
(d) & $\mathrm{TS}_{\mathrm{COH}(\mathrm{C}+\mathrm{OH})}$ & 1.8 \\
(e) & $\mathrm{TS}_{\mathrm{CO}(\mathrm{C}+\mathrm{O})}$ & 1.85 \\
\hline
\end{tabular}

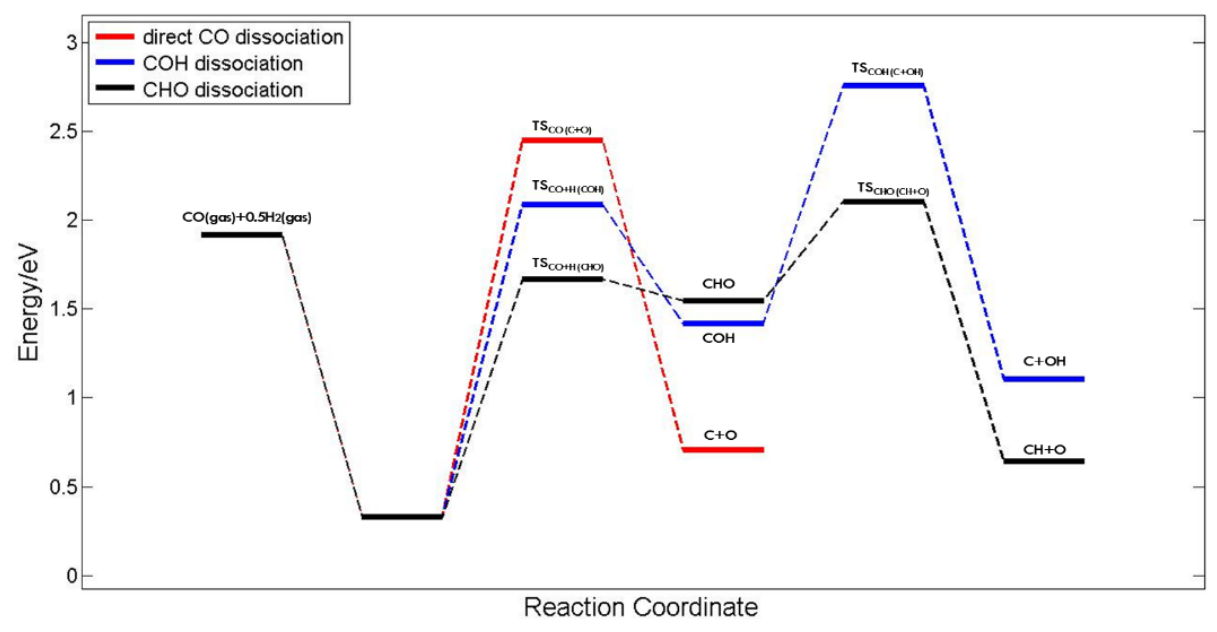

Figure S3. Energy profiles of direct $\mathrm{CO}$ dissociation and $\mathrm{H}$-assisted $\mathrm{CO}$ dissociation reactions on $\mathrm{Co}(0001)$. The path in red is $\mathrm{CO}(\mathrm{gas})+0.5 \mathrm{H}_{2}(\mathrm{gas}) \rightarrow \mathrm{CO}(\mathrm{ad})+\mathrm{H}(\mathrm{ad}) \rightarrow \mathrm{TS}_{\mathrm{CO}(\mathrm{C}+\mathrm{O})}(\mathrm{ad})+\mathrm{H}(\mathrm{ad}) \rightarrow$ $\mathrm{C}(\mathrm{ad})+\mathrm{O}(\mathrm{ad})+\mathrm{H}(\mathrm{ad})$. The path in blue is $\mathrm{CO}(\mathrm{gas})+0.5 \mathrm{H}_{2}(\mathrm{gas}) \rightarrow \mathrm{CO}(\mathrm{ad})+\mathrm{H}(\mathrm{ad}) \rightarrow \mathrm{TS}_{\mathrm{CO}+\mathrm{H}}$ (СоH) $(\mathrm{ad}) \rightarrow \mathrm{COH}(\mathrm{ad}) \rightarrow \mathrm{C}(\mathrm{ad})+\mathrm{OH}(\mathrm{ad})$. The path in black is $\mathrm{CO}(\mathrm{gas})+0.5 \mathrm{H}_{2}(\mathrm{gas}) \rightarrow$ $\mathrm{CO}(\mathrm{ad})+\mathrm{H}(\mathrm{ad}) \rightarrow \mathrm{TS}_{\mathrm{CO}+\mathrm{H}(\mathrm{CHO})}(\mathrm{ad}) \rightarrow \mathrm{CHO}(\mathrm{ad}) \rightarrow \mathrm{CH}(\mathrm{ad})+\mathrm{O}(\mathrm{ad})$.

\subsection{Water Formation}

Gong et al. ${ }^{2}$ investigated the $\mathrm{O}$ removal on both the flat and stepped cobalt surfaces. However, proton migration between two hydroxyl groups was not included in the calculation which was 
highlighted by van Santen and his co-workers. ${ }^{7-8}$ Michaelides and $\mathrm{Hu}^{9}$ investigated water formation on $\mathrm{Pt}(111)$ and found that the barrier of $\mathrm{OH}^{*}+\mathrm{OH}^{*} \rightleftarrows \mathrm{H}_{2} \mathrm{O}+\mathrm{O}^{*}+*$ was only $0.13 \mathrm{eV}$. The removal of oxygen is very important for the FT reaction to form long chain hydrocarbons. Two important pathways for water formation are summarized as follows: (i) $\mathrm{O}^{*}+\mathrm{H}^{*} \rightleftarrows \mathrm{OH}^{*}+* \mathrm{OH}^{*}+\mathrm{H}^{*} \rightleftarrows$ $\mathrm{H}_{2} \mathrm{O}++^{*}$; (ii) $\mathrm{OH}^{*}+\mathrm{OH}^{*} \rightleftarrows \mathrm{H}_{2} \mathrm{O}+\mathrm{O}^{*}+*$. Proton migration between two hydroxyl groups results in a lower barrier of $0.67 \mathrm{eV}$ which is listed in Table $\mathrm{S} 4$, and the corresponding structures and distances of transition states are shown in Figure S4 and Table S4. Our energy profiles are illustrated in Figure S5, and the effective barrier of pathway (ii) is lower than pathway (i) by 0.18 $\mathrm{eV}$.

Table S4. The barriers and reaction energies of elementary reactions of water formation.

\begin{tabular}{lll}
\hline Elementary reaction & $\begin{array}{l}\text { Forward reaction } \\
\text { barrier }(\mathrm{eV})\end{array}$ & Reaction energy $(\mathrm{eV})$ \\
\hline $\mathrm{O}^{*}+\mathrm{H}^{*} \rightleftarrows \mathrm{OH}^{*}+*$ & 1.30 & 0.40 \\
$\mathrm{OH}^{*}+\mathrm{H}^{*} \rightleftarrows \mathrm{H}_{2} \mathrm{O}+*+^{*}$ & 1.48 & 0.41 \\
$\mathrm{OH}^{*}+\mathrm{OH}^{*} \rightleftarrows \mathrm{H}_{2} \mathrm{O}+\mathrm{O}^{*}+*$ & 0.67 & 0.01 \\
\hline
\end{tabular}

(a)

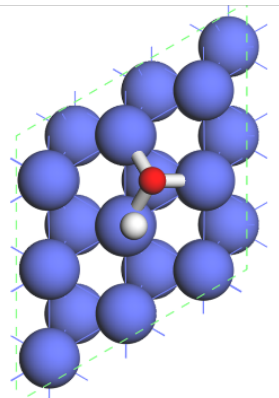

(b)

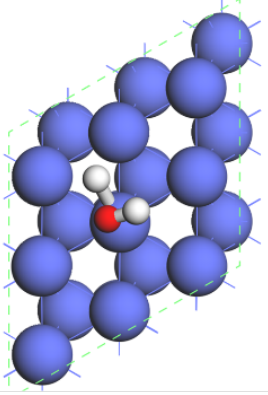

(c)

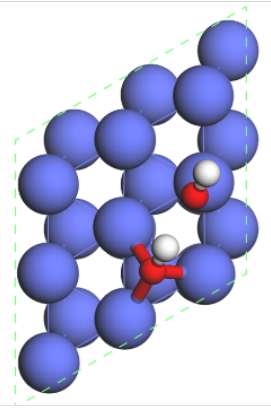

Figure S4. Top views of calculated transition state geometries of water formation on $\mathrm{Co}(0001)$. (a) $\mathrm{TS}_{\mathrm{O}+\mathrm{H}(\mathrm{OH})}$; (b) $\mathrm{TS}_{\mathrm{H}+\mathrm{OH}(\mathrm{H} 2 \mathrm{O})}$; and (c) $\mathrm{TS}_{\mathrm{OH}+\mathrm{OH}(\mathrm{H} 2 \mathrm{O}+\mathrm{O})}$. 
Table S5. Distances at the transition states of water formation.

\begin{tabular}{lll}
\hline & Transition State & Distance $(\AA)$ \\
\hline (a) & $\mathrm{TS}_{\mathrm{O}+\mathrm{H}(\mathrm{OH})}$ & 1.45 \\
(b) & $\mathrm{TS}_{\mathrm{H}+\mathrm{OH}(\mathrm{H} 2 \mathrm{O})}$ & 1.49 \\
(c) & $\mathrm{TS}_{\mathrm{OH}+\mathrm{OH}(\mathrm{H} 2 \mathrm{O}+\mathrm{O})}$ & 1.73 \\
\hline
\end{tabular}

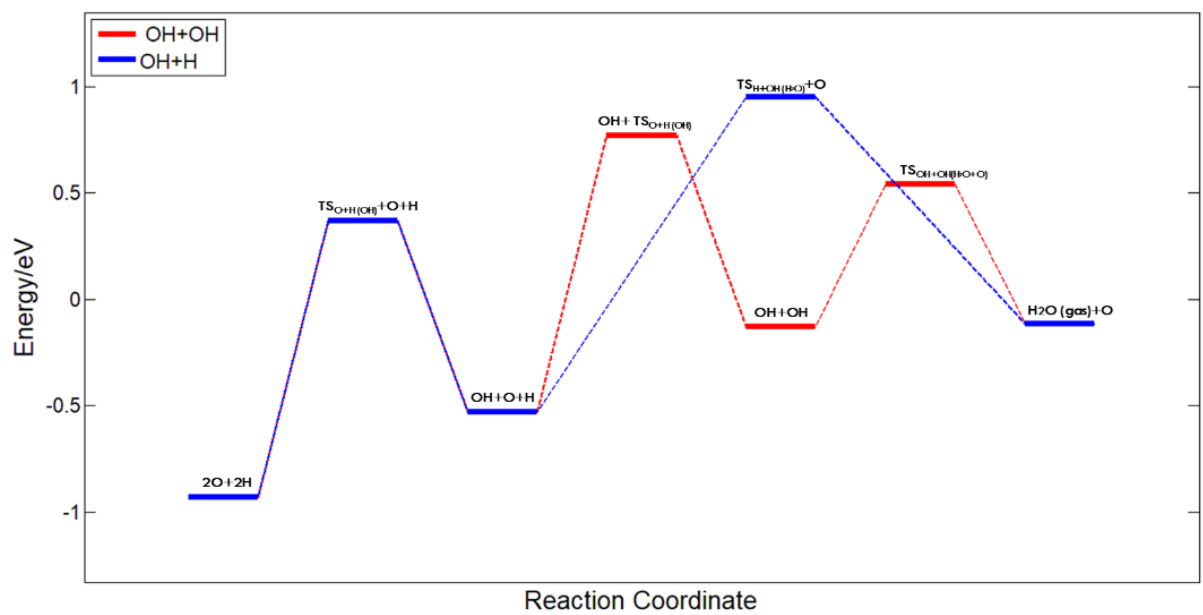

Figure S5. Energy profiles of water formation on $\mathrm{Co}(0001)$. The path in red is $2 \mathrm{O}(\mathrm{ad})+2 \mathrm{H}(\mathrm{ad}) \rightarrow$ $\mathrm{TS}_{\mathrm{O}+\mathrm{H}(\mathrm{OH})}(\mathrm{ad})+\mathrm{O}(\mathrm{ad})+\mathrm{H}(\mathrm{ad}) \rightarrow \mathrm{OH}(\mathrm{ad})+\mathrm{O}(\mathrm{ad})+\mathrm{H}(\mathrm{ad}) \rightarrow \mathrm{OH}(\mathrm{ad})$

$+\mathrm{TS}_{\mathrm{O}+\mathrm{H}(\mathrm{OH})}(\mathrm{ad}) \rightarrow \mathrm{OH}(\mathrm{ad})+\mathrm{OH}(\mathrm{ad}) \rightarrow \mathrm{TS}_{\mathrm{OH}+\mathrm{OH}(\mathrm{H} 2 \mathrm{O}+\mathrm{O})}(\mathrm{ad}) \rightarrow \mathrm{H}_{2} \mathrm{O}(\mathrm{gas})+\mathrm{O}(\mathrm{ad})$. The path in blue is $2 \mathrm{O}(\mathrm{ad})+2 \mathrm{H}(\mathrm{ad}) \rightarrow \mathrm{TS}_{\mathrm{O}+\mathrm{H}(\mathrm{OH})}(\mathrm{ad})+\mathrm{O}(\mathrm{ad})+\mathrm{H}(\mathrm{ad}) \rightarrow \mathrm{OH}(\mathrm{ad})+\mathrm{O}(\mathrm{ad})+$

$\mathrm{H}(\mathrm{ad}) \rightarrow \mathrm{TS}_{\mathrm{H}+\mathrm{OH}(\mathrm{H} 2 \mathrm{O})}(\mathrm{ad})+\mathrm{O}(\mathrm{ad}) \rightarrow \mathrm{H}_{2} \mathrm{O}(\mathrm{gas})+\mathrm{O}(\mathrm{ad})$.

\section{4 $\mathrm{C}_{1}$ Hydrogenation to Methane}

The calculated forward reaction barriers and reaction energies for $\mathrm{C}_{1}$ hydrogenation to methane in this work are listed in Table S6, and the results are very similar to a previous finding using SIESTA code. ${ }^{10}$ Our results are consistent with previous findings that the last hydrogenation step is the highest step and also in agreement with experimental work. ${ }^{11}$ The first hydrogenation of $\mathrm{C}$ to $\mathrm{CH}$ is little higher than those from $\mathrm{CH}$ to $\mathrm{CH}_{2}$ and from $\mathrm{CH}_{2}$ to $\mathrm{CH}_{3}$. The transition state structures are displayed in Figure S6 and the distances of the transition states are listed in Table S7. The energy profile in Figure S7 is consistent with the relative stabilities of adsorbates on the metal surface in Figure 5, and their relative stabilities are in the following order: $\mathrm{CH}>\mathrm{C}>\mathrm{CH}_{3}>\mathrm{CH}_{2}$. 
Table S6. The forward reaction barriers and reaction energies of elementary steps of $\mathrm{C}_{1}$ hydrogenation to methane.

\begin{tabular}{lll}
\hline Elementary reaction & Forward barrier $(\mathrm{eV})$ & Reaction energy $(\mathrm{eV})$ \\
\hline $\mathrm{H}^{*}+\mathrm{C}^{*} \rightleftarrows \mathrm{CH}^{*}+*$ & 0.71 & -0.07 \\
$\mathrm{H}^{*}+\mathrm{CH}^{*} \rightleftarrows \mathrm{CH}_{2}+^{*}$ & 0.53 & 0.37 \\
$\mathrm{H}^{*}+\mathrm{CH}_{2}^{*} \rightleftarrows \mathrm{CH}_{3}^{*}+^{*}$ & 0.49 & -0.03 \\
$\mathrm{H}^{*}+\mathrm{CH}_{3}^{*} \rightleftarrows \mathrm{CH}_{4}+^{*}+$ & 1.11 & -0.06 \\
\hline
\end{tabular}

(a)

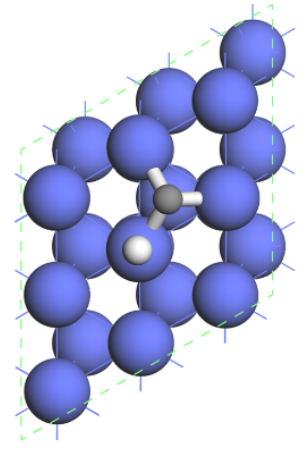

(b)

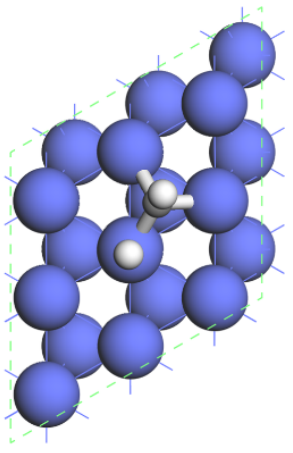

(c)

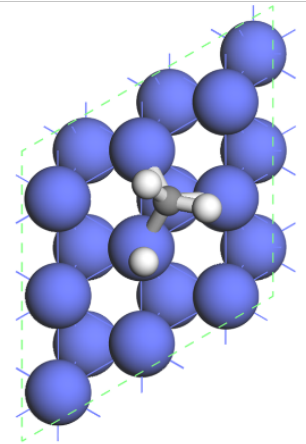

(d)

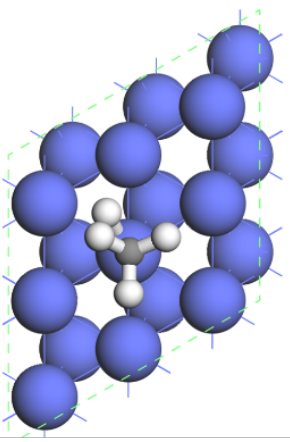

Figure S6. Top views of calculated transition state geometries of $\mathrm{C}_{1}$ hydrogenation to methane on $\mathrm{Co}(0001)$. (a) $\mathrm{TS}_{\mathrm{C}+\mathrm{H}(\mathrm{CH})}$; (b) $\mathrm{TS}_{\mathrm{CH}+\mathrm{H}\left(\mathrm{CH}_{2}\right)}$; (c) $\mathrm{TS}_{\mathrm{CH} 2+\mathrm{H}\left(\mathrm{CH}_{3}\right)}$; and (d) $\mathrm{TS}_{\mathrm{CH}^{3}+\mathrm{H}\left(\mathrm{CH}_{4}\right)}$. 
Table S7. Distances at the transition states of $\mathrm{C}_{1}$ hydrogenation to methane on $\operatorname{Co}(0001)$.

\begin{tabular}{lll}
\hline & Transition State & Distance $(\AA)$ \\
\hline (a) & $\mathrm{TS}_{\mathrm{C}+\mathrm{H}(\mathrm{CH})}$ & 1.68 \\
(b) & $\mathrm{TS}_{\mathrm{CH}+\mathrm{H}(\mathrm{CH} 2)}$ & 1.61 \\
(c) & $\mathrm{TS}_{\mathrm{CH} 2+\mathrm{H}(\mathrm{CH} 3)}$ & 1.75 \\
(d) & $\mathrm{TS}_{\mathrm{CH} 3+\mathrm{H}(\mathrm{CH} 4)}$ & 1.61 \\
\hline
\end{tabular}

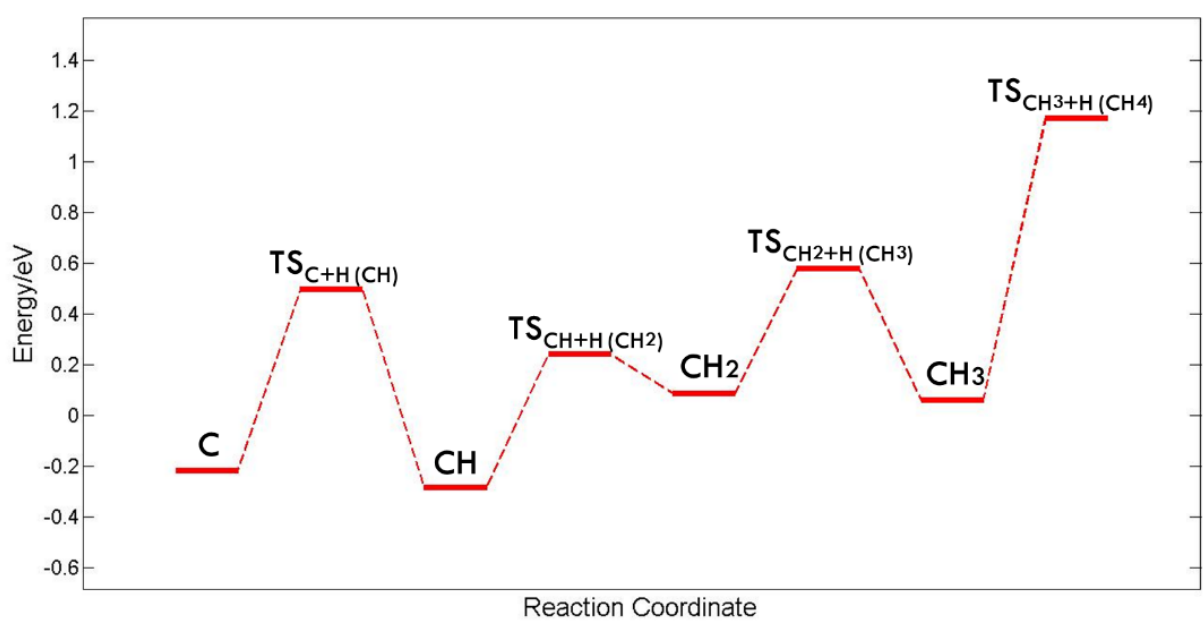

Figure S7. Energy profile of $\mathrm{C}_{1}$ hydrogenation to methane on $\mathrm{Co}(0001)$. The path is $\mathrm{C}(\mathrm{ad})+4 \mathrm{H}(\mathrm{ad})$ $\rightarrow \mathrm{TS}_{\mathrm{C}+\mathrm{H}(\mathrm{CH})}(\mathrm{ad})+3 \mathrm{H}(\mathrm{ad}) \rightarrow \mathrm{CH}(\mathrm{ad})+3 \mathrm{H}(\mathrm{ad}) \rightarrow \mathrm{TS}_{\mathrm{CH}+\mathrm{H}(\mathrm{CH} 2)}+2 \mathrm{H}(\mathrm{ad}) \rightarrow \mathrm{CH}_{2}(\mathrm{ad})+2 \mathrm{H}(\mathrm{ad}) \rightarrow \mathrm{TS}_{\mathrm{CH} 2+\mathrm{H}}$ $\left(\mathrm{CH}_{3}\right)(\mathrm{ad})+\mathrm{H}(\mathrm{ad}) \rightarrow \mathrm{CH}_{3}(\mathrm{ad})+\mathrm{H}(\mathrm{ad}) \rightarrow \mathrm{TS}_{\mathrm{CH}^{3}+\mathrm{H}\left(\mathrm{CH}_{4}\right)}(\mathrm{ad})$.

\section{5 $\mathrm{C}_{1}+\mathrm{C}_{1}$ Coupling Reactions}

There are nine coupling pathways for $\mathrm{C}_{1}$ and $\mathrm{C}_{1}$ coupling and the calculated forward reaction barriers and reaction energies are listed in Table S8. The calculated barriers are consistent with the literature..$^{10}$ Frequency analyses were applied to ensure that the correct transition states were found in the DFT calculations. The corresponding transition state structures are displayed in Figure S8 and the distances of transition states are listed in Table S9. Based on the stabilities of species and the corresponding barriers we converted data into the energy profile in Figure S9. We can clearly find that the most favoured coupling pathway is $\mathrm{CH}+\mathrm{CH}$ and other coupling pathways are preferred. Although the coupling of $\mathrm{CH}_{2}+\mathrm{CH}_{2}$ is facile, the monomer of $\mathrm{CH}_{2}$ is unstable on the surface which is shown in Figure S9. 
Table S8. The forward reaction barriers and reaction energies of of $\mathrm{C}_{1}+\mathrm{C}_{1}$ coupling steps.

\begin{tabular}{|c|c|c|}
\hline Elementary reaction & Forward barrier $(\mathrm{eV})$ & Reaction energy $(\mathrm{eV})$ \\
\hline $\mathrm{C}^{*}+\mathrm{C}^{*} \rightleftarrows \mathrm{CC}^{*}+*$ & 1.38 & -0.27 \\
\hline $\mathrm{C}^{*}+\mathrm{CH}^{*} \rightleftarrows \mathrm{CCH}^{*}+*$ & 1.03 & -0.51 \\
\hline $\mathrm{C}^{*}+\mathrm{CH}_{2} * \rightleftarrows \mathrm{CCH}_{2} * *$ & 1.02 & -0.42 \\
\hline $\mathrm{C}^{*}+\mathrm{CH}_{3} * \rightleftarrows \mathrm{CCH}_{3} *+*$ & 1.16 & -0.39 \\
\hline $\mathrm{CH}^{*}+\mathrm{CH}^{*} \rightleftarrows \mathrm{CHCH}^{*}+*$ & 0.70 & -0.53 \\
\hline $\mathrm{CH}^{*}+\mathrm{CH}_{2} * \rightleftarrows \mathrm{CHCH}_{2} *+*$ & 0.91 & -0.04 \\
\hline $\mathrm{CH}^{*}+\mathrm{CH}_{3} * \rightleftarrows \mathrm{CHCH}_{3} *+*$ & 1.18 & 0.30 \\
\hline 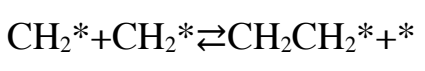 & 0.51 & -0.34 \\
\hline $\mathrm{CH}_{2} *+\mathrm{CH}_{3} * \rightleftarrows \mathrm{CH}_{2} \mathrm{CH}_{3} *+*$ & 1.03 & 0.18 \\
\hline
\end{tabular}




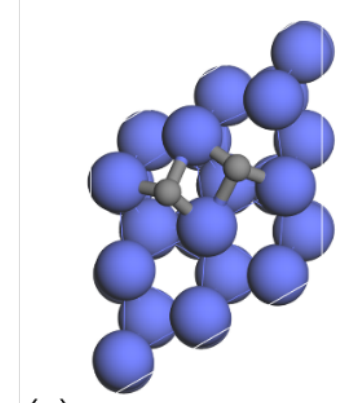

(a)

(b)

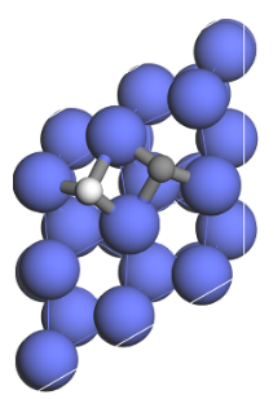

(c)
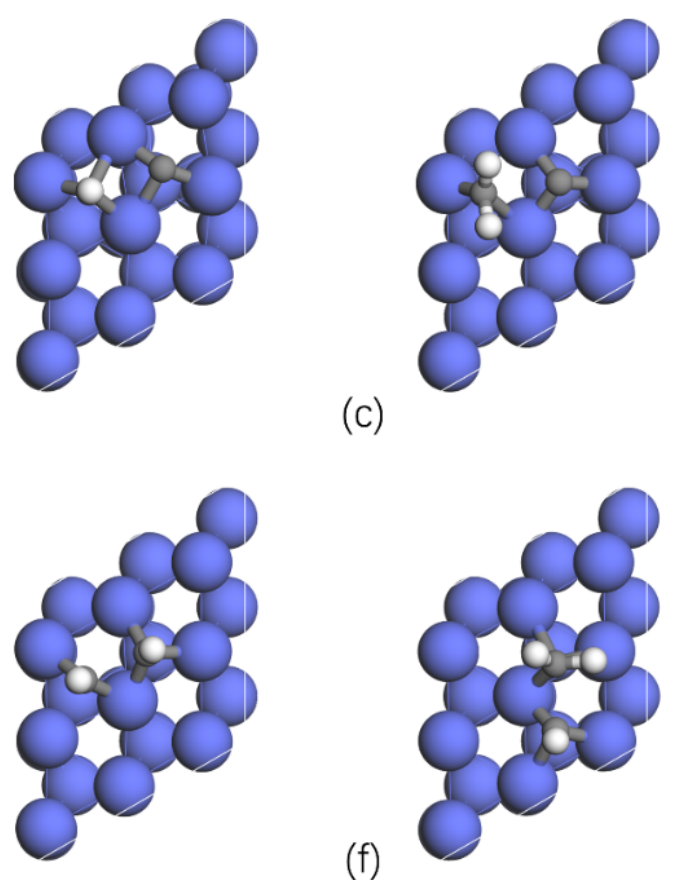

(f)

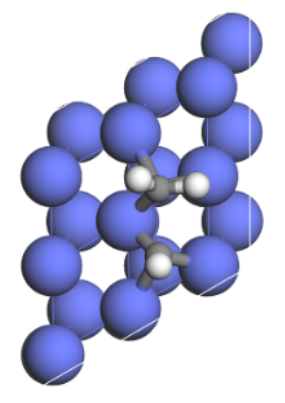

(h)

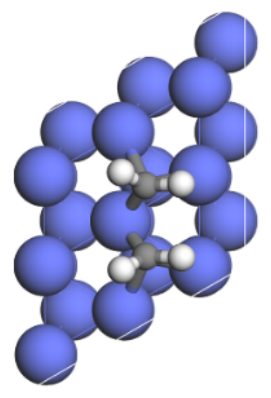

(i)

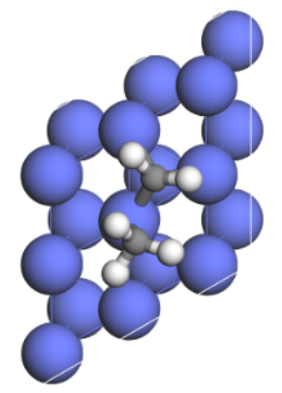

Figure S8. Top view of calculated transition state geometries of $\mathrm{C}_{1}+\mathrm{C}_{1}$ coupling reactions on the flat cobalt surface. (a) $\mathrm{TS}_{\mathrm{C}+\mathrm{C}}$; (b) $\mathrm{TS}_{\mathrm{C}+\mathrm{CH}}$; (c) $\mathrm{TS}_{\mathrm{C}+\mathrm{CH} 2}$; (d) $\mathrm{TS}_{\mathrm{C}+\mathrm{CH} 3}$; (e) $\mathrm{TS}_{\mathrm{CH}+\mathrm{CH}}$; (f) $\mathrm{TS}_{\mathrm{CH}+\mathrm{CH} 2}$; (g) $\mathrm{TS}_{\mathrm{CH}+\mathrm{CH} 3}$; (h) $\mathrm{TS}_{\mathrm{CH} 2+\mathrm{CH} 2}$; (i) $\mathrm{TS}_{\mathrm{CH} 2+\mathrm{CH} 3}$. 
Table S9. Distances at the transition states of $\mathrm{C}_{1}+\mathrm{C}_{1}$ coupling reactions on $\mathrm{Co}(0001)$.

\begin{tabular}{lll}
\hline & Transition State & Distance $(\AA)$ \\
\hline (a) & $\mathrm{TS}_{\mathrm{C}+\mathrm{C}(\mathrm{CC})}$ & 2.12 \\
(b) & $\mathrm{TS}_{\mathrm{C}+\mathrm{CH}(\mathrm{CCH})}$ & 2.22 \\
(c) & $\mathrm{TS}_{\mathrm{C}+\mathrm{CH}_{2}(\mathrm{CCH} 2)}$ & 2.28 \\
(d) & $\mathrm{TS}_{\mathrm{C}+\mathrm{CH}_{3}\left(\mathrm{CCH}_{3}\right)}$ & 2.1 \\
(e) & $\mathrm{TS}_{\mathrm{CH}+\mathrm{CH}(\mathrm{CHCH})}$ & 1.97 \\
(f) & $\mathrm{TS}_{\mathrm{CH}+\mathrm{CH}_{2}(\mathrm{CHCH} 2)}$ & 1.93 \\
(g) & $\mathrm{TS}_{\mathrm{CH}+\mathrm{CH}_{3}(\mathrm{CHCH})}$ & 1.98 \\
(h) & $\mathrm{TS}_{\mathrm{CH}_{2}+\mathrm{CH}_{2}\left(\mathrm{CH}_{2} \mathrm{CH}_{2}\right)}$ & 2.04 \\
(i) & $\mathrm{TS}_{\mathrm{CH}_{2}+\mathrm{CH}_{3}\left(\mathrm{CH}_{2} \mathrm{CH} 3\right)}$ & 2.05 \\
\hline
\end{tabular}

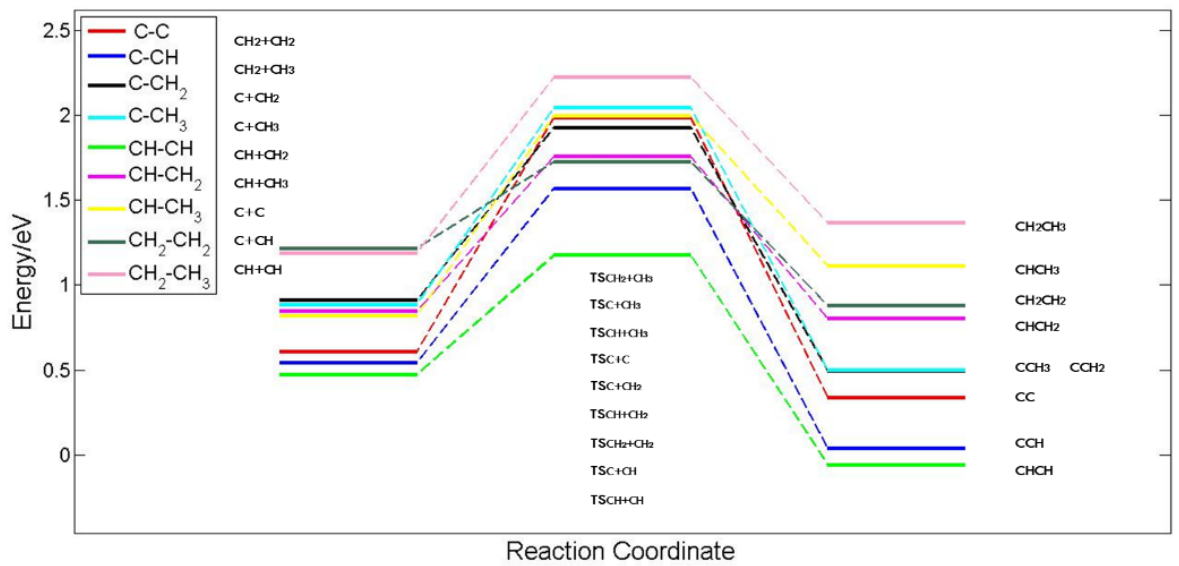

Figure S9. Energy profiles of $\mathrm{C}_{1}+\mathrm{C}_{1}$ coupling reactions on $\mathrm{Co}(0001)$. The path is $\mathrm{CH}_{\mathrm{x}}(\mathrm{ad})+\mathrm{CH}_{\mathrm{y}}(\mathrm{ad})+(5-\mathrm{x}-\mathrm{y}) \mathrm{H}(\mathrm{ad}) \rightarrow \mathrm{TS}_{\mathrm{CHx}+\mathrm{CHy}}(\mathrm{ad})+(5-\mathrm{x}-\mathrm{y}) \mathrm{H}(\mathrm{ad}) \rightarrow \mathrm{CH}_{\mathrm{x}} \mathrm{CH}_{\mathrm{y}}(\mathrm{ad})+(5-\mathrm{x}-\mathrm{y}) \mathrm{H}(\mathrm{ad})$, where $\mathrm{x}, \mathrm{y}=0,1,2,3 . \mathrm{x}+\mathrm{y}=5$.

\section{6 $\mathrm{C}_{2}$ Hydrogenation Reactions}

There are twelve hydrogenation reactions for $\mathrm{C}_{2}$ species, which are listed in Table $\mathrm{S} 10$. Cheng et $\mathrm{al}^{12}$ only calculated three hydrogenations, namely $\mathrm{CCH}_{3}+\mathrm{H}, \mathrm{CHCH}_{3}+\mathrm{H}, \mathrm{CH}_{2} \mathrm{CH}_{3}+\mathrm{H}$. In this work, all the twelve hydrogenation reactions were searched using the constrained optimization scheme. The structures of the transition states are shown in Figure S10 and the corresponding distances of the transition states are listed in Table S11. It should be mentioned that all the barriers of 
hydrogenation reactions for $\mathrm{C}_{2}$ are around $0.6 \mathrm{eV}$ except for $\mathrm{CHCH}$ hydrogenation to $\mathrm{CHCH}_{2}$ which has the barrier of $1.16 \mathrm{eV}$.

Table S10. The forward reaction barriers and reaction energies of $\mathrm{C}_{2}$ hydrogenation reactions.

\begin{tabular}{|c|c|c|}
\hline Elementary reaction & $\begin{array}{l}\text { Forward reaction } \\
\text { barrier }(\mathrm{eV})\end{array}$ & Reaction energy $(\mathrm{eV})$ \\
\hline $\mathrm{CC}^{*}+\mathrm{H}^{*} \rightleftarrows \mathrm{CCH}^{*}+*$ & 0.66 & -0.30 \\
\hline $\mathrm{CCH}^{*}+\mathrm{H}^{*} \rightleftarrows \mathrm{CCH}_{2}^{*}+*$ & 0.78 & 0.46 \\
\hline $\mathrm{CCH}^{*}+\mathrm{H}^{*} \rightleftarrows \mathrm{CHCH}^{*}+^{*}$ & 0.62 & -0.09 \\
\hline $\mathrm{CCH}_{2} *+\mathrm{H}^{*} \rightleftarrows \mathrm{CCH}_{3} *+*$ & 0.48 & 0.003 \\
\hline $\mathrm{CCH}_{2}{ }^{*}+\mathrm{H}^{*} \rightleftarrows \mathrm{CHCH}_{2}{ }^{*} *$ & 0.51 & 0.31 \\
\hline $\mathrm{CCH}_{3} *+\mathrm{H}^{*} \rightleftarrows \mathrm{CHCH}_{3}{ }^{*} *$ & 0.67 & 0.62 \\
\hline $\mathrm{CH}_{2} \mathrm{CH}_{2} *+\mathrm{H}^{*} \rightleftarrows \mathrm{CH}_{2} \mathrm{CH}_{3} *+*$ & 0.50 & 0.49 \\
\hline $\mathrm{CH}_{2} \mathrm{CH}_{3} *+\mathrm{H}^{*} \rightleftarrows \mathrm{CH}_{3} \mathrm{CH}_{3}+^{*}+*$ & 0.82 & -0.30 \\
\hline $\mathrm{CHCH}^{*}+\mathrm{H}^{*} \rightleftarrows \mathrm{CHCH}_{2}+^{*}$ & 1.16 & 0.86 \\
\hline $\mathrm{CHCH}_{2} *+\mathrm{H}^{*} \rightleftarrows \mathrm{CH}_{2} \mathrm{CH}_{2} *+*$ & 0.46 & 0.07 \\
\hline $\mathrm{CHCH}_{2}{ }^{*}+\mathrm{H}^{*} \rightleftarrows \mathrm{CHCH}_{3}{ }^{*} *$ & 0.50 & 0.31 \\
\hline $\mathrm{CHCH}_{3} *+\mathrm{H}^{*} \rightleftarrows \mathrm{CH}_{2} \mathrm{CH}_{3} *+*$ & 0.56 & 0.25 \\
\hline
\end{tabular}


(a)

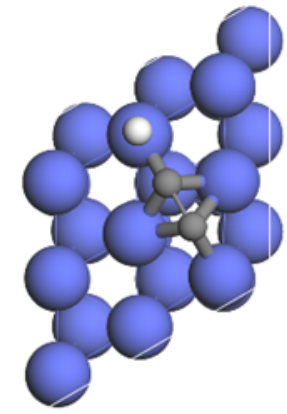

(d)

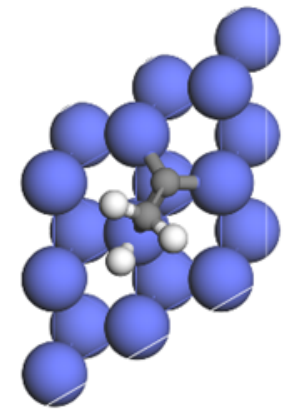

(g)

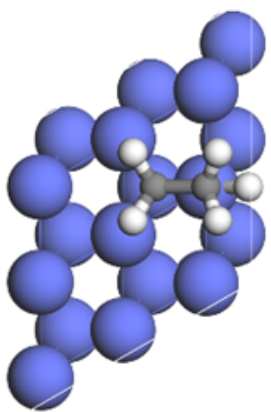

(h)

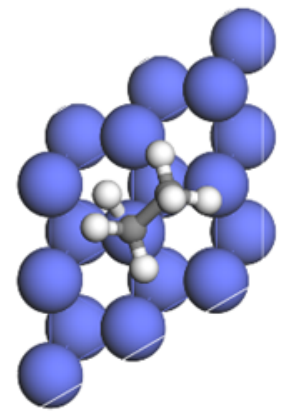

$(\mathrm{k})$

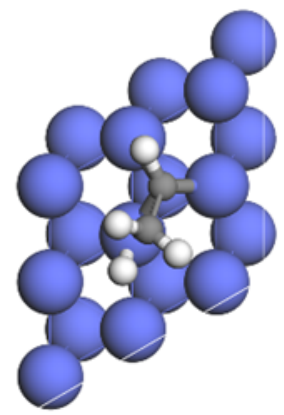

(j)

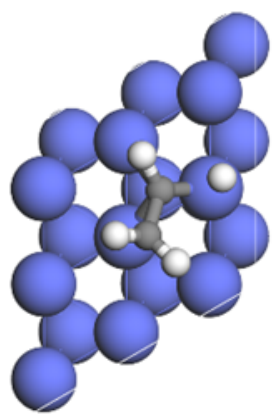

(c)

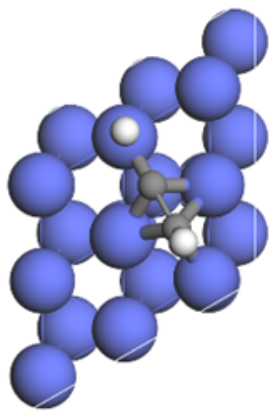

(f)

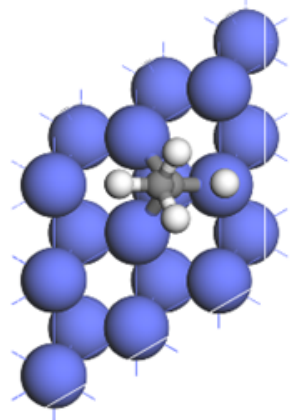

(i)

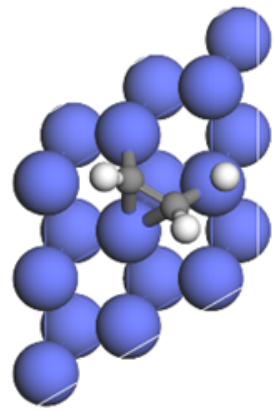

(l)

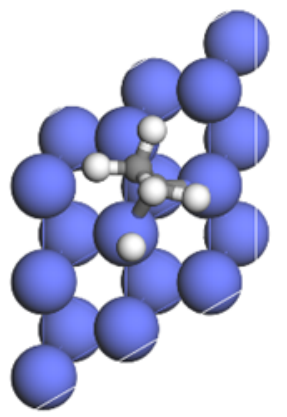

Figure S10. Top views of the transition state geometries of $\mathrm{C}_{2}$ hydrogenation reactions on $\mathrm{Co}(0001)$. (a) $\mathrm{TS}_{\mathrm{CC}+\mathrm{H}(\mathrm{CCH})}$; (b) $\mathrm{TS}_{\mathrm{CCH}+\mathrm{H}(\mathrm{CCH})}$; (c) $\mathrm{TS}_{\mathrm{CCH}+\mathrm{H}(\mathrm{CHCH})}$; (d) $\mathrm{TS}_{\mathrm{CCH}+\mathrm{H}(\mathrm{CCH} 3)}$; (e) $\mathrm{TS}_{\mathrm{CCH}_{2}+\mathrm{H}\left(\mathrm{CHCH}_{2}\right)}$; 
(f) $\mathrm{TS}_{\mathrm{CCH}^{3}+\mathrm{H}\left(\mathrm{CHCH}_{3}\right)} ;\left(\right.$ g) $\mathrm{TS}_{\mathrm{CH}_{2} \mathrm{CH}_{2}+\mathrm{H}\left(\mathrm{CH}_{2} \mathrm{CH}_{3}\right)} ;$ (h) $\mathrm{TS}_{\mathrm{CH}_{2} \mathrm{CH}_{3}+\mathrm{H}\left(\mathrm{CH}_{3} \mathrm{CH}_{3}\right)}$; (i) $\mathrm{TS}_{\mathrm{CHCH}^{+}\left(\mathrm{CHCH}_{2}\right)} ;$ (j) $\mathrm{TS}_{\mathrm{CHCH}_{2}+\mathrm{H}}$ ( $\left.\mathrm{CH}_{2} \mathrm{CH} 2\right) ;(\mathrm{k}) \mathrm{TS}_{\mathrm{CHCH}_{2}+\mathrm{H}\left(\mathrm{CHCH}_{3}\right)}$; and (l) $\mathrm{TS}_{\left.\mathrm{CHCH}_{3}+\mathrm{H}_{(\mathrm{CH}} \mathrm{CH}_{3}\right)}$.

Table S11. Distances at the transition states of $\mathrm{C}_{2}$ hydrogenation reactions on $\mathrm{Co}(0001)$.

\begin{tabular}{|c|c|c|}
\hline & Transition State & Distance $(\AA)$ \\
\hline (a) & $\mathrm{TS}_{\mathrm{CC}+\mathrm{H}(\mathrm{CCH})}$ & 1.7 \\
\hline (b) & $\mathrm{TS}_{\mathrm{CCH}+\mathrm{H}\left(\mathrm{CCH}_{2}\right)}$ & 1.35 \\
\hline (c) & $\mathrm{TS}_{\mathrm{CCH}+\mathrm{H}(\mathrm{CHCH})}$ & 1.71 \\
\hline (d) & $\mathrm{TS}_{\mathrm{CCH}_{2}+\mathrm{H}\left(\mathrm{CCH}_{3}\right)}$ & 1.58 \\
\hline (e) & $\mathrm{TS}_{\mathrm{CCH}_{2}+\mathrm{H}\left(\mathrm{CHCH}_{2}\right)}$ & 1.62 \\
\hline (f) & $\mathrm{TS}_{\mathrm{CCH} 3+\mathrm{H}\left(\mathrm{CHCH}_{3}\right)}$ & 1.5 \\
\hline$(g)$ & $\mathrm{TS}_{\mathrm{CH}_{2} \mathrm{CH}_{2}+\mathrm{H}\left(\mathrm{CH}_{2} \mathrm{CH}_{3}\right)}$ & 1.47 \\
\hline (h) & $\mathrm{TS}_{\mathrm{CH}_{2} \mathrm{CH}_{3}+\mathrm{H}\left(\mathrm{CH}_{3} \mathrm{CH}_{3}\right)}$ & 1.62 \\
\hline (i) & $\mathrm{TS}_{\mathrm{CHCH}+\mathrm{H}\left(\mathrm{CHCH}_{2}\right)}$ & 1.57 \\
\hline (j) & $\mathrm{TS}_{\mathrm{CHCH}_{2}+\mathrm{H}\left(\mathrm{CH}_{2} \mathrm{CH}_{2}\right)}$ & 1.7 \\
\hline$(\mathrm{k})$ & $\mathrm{TS}_{\mathrm{CHCH}_{2}+\mathrm{H}\left(\mathrm{CHCH}_{3}\right)}$ & 1.54 \\
\hline (1) & $\mathrm{TS}_{\mathrm{CHCH}_{3}+\mathrm{H}\left(\mathrm{CH}_{2} \mathrm{CH} 3\right)}$ & 1.71 \\
\hline
\end{tabular}

\subsection{CO and $\mathrm{C}_{1}$ Coupling Reactions}

Cheng et al. ${ }^{13}$ only calculated $\mathrm{CH}_{3}+\mathrm{CO}$ for the $\mathrm{CO}$ insertion mechanism and the reported barrier to be quite high. Some groups proposed that $\mathrm{CH}+\mathrm{CO}$ and $\mathrm{CH}_{2}+\mathrm{CO}$ may be possible pathways to form long chain hydrocarbons on $\mathrm{Co}(0001))^{14-16} \mathrm{We}$ listed three CO-insertion coupling pathways in Table S12 and the corresponding energy profiles are plotted in Figure S12. It is found that the coupling reactions of $\mathrm{CH}+\mathrm{CO}$ and $\mathrm{CH}_{2}+\mathrm{CO}$ are much easier than the coupling of $\mathrm{CH}_{3}+\mathrm{CO}$, which are $0.96 \mathrm{eV}$ and $0.79 \mathrm{eV}$, respectively. The calculated barrier of $\mathrm{CH}_{3}+\mathrm{CO}$ is very similar to that of Cheng et al. ${ }^{13}$ The structures of the transition states are shown in Figure S11 and the corresponding distances of the transition states are listed in the Table S13. 
Table S12. The forward reaction barriers and reaction energies of $\mathrm{CO}$ and $\mathrm{C}_{1}$ coupling reactions.

\begin{tabular}{lll}
\hline Elementary reaction & Forward barrier $(\mathrm{eV})$ & Reaction energy $(\mathrm{eV})$ \\
\hline $\mathrm{CH}^{*}+\mathrm{CO}^{*} \rightleftarrows \mathrm{CHCO}^{*}+*$ & 0.96 & 0.37 \\
$\mathrm{CH}_{2}^{*}+\mathrm{CO}^{*} \rightleftarrows \mathrm{CH}_{2} \mathrm{CO}^{*}+*$ & 0.79 & 0.73 \\
$\mathrm{CH}_{3}^{*}+\mathrm{CO}^{*} \rightleftarrows \mathrm{CH}_{3} \mathrm{CO}^{*}+*$ & 1.45 & 0.80 \\
\hline
\end{tabular}

(a)

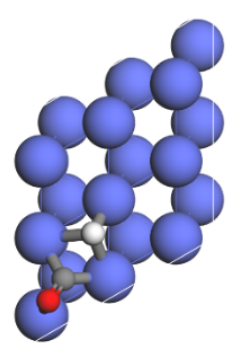

(b)

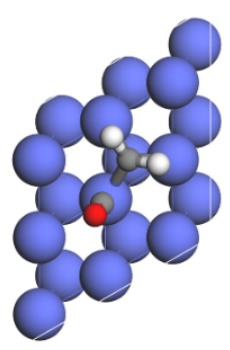

(c)

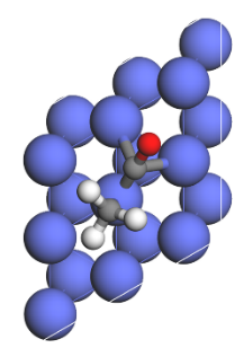

Figure S11. Top views of the calculated transition state geometries of $\mathrm{CO}$ and $\mathrm{C}_{1}$ coupling reactions on $\mathrm{Co}(0001)$. (a) $\mathrm{TS}_{\mathrm{CH}+\mathrm{CO}(\mathrm{CHCO})}$; (b) $\mathrm{TS}_{\mathrm{CH}^{2}+\mathrm{CO}(\mathrm{CH} 2 \mathrm{CO})}$; and (c) $\mathrm{TS}_{\mathrm{CH}_{3}+\mathrm{CO}\left(\mathrm{CH}_{3} \mathrm{CO}\right)}$.

Table S13. Distances at the transition states of $\mathrm{CO}$ and $\mathrm{C}_{1}$ coupling reactions on $\mathrm{Co}(0001)$.

\begin{tabular}{lll}
\hline & Transition State & Distance $(\AA)$ \\
\hline (a) & $\mathrm{TS}_{\mathrm{CH}+\mathrm{CO}(\mathrm{CHCO})}$ & 1.8 \\
(b) & $\mathrm{TS}_{\mathrm{CH} 2+\mathrm{CO}(\mathrm{CH} 2 \mathrm{CO})}$ & 1.77 \\
(c) & $\mathrm{TS}_{\mathrm{CH}+\mathrm{CO}(\mathrm{CH} 3 \mathrm{CO})}$ & 1.88 \\
\hline
\end{tabular}




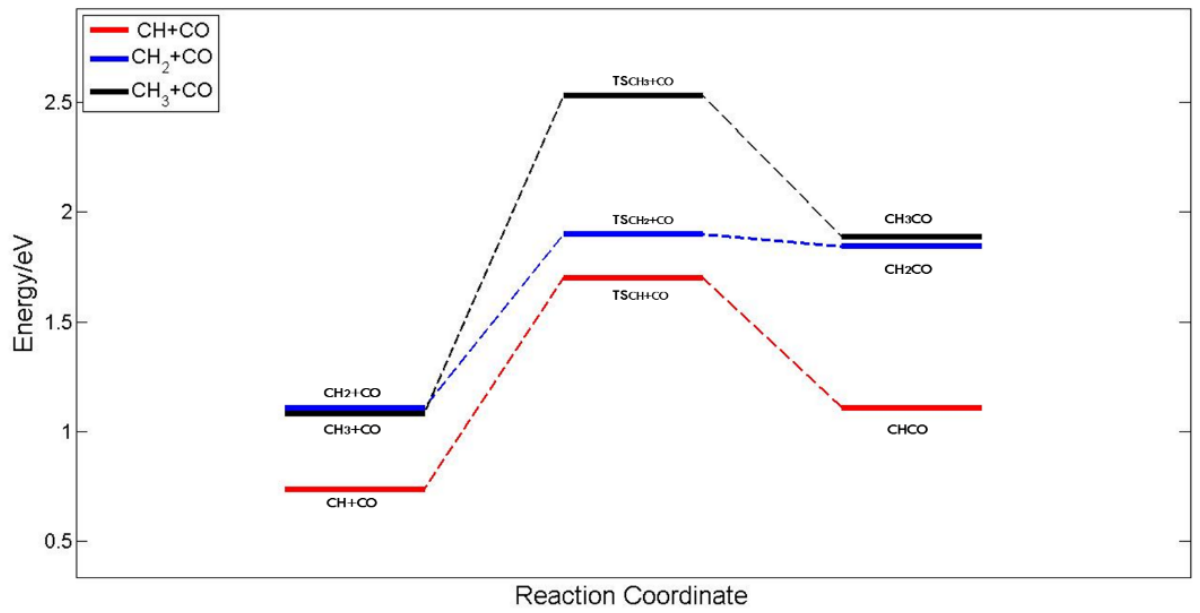

Figure S12. Energy profiles of $\mathrm{CO}$ and $\mathrm{C}_{1}$ coupling reactions on $\mathrm{Co}(0001)$. The path in red is $\mathrm{CH}(\mathrm{ad})+\mathrm{CO}(\mathrm{ad})+2 \mathrm{H}(\mathrm{ad}) \rightarrow \mathrm{TS}_{\mathrm{CH}+\mathrm{CO}}(\mathrm{ad})+2 \mathrm{H}(\mathrm{ad}) \rightarrow \mathrm{CHCO}(\mathrm{ad})+2 \mathrm{H}(\mathrm{ad})$. The path in blue is $\mathrm{CH}_{2}(\mathrm{ad})+\mathrm{CO}(\mathrm{ad})+\mathrm{H}(\mathrm{ad}) \rightarrow \mathrm{TS}_{\mathrm{CH} 2+\mathrm{CO}}(\mathrm{ad})+\mathrm{H}(\mathrm{ad}) \rightarrow \mathrm{CH}_{2} \mathrm{CO}(\mathrm{ad})+\mathrm{H}(\mathrm{ad})$. The path in black is $\mathrm{CH}_{3}(\mathrm{ad})+\mathrm{CO}(\mathrm{ad}) \rightarrow \mathrm{TS}_{\mathrm{CH}+\mathrm{CO}}(\mathrm{ad}) \rightarrow \mathrm{CH}_{3} \mathrm{CO}(\mathrm{ad})$.

\section{8 $\mathrm{C}_{1}$ and $\mathrm{OH}$ Coupling Reactions}

Three $\mathrm{C}_{1}$ and $\mathrm{OH}$ coupling reactions were calculated and the corresponding forward reaction barriers and reaction energies are listed in Table $\mathrm{S} 14$ and the energy profiles are plotted in Figure S14. Because of the repulsion effect of $\mathrm{CH}_{3}$ on $\mathrm{OH}$, which can be seen in the transition state in Figure S13, the coupling barrier of $\mathrm{CH}_{3}$ and $\mathrm{OH}$ is much higher than the couplings of $\mathrm{CH}_{2}{ }^{*}+\mathrm{OH}^{*}$ and $\mathrm{CH}^{*}+\mathrm{OH}^{*}$ and all the reactions are endothermic. The structures of the transition states are shown in Figure S13 and the corresponding distances of the transition states are listed in the Table S15.

Table S14. The forward reaction barriers and reaction energies of $\mathrm{C}_{1}$ and $\mathrm{OH}$ coupling reactions.

\begin{tabular}{lll}
\hline Elementary reaction & Forward barrier $(\mathrm{eV})$ & Reaction energy $(\mathrm{eV})$ \\
\hline $\mathrm{CH}_{3}{ }^{*}+\mathrm{OH}^{*} \rightleftarrows \mathrm{CH}_{3} \mathrm{OH}+*+^{*}$ & 2.45 & 0.94 \\
$\mathrm{CH}_{2}{ }^{*}+\mathrm{OH}^{*} \rightleftarrows \mathrm{CH}_{2} \mathrm{OH}^{*}+^{*}$ & 1.45 & 1.04 \\
$\mathrm{CH}^{*}+\mathrm{OH}^{*} \rightleftarrows \mathrm{CHOH}^{*}+$ & 1.68 & 1.09 \\
\hline
\end{tabular}


(a)

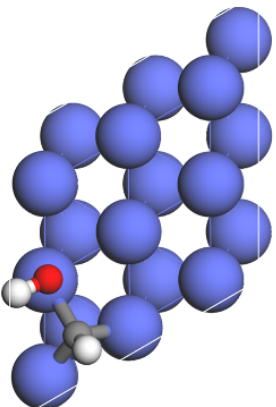

(b)

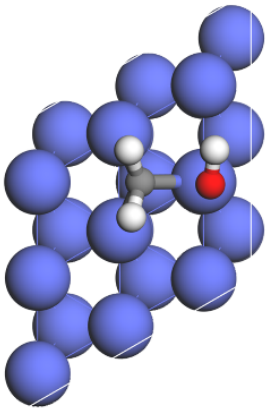

(c)

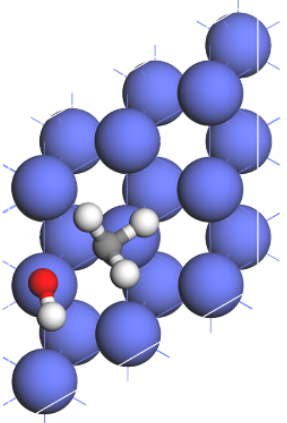

Figure S13. Top views of the calculated transition state geometries of $\mathrm{C}_{1}$ and $\mathrm{OH}$ coupling reactions on $\mathrm{Co}(0001)$. (a) $\mathrm{TS}_{\mathrm{CH}+\mathrm{OH}(\mathrm{CHOH})}$; (b) $\mathrm{TS}_{\mathrm{CH}^{2}+\mathrm{OH}\left(\mathrm{CH}_{2} \mathrm{OH}\right)}$; and (c) $\mathrm{TS}_{\mathrm{CH}^{3}+\mathrm{OH}\left(\mathrm{CH}_{3} \mathrm{OH}\right)}$.

Table S15. Distances at the transition states of $\mathrm{C}_{1}$ and $\mathrm{OH}$ coupling reactions on $\mathrm{Co}(0001)$.

\begin{tabular}{lll}
\hline & Transition State & Distance $(\AA)$ \\
\hline (a) & $\mathrm{TS}_{\mathrm{CH}+\mathrm{OH}}$ & 1.87 \\
(b) & $\mathrm{TS}_{\mathrm{CH} 2+\mathrm{OH}}$ & 2.01 \\
(c) & $\mathrm{TS}_{\mathrm{CH} 3+\mathrm{OH}}$ & 1.98 \\
\hline
\end{tabular}

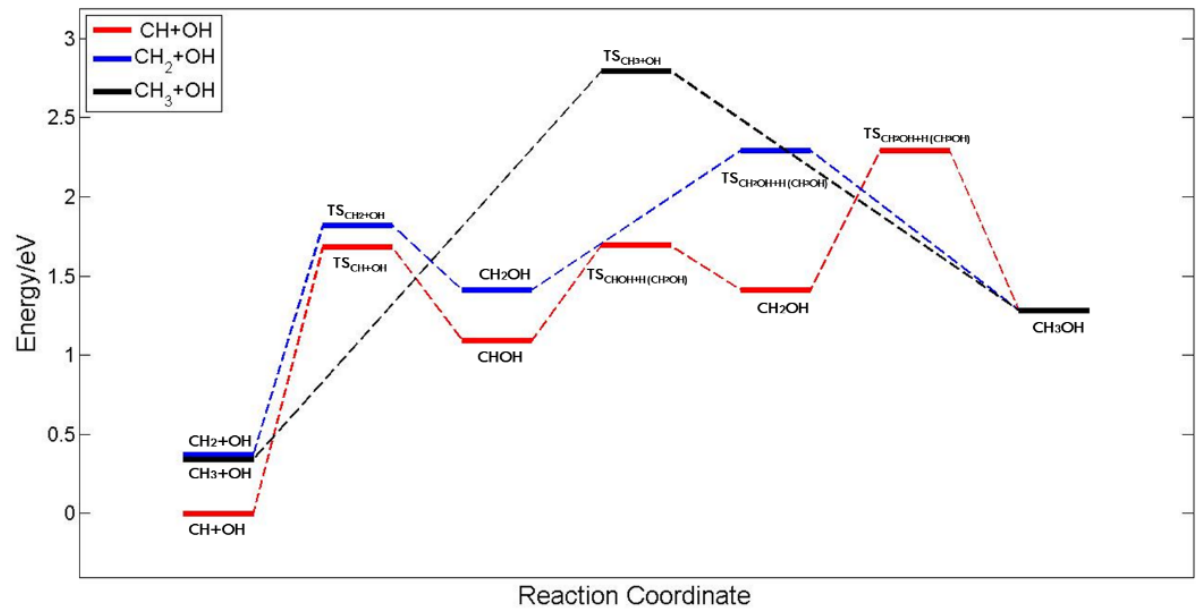

Figure S14. Energy profiles of $\mathrm{C}_{1}$ and $\mathrm{OH}$ coupling reactions on $\mathrm{Co}(0001)$. The path in red is $\mathrm{CH}(\mathrm{ad})+\mathrm{OH}(\mathrm{ad})+2 \mathrm{H}(\mathrm{ad}) \rightarrow \mathrm{TS}_{\mathrm{CH}+\mathrm{OH}}(\mathrm{ad})+2 \mathrm{H}(\mathrm{ad}) \rightarrow \mathrm{CHOH}(\mathrm{ad})+2 \mathrm{H}(\mathrm{ad}) \rightarrow \mathrm{TS}_{\mathrm{CHOH}+\mathrm{H}}$ $\left({ }_{(\mathrm{CH}} \mathrm{OH}\right)(\mathrm{ad})+\mathrm{H}(\mathrm{ad}) \rightarrow \mathrm{CH}_{2} \mathrm{OH}(\mathrm{ad})+\mathrm{H}(\mathrm{ad}) \rightarrow \mathrm{CH}_{3} \mathrm{OH}(\mathrm{gas})$. The path in blue is $\mathrm{CH}_{2}(\mathrm{ad})+$ 
$\mathrm{OH}(\mathrm{ad})+\mathrm{H}(\mathrm{ad}) \rightarrow \mathrm{TS}_{\mathrm{CH}^{2}+\mathrm{OH}(\mathrm{CH} 2 \mathrm{OH})}(\mathrm{ad})+\mathrm{H}(\mathrm{ad}) \rightarrow \mathrm{CH}_{2} \mathrm{OH}(\mathrm{ad})+\mathrm{H}(\mathrm{ad}) \rightarrow \mathrm{CH}_{3} \mathrm{OH}(\mathrm{gas})$. The path in black is $\mathrm{CH}_{3}(\mathrm{ad})+\mathrm{OH}(\mathrm{ad}) \rightarrow \mathrm{CH}_{3} \mathrm{OH}(\mathrm{gas})$.

\section{9 $\mathrm{CH}_{\mathrm{x}} \mathrm{CH}_{\mathrm{y}} \mathrm{O}$ Hydrogenations}

In our work, we found 15 elementary steps of $\mathrm{CH}_{\mathrm{x}} \mathrm{CH}_{\mathrm{y}} \mathrm{O}$ hydrogenation reactions, and the calculated reaction barriers and reaction energies are listed in Table S16. Most of $\mathrm{CH}_{\mathrm{x}} \mathrm{CH}_{\mathrm{y}} \mathrm{O}$ hydrogenations are endothermic. It should be mentioned that $\mathrm{CHO}^{*}+\mathrm{H}^{*} \rightleftarrows \mathrm{CHOH}^{*}$, $\mathrm{CH}_{2} \mathrm{O}^{*}+\mathrm{H}^{*} \rightleftarrows \mathrm{CH}_{2} \mathrm{OH}^{*}+^{*}, \mathrm{CH}_{3} \mathrm{O}^{*}+\mathrm{H}^{*} \rightleftarrows \mathrm{CH}_{3} \mathrm{OH}+^{*}+*, \mathrm{CHCO}^{*}+\mathrm{H}^{*} \rightleftarrows \mathrm{CHCHO}^{*}+^{*}$, $\mathrm{CH}_{2} \mathrm{CHO}^{*}+\mathrm{H}^{*} \rightleftarrows \mathrm{CH}_{3} \mathrm{CHO}^{*}+*$ are much higher than other hydrogenations and the corresponding barriers are $1.11 \mathrm{eV}, 1.02 \mathrm{eV}, 1.66 \mathrm{eV}, 1.27 \mathrm{eV}, 1.26 \mathrm{eV}$, respectively. The rest of barriers are approximately $0.6 \mathrm{eV}$ which are very similar to the $\mathrm{C}_{\mathrm{x}} \mathrm{H}_{\mathrm{y}}$ hydrogenations.

Table S16. The forward reaction barriers and reaction energies of elementary steps of $\mathrm{CH}_{\mathrm{x}} \mathrm{CH}_{\mathrm{y}} \mathrm{O}$ hydrogenation reactions.

\begin{tabular}{lll}
\hline Elementary reaction & Forward barrier $(\mathrm{eV})$ & Reaction energy $(\mathrm{eV})$ \\
\hline $\mathrm{CHO}^{*}+\mathrm{H}^{*} \rightleftarrows \mathrm{CHOH}^{*}+^{*}$ & 1.10 & 0.59 \\
$\mathrm{CHO}^{*}+\mathrm{H}^{*} \rightleftarrows \mathrm{CH}_{2} \mathrm{O}^{*}+^{*}$ & 0.60 & 0.29 \\
$\mathrm{CH}_{2} \mathrm{O}^{*}+\mathrm{H}^{*} \rightleftarrows \mathrm{CH}_{2} \mathrm{OH}^{*}+^{*}$ & 1.02 & 0.62 \\
$\mathrm{CH}_{2} \mathrm{O}^{*}+\mathrm{H}^{*} \rightleftarrows \mathrm{CH}_{3} \mathrm{O}^{*}+^{*}$ & 0.55 & -0.09 \\
$\mathrm{CH}_{3} \mathrm{O}^{*}+\mathrm{H}^{*} \rightleftarrows \mathrm{CH}_{3} \mathrm{OH}+^{*}+^{*}$ & 1.66 & 0.58 \\
$\mathrm{CHCO}^{*}+\mathrm{H}^{*} \rightleftarrows \mathrm{CH}_{2} \mathrm{CO}^{*}+*$ & 0.76 & 0.74 \\
$\mathrm{CHCO}^{*}+\mathrm{H}^{*} \rightleftarrows \mathrm{CHCHO}^{*}+$ & 1.27 & 0.59 \\
$\mathrm{CH}_{2} \mathrm{CO}^{*}+\mathrm{H}^{*} \rightleftarrows \mathrm{CH}_{2} \mathrm{CHO}^{*}+*$ & 0.41 & -0.08 \\
$\mathrm{CH}_{2} \mathrm{CO}^{*}+\mathrm{H}^{*} \rightleftarrows \mathrm{CH}_{3} \mathrm{CO}^{*}+*$ & 0.52 & 0.04 \\
$\mathrm{CHCHO}^{*}+\mathrm{H}^{*} \rightleftarrows \mathrm{CH}_{2} \mathrm{CHO}^{*}+*$ & 0.45 & 0.06 \\
$\mathrm{CH}_{2} \mathrm{OH}^{*}+\mathrm{H}^{*} \rightleftarrows \mathrm{CH}_{3} \mathrm{OH}^{*}+*$ & 0.88 & -0.13 \\
$\mathrm{COH}^{*}+\mathrm{H}^{*} \rightleftarrows \mathrm{CHOH}^{*}+$ & 0.73 & 0.72 \\
$\mathrm{CHOH}^{*}+\mathrm{H}^{*} \rightleftarrows \mathrm{CH}_{2} \mathrm{OH}^{*}+*$ & 0.60 & 0.32 \\
$\mathrm{CH}_{2} \mathrm{CHO}^{*}+\mathrm{H}^{*} \rightleftarrows \mathrm{CH}_{3} \mathrm{CHO}^{*}+*$ & 1.26 & 0.56
\end{tabular}


$\mathrm{CH}_{3} \mathrm{CO}^{*}+\mathrm{H}^{*} \rightleftarrows \mathrm{CH}_{3} \mathrm{CHO}^{*}+* \quad 0.50$

Table S17. Distances at the transition states of $\mathrm{CH}_{x} \mathrm{CH}_{y} \mathrm{O}$ hydrogenations on $\mathrm{Co}(0001)$.

\begin{tabular}{|c|c|c|}
\hline & Transition State & Distance $(\AA)$ \\
\hline (a) & $\mathrm{TS}_{\mathrm{CHO}+\mathrm{H}(\mathrm{CHOH})}$ & 1.36 \\
\hline (b) & $\mathrm{TS}_{\mathrm{CHO}+\mathrm{H}\left(\mathrm{CH}_{2} \mathrm{O}\right)}$ & 1.64 \\
\hline (c) & $\mathrm{TS}_{\mathrm{CH}_{2} \mathrm{O}+\mathrm{H}\left(\mathrm{CH}_{2} \mathrm{OH}\right)}$ & 1.37 \\
\hline (d) & $\mathrm{TS}_{\mathrm{CH}_{2} \mathrm{O}+\mathrm{H}(\mathrm{CH} 3 \mathrm{O})}$ & 1.57 \\
\hline (e) & $\mathrm{TS}_{\mathrm{CH} 3 \mathrm{O}+\mathrm{H}(\mathrm{CH} 3 \mathrm{OH})}$ & 1.43 \\
\hline (f) & $\mathrm{TS}_{\mathrm{CHCO}+\mathrm{H}\left(\mathrm{CH}_{2} \mathrm{CO}\right)}$ & 1.41 \\
\hline (g) & $\mathrm{TS}_{\mathrm{CHCO}+\mathrm{H} \text { (СHCHO) }}$ & 1.4 \\
\hline (h) & $\mathrm{TS}_{\mathrm{CH}_{2} \mathrm{CO}+\mathrm{H}\left(\mathrm{CH}_{2} \mathrm{CHO}\right)}$ & 1.62 \\
\hline (i) & $\mathrm{TS}_{\mathrm{CH}_{2} \mathrm{CO}+\mathrm{H}\left(\mathrm{CH}_{3} \mathrm{CO}\right)}$ & 1.56 \\
\hline (j) & $\mathrm{TS}_{\mathrm{CHCHO}+\mathrm{H}\left(\mathrm{CH}_{2} \mathrm{CHO}\right)}$ & 1.7 \\
\hline$(\mathrm{k})$ & $\mathrm{TS}_{\mathrm{CH}_{2} \mathrm{OH}+\mathrm{H}(\mathrm{CH} 3 \mathrm{OH})}$ & 1.57 \\
\hline (1) & $\mathrm{TS}_{\mathrm{COH}+\mathrm{H}(\mathrm{CHOH})}$ & 1.43 \\
\hline (m) & $\mathrm{TS}_{\mathrm{CHOH}+\mathrm{H}\left(\mathrm{CH}_{2} \mathrm{OH}\right)}$ & 1.59 \\
\hline (n) & $\mathrm{TS}_{\mathrm{CH}_{2} \mathrm{CHO}+\mathrm{H}\left(\mathrm{CH}_{3} \mathrm{CHO}\right)}$ & 1.46 \\
\hline (o) & $\mathrm{TS}_{\mathrm{CH}_{3} \mathrm{CO}+\mathrm{H}\left(\mathrm{CH}_{3} \mathrm{CHO}\right)}$ & 1.44 \\
\hline
\end{tabular}




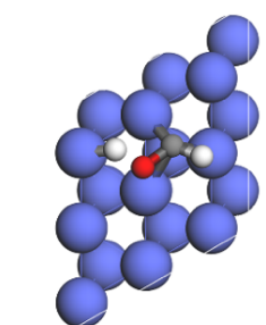

(a)

(b)
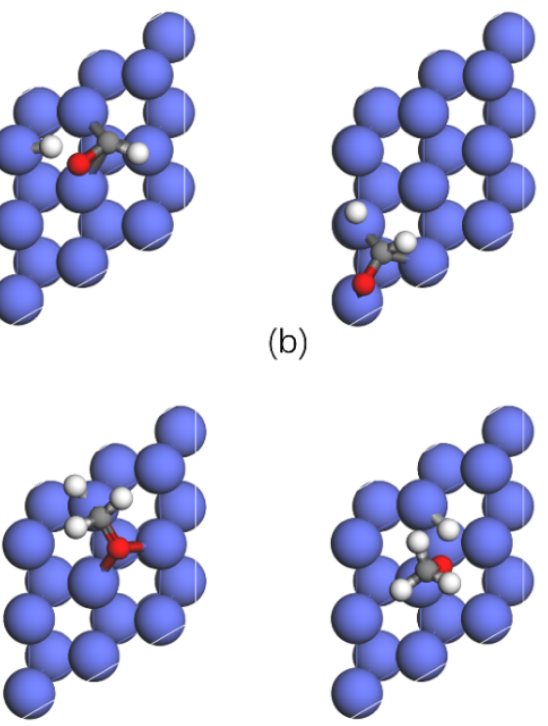

(d)

(g)

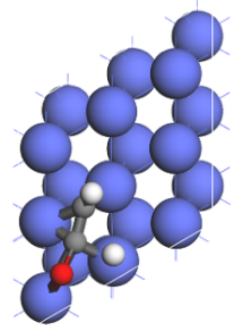

(h)

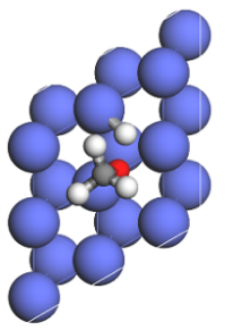

(e)
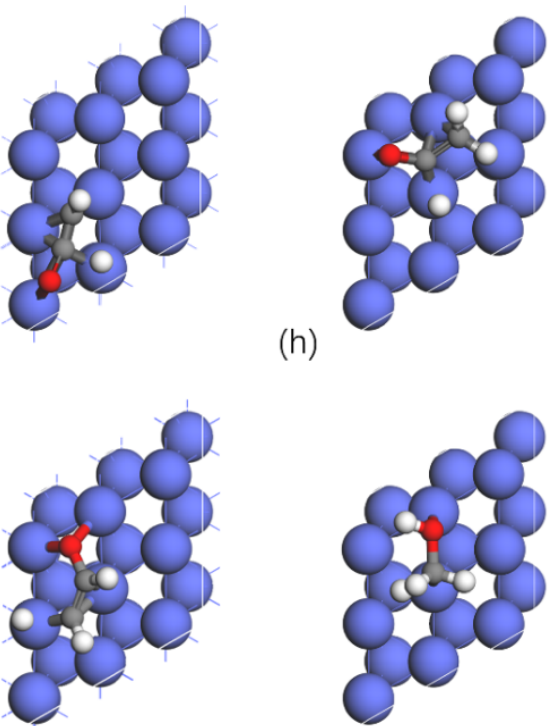

(j)

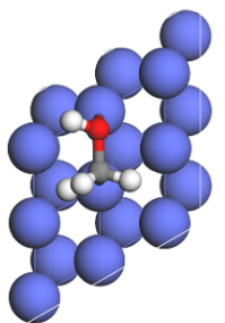

(k)

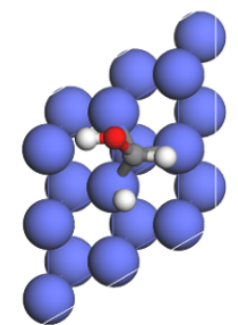

(m)

(n)

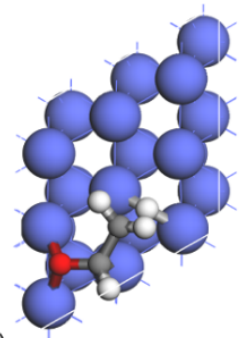

(c)
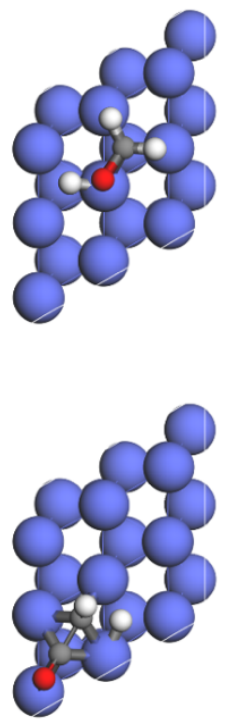

(f)

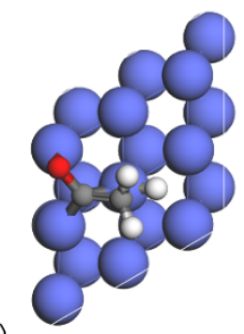

(i)

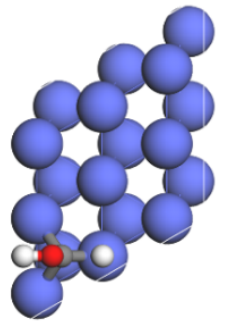

(I)

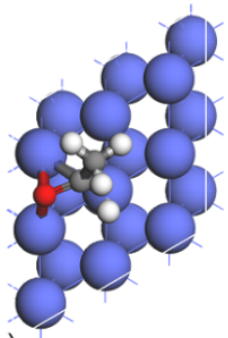

(o)

Figure S15. Top views of the calculated transition state geometries of $\mathrm{C}_{2}$ hydrogenation reactions on $\mathrm{Co}(0001)$. (a) $\mathrm{TS}_{\mathrm{CHO}+\mathrm{H}(\mathrm{CHOH})}$; (b) $\mathrm{TS}_{\mathrm{CHO}+\mathrm{H}\left(\mathrm{CH}_{2} \mathrm{O}\right)}$; (c) $\mathrm{TS}_{\mathrm{CH}_{2} \mathrm{O}+\mathrm{H}\left(\mathrm{CH}_{2} \mathrm{OH}\right)}$; (d) $\mathrm{TS}_{\mathrm{CH}_{2} \mathrm{O}+\mathrm{H}(\mathrm{CH} 3 \mathrm{O})}$; (e) $\mathrm{TS}_{\mathrm{CH}_{3} \mathrm{O}+\mathrm{H}}$ (СH3OH); (f) $\mathrm{TS}_{\mathrm{CHCO}+\mathrm{H}\left(\mathrm{CH}_{2} \mathrm{CO}\right)}$; (g) $\mathrm{TS}_{\mathrm{CHCO}+\mathrm{H}(\mathrm{CHCHO})}$; (h) $\mathrm{TS}_{\mathrm{CH}^{2} \mathrm{CO}+\mathrm{H}\left(\mathrm{CH}_{2} \mathrm{CHO}\right)}$; (i) $\mathrm{TS}_{\mathrm{CH}^{2} \mathrm{CO}+\mathrm{H}\left(\mathrm{CH}_{3} \mathrm{CO}\right)}$; (j) 
$\mathrm{TS}_{\mathrm{CHCHO}+\mathrm{H}(\mathrm{CH} 2 \mathrm{CHO})} ;(\mathrm{k}) \mathrm{TS}_{\mathrm{CH}_{2} \mathrm{OH}+\mathrm{H}(\mathrm{CH} 3 \mathrm{OH})} ;$ (l) $\mathrm{TS}_{\mathrm{COH}+\mathrm{H}(\mathrm{CHOH})} ;(\mathrm{m}) \mathrm{TS}_{\mathrm{CHOH}+\mathrm{H}(\mathrm{CH} 2 \mathrm{OH})} ;(\mathrm{n}) \mathrm{TS}_{\mathrm{CH}_{2} \mathrm{CHO}+\mathrm{H}(\mathrm{CH} 3 \mathrm{CHO})}$;

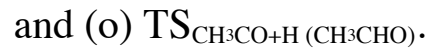

\subsection{0 $\mathrm{CH}_{\mathrm{x}} \mathrm{CH}_{\mathrm{y}} \mathrm{O}$ Dissociation}

$\mathrm{CH}_{\mathrm{x}} \mathrm{CH}_{\mathrm{y}} \mathrm{O}$ dissociations were considered in our simulation. The forward reaction barriers and reaction energies are given in Table $\mathrm{S} 18$. All the $\mathrm{CH}_{\mathrm{x}} \mathrm{CH}_{\mathrm{y}} \mathrm{O}$ dissociations are exothermic. It should be mentioned that $\mathrm{CHCO}^{*}+^{*} \rightleftarrows \mathrm{CCH}^{*} \mathrm{O}^{*}, \mathrm{CH}_{2} \mathrm{CHO}^{*}+^{*} \rightleftarrows \mathrm{CHCH}_{2}{ }^{*} \mathrm{O}^{*}, \mathrm{CH}_{3} \mathrm{CHO}^{*}+*$ $\mathrm{CHCH}_{3}{ }^{*} \mathrm{O}^{*}$ are higher than other $\mathrm{CH}_{\mathrm{x}} \mathrm{CH}_{\mathrm{y}} \mathrm{O}$ dissociation and the corresponding barriers are $1.39 \mathrm{eV}, 1.31 \mathrm{eV}, 1.16 \mathrm{eV}$ and $0.93 \mathrm{eV}$, respectively, and other barriers of $\mathrm{CH}_{\mathrm{x}} \mathrm{CH}_{\mathrm{y}} \mathrm{O}$ dissociation are around $0.8 \mathrm{eV}$. The structures of the transition states are shown in Figure S16 and the corresponding distances of the transition states are listed in Table S19.

Table S18. The forward reaction barriers and reaction energies of $\mathrm{CH}_{x} \mathrm{CH}_{y} \mathrm{O}$ dissociation.

\begin{tabular}{|c|c|c|}
\hline Elementary reaction & $\begin{array}{l}\text { Forward reaction barrier } \\
(\mathrm{eV})\end{array}$ & Reaction energy (eV) \\
\hline $\mathrm{CH}_{2} \mathrm{O}^{*}+* \rightleftarrows \mathrm{CH}_{2}{ }^{*}+\mathrm{O}^{*}$ & 0.83 & -0.82 \\
\hline $\mathrm{CHCO}^{*}+* \rightleftarrows \mathrm{CCH}^{*}+\mathrm{O}^{*}$ & 1.39 & -0.50 \\
\hline $\mathrm{CH}_{2} \mathrm{CO}^{*}+* \rightleftarrows \mathrm{CCH}_{2}^{*}+\mathrm{O}^{*}$ & 0.83 & -0.77 \\
\hline $\mathrm{CH}_{3} \mathrm{CO}^{*}+* \rightleftarrows \mathrm{CCH}_{3}^{*}+\mathrm{O}^{*}$ & 0.83 & -0.81 \\
\hline 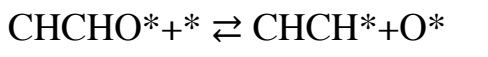 & 0.67 & -1.18 \\
\hline $\mathrm{CH}_{2} \mathrm{CHO}^{*}+* \rightleftarrows \mathrm{CHCH}_{2}^{*}+\mathrm{O}^{*}$ & 1.31 & -0.38 \\
\hline $\mathrm{CH}_{3} \mathrm{O}^{*}+* \underset{\mathrm{CH}_{3} *+\mathrm{O}^{*}}{*}$ & 1.16 & -0.76 \\
\hline $\mathrm{CH}_{3} \mathrm{CHO}^{*}+* \rightleftarrows \mathrm{CHCH}_{3} *+\mathrm{O}^{*}$ & 0.93 & -0.63 \\
\hline
\end{tabular}


(a)

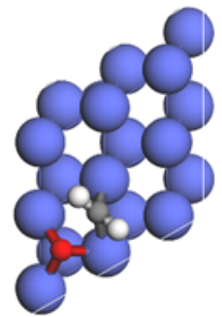

(e)

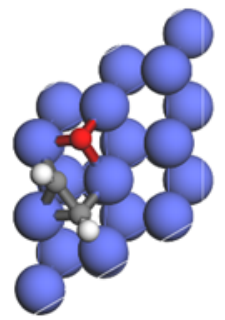

(f)

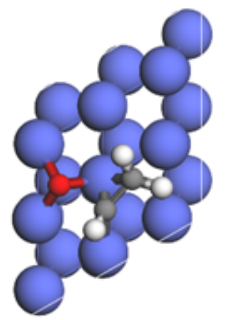

(g)

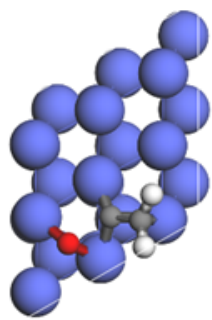

(c)

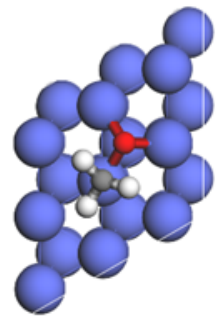

(d)

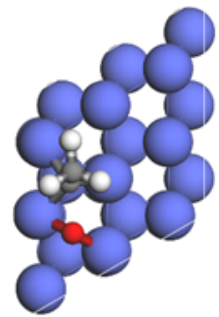

(h)

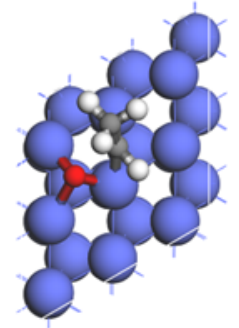

Figure S16. Top views of the calculated transition state geometries of $\mathrm{CH}_{\mathrm{x}} \mathrm{CH}_{\mathrm{y}} \mathrm{O}$ dissociation reactions on $\mathrm{Co}(0001)$. (a) $\mathrm{TS}_{\mathrm{CH}_{2} \mathrm{O}(\mathrm{CH}+\mathrm{O})}$; (b) $\mathrm{TS}_{\mathrm{CHCO}(\mathrm{CHC}+\mathrm{O})}$; (c) $\mathrm{TS}_{\mathrm{CH}_{2} \mathrm{CO}\left(\mathrm{CH}_{2} \mathrm{C}+\mathrm{O}\right)}$; (d) $\mathrm{TS}_{\mathrm{CH}_{3} \mathrm{CO}(\mathrm{CH} 3 \mathrm{C}+\mathrm{O})}$;

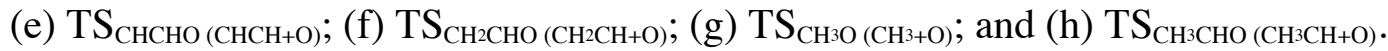

Table S19. Distances at the transition states of $\mathrm{CH}_{x} \mathrm{CH}_{y} \mathrm{O}$ dissociation on $\mathrm{Co}(0001)$.

\begin{tabular}{lll}
\hline & Transition State & Distance $(\AA)$ \\
\hline (a) & $\mathrm{TS}_{\mathrm{CH} 2 \mathrm{O}(\mathrm{CH}+\mathrm{O})}$ & 1.88 \\
(b) & $\mathrm{TS}_{\mathrm{CHCO}(\mathrm{CHC}+\mathrm{O})}$ & 1.79 \\
(c) & $\mathrm{TS}_{\mathrm{CH} 2 \mathrm{CO}(\mathrm{CH} 2 \mathrm{C}+\mathrm{O})}$ & 1.76 \\
(d) & $\mathrm{TS}_{\mathrm{CH} 3 \mathrm{CO}(\mathrm{CH} 3 \mathrm{C}+\mathrm{O})}$ & 1.81 \\
(e) & $\mathrm{TS}_{\mathrm{CHCHO}(\mathrm{CHCH}+\mathrm{O})}$ & 1.76 \\
(f) & $\mathrm{TS}_{\mathrm{CH} 2 \mathrm{CHO}(\mathrm{CH} 2 \mathrm{CH}+\mathrm{O})}$ & 1.85 \\
(g) & $\mathrm{TS}_{\mathrm{CH} 30(\mathrm{CH} 3+\mathrm{O})}$ & 1.88 \\
(h) & $\mathrm{TS}_{\mathrm{CH} 3 \mathrm{CHO}(\mathrm{CH} 3 \mathrm{CH}+\mathrm{O})}$ & 1.84 \\
\hline
\end{tabular}

\section{$1.11 \mathrm{C}_{1}$ and CHO Coupling Reactions}


Formyl was regarded as an important intermediate by in situ spectroscopic experiments for CO methanation on a supported Ru catalyst. ${ }^{17}$ Zhao et al. used DFT calculations to investigate the coupling between $\mathrm{CHO}$ and $\mathrm{CO}$ on $\mathrm{Rh}(111)$ and $\mathrm{Co}(0001)$ and suggested that the $\mathrm{CHO}$ insertion mechanism is competitive with the traditional carbide mechanism. ${ }^{18} \mathrm{We}$ considered the $\mathrm{CHO}$ insertion mechanism in our calculations and the corresponding forward reaction barriers and reaction energies are listed in Table $\mathrm{S} 20$ which are only $0.62 \mathrm{eV}$ and $0.21 \mathrm{eV}$, respectively. All the $\mathrm{C}_{1}$ and $\mathrm{CHO}$ coupling reactions are exothermic. The structures of transition states are shown in Figure S17 and the corresponding distances at the transition states are listed in Table S21.

Table S20. The forward reaction barriers and reaction energies of $\mathrm{C}_{1}$ and $\mathrm{CHO}$ coupling reactions.

\begin{tabular}{lll}
\hline Elementary reaction & Forward barrier $(\mathrm{eV})$ & Reaction energy $(\mathrm{eV})$ \\
\hline $\mathrm{CH}^{*}+\mathrm{CHO}^{*} \rightleftarrows \mathrm{CHCHO}^{*} *$ & 0.62 & -0.25 \\
$\mathrm{CH}_{2}{ }^{*}+\mathrm{CHO}^{*} \rightleftarrows \mathrm{CH}_{2} \mathrm{CHO}^{*}+$ & 0.21 & -0.56 \\
\hline
\end{tabular}

(a)

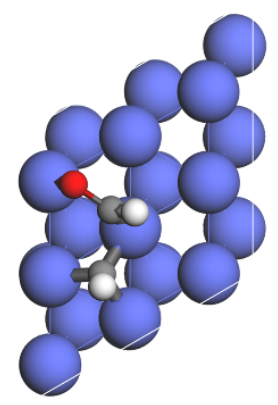

(b)

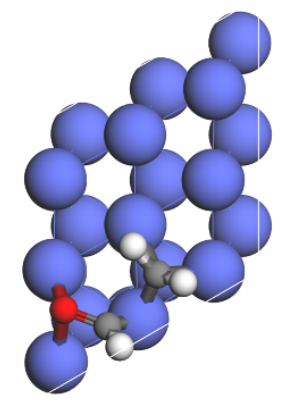

Figure S17. Top views of the calculated transition state geometries of $\mathrm{C}_{1}$ and $\mathrm{CHO}$ coupling

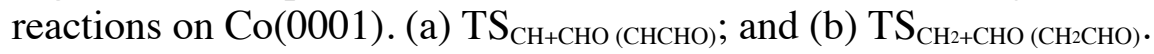

Table S21. Distances at the transition states of $\mathrm{C}_{1}$ and $\mathrm{CHO}$ coupling reactions on $\mathrm{Co}(0001)$.

\begin{tabular}{lll}
\hline & Transition State & Distance $(\AA)$ \\
\hline (a) & $\mathrm{TS}_{\mathrm{CH}+\mathrm{CHO}(\mathrm{CHCHO})}$ & 1.91 \\
(b) & $\mathrm{TS}_{\mathrm{CH}+\mathrm{CHO}(\mathrm{CH} 2 \mathrm{CHO})}$ & 2.04 \\
\hline
\end{tabular}

\subsubsection{Carbide Mechanism}

All the possible coupling reactions in the carbide mechanism on $\mathrm{Co}(0001)$ were calculated with van der Waals's interactions included. Based on the equation of Cheng et al., the reaction rates for $\mathrm{C}_{1}+\mathrm{C}_{1}$ can be expressed as follows: 


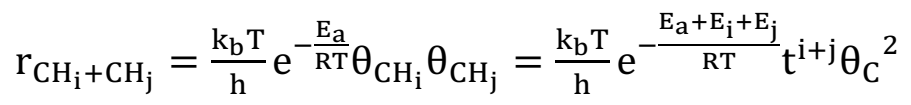

where $\mathrm{r}_{\mathrm{CH}_{\mathrm{i}}+\mathrm{CH}_{\mathrm{j}}}$ is the rate of $\mathrm{C}_{1}+\mathrm{C}_{1}$ coupling; $\mathrm{k}_{\mathrm{b}}$ is the Boltzmann constant, $\mathrm{T}$ is the temperature, $h$ is the Planck constant, $E_{a}$ is the barrier of $C_{1}+C_{1}$ coupling, and $E_{a}+E_{i}+E_{j}$ is defined as the effective barrier. The calculated barriers are listed in Table $\mathrm{S} 8$ and the effective barriers are listed in Table S22. Using the effective barriers in Table S22 and Eq. S1, the $\mathrm{C}_{1}+\mathrm{C}_{1}$ coupling rates were calculated and the results are listed in Table 23. From the reaction rates in Table 23, we can see that the coupling of $\mathrm{CH}+\mathrm{CH}$ is the favored coupling pathway for $\mathrm{C}_{2}$ species with the van der Waals interactions, which is consistent with the results of Cheng et al.. ${ }^{10}$

Table S22. Effective barriers (eV) of all possible $C_{1}$ and $C_{1}$ coupling pathways on $\mathrm{Co}(0001)$.

\begin{tabular}{|c|c|c|c|}
\hline Pathway & $\mathrm{C}+\mathrm{C}$ & $\mathrm{C}+\mathrm{CH}$ & $\mathrm{C}+\mathrm{CH}_{2}$ \\
\hline Effective Barriers & 1.38 & 0.97 & 1.33 \\
\hline Pathway & $\mathrm{C}+\mathrm{CH}_{3}$ & $\mathrm{CH}+\mathrm{CH}$ & $\mathrm{CH}+\mathrm{CH}_{2}$ \\
\hline Effective Barriers & 1.44 & 0.58 & 1.16 \\
\hline Pathway & $\mathrm{CH}+\mathrm{CH}_{3}$ & $\mathrm{CH}_{2}+\mathrm{CH}_{2}$ & $\mathrm{CH}_{2}+\mathrm{CH}_{3}$ \\
\hline Effective Barriers & 1.40 & 1.13 & 1.62 \\
\hline Pathway & $\mathrm{CH}+\mathrm{CO}$ & $\mathrm{CH}_{2}+\mathrm{CO}$ & $\mathrm{CH}_{3}+\mathrm{CO}$ \\
\hline Effective Barriers & 0.90 & 1.00 & 1.73 \\
\hline
\end{tabular}


Table S23. Reaction rates $\left(\mathrm{s}^{-1}\right)$ of all possible $\mathrm{C}_{1}$ and $\mathrm{C}_{1}$ coupling reactions on $\mathrm{Co}(0001)$.

\begin{tabular}{|c|c|c|c|}
\hline Pathway & $\mathrm{C}+\mathrm{C}$ & $\mathrm{C}+\mathrm{CH}$ & $\mathrm{C}+\mathrm{CH}_{2}$ \\
\hline Reaction Rate & $0.12 \theta_{\mathrm{C}}{ }^{2}$ & $1.7 \times 10^{3} \mathrm{t}_{\mathrm{C}}{ }^{2}$ & $0.43 \mathrm{t}^{2} \theta_{\mathrm{C}}{ }^{2}$ \\
\hline Pathway & $\mathrm{C}+\mathrm{CH}_{3}$ & $\mathrm{CH}+\mathrm{CH}$ & $\mathrm{CH}+\mathrm{CH}_{2}$ \\
\hline Reaction Rate & $0.03 \mathrm{t}^{3} \theta_{\mathrm{C}}{ }^{2}$ & $1.3 \times 10^{7} \mathrm{t}^{2} \theta_{\mathrm{C}}{ }^{2}$ & $20 \mathrm{t}^{3} \theta_{\mathrm{C}}{ }^{2}$ \\
\hline Pathway & $\mathrm{CH}+\mathrm{CH}_{3}$ & $\mathrm{CH}_{2}+\mathrm{CH}_{2}$ & $\mathrm{CH}_{2}+\mathrm{CH}_{3}$ \\
\hline Reaction Rate & $0.08 \mathrm{t}^{4} \theta_{\mathrm{C}}{ }^{2}$ & $41 \mathrm{t}^{4} \theta_{\mathrm{C}}{ }^{2}$ & $10^{-4} \mathrm{t}^{5} \theta_{\mathrm{C}}{ }^{2}$ \\
\hline
\end{tabular}

\subsubsection{CO Insertion Mechanism}

According to the transition state theory and Eq. 11, the CO insertion rate can be written as follows:

$r_{\mathrm{CH}_{\mathrm{i}}+\mathrm{CO}}=\frac{\mathrm{k}_{\mathrm{b}} \mathrm{T}}{\mathrm{h}} \mathrm{e}^{\frac{-\mathrm{E}_{\mathrm{a}}}{\mathrm{RT}}} \theta_{\mathrm{CH}_{\mathrm{i}}} \theta_{\mathrm{CO}}=\frac{\mathrm{k}_{\mathrm{b}} \mathrm{T}}{\mathrm{h}} \mathrm{e}^{\frac{-\mathrm{E}_{\mathrm{a}}}{\mathrm{RT}}} \mathrm{e}^{\frac{-\mathrm{E}_{\mathrm{i}}}{\mathrm{RT}}} \theta_{\mathrm{C}} \mathrm{t}^{\mathrm{i}} \theta_{\mathrm{CO}}=\frac{\mathrm{k}_{\mathrm{b}} \mathrm{T}}{\mathrm{h}} \mathrm{e}^{\frac{-\left(\mathrm{E}_{\mathrm{a}}+\mathrm{E}_{\mathrm{i}}\right)}{\mathrm{RT}}} \mathrm{t}^{\mathrm{i}} \theta_{\mathrm{C}} \theta_{\mathrm{CO}}$

where $\mathrm{r}_{\mathrm{CH}_{\mathrm{i}}+\mathrm{CO}}$ is the rate of $\mathrm{CO}$ insertion, $\mathrm{E}_{\mathrm{a}}$ is the barrier of $\mathrm{C} 1+\mathrm{CO}$ coupling, and $\mathrm{E}_{\mathrm{a}}+\mathrm{E}_{\mathrm{i}}$ is the effective barrier. Using the calculated barriers in Table S22, the effective barriers are obtained, which are listed in Table S24. Using the effective barriers in the Table S24 and Eq. S2, the CO insertion rates can be computed and the results are listed in Table S25.

Table S24. Effective barriers $(\mathrm{eV})$ of all the possible $\mathrm{CO}$ insertion reactions on $\mathrm{Co}(0001)$.

\begin{tabular}{|c|c|c|c|}
\hline Pathway & $\mathrm{CH}+\mathrm{CO}$ & $\mathrm{CH}_{2}+\mathrm{CO}$ & $\mathrm{CH}_{3}+\mathrm{CO}$ \\
\hline Effect Barriers & 0.90 & 1.00 & 1.73 \\
\hline
\end{tabular}


Table S25. Reaction rates $\left(\mathrm{s}^{-1}\right)$ of all the possible CO insertion reactions on $\mathrm{Co}(0001)$.

\begin{tabular}{|c|c|c|c|}
\hline Pathway & $\mathrm{CH}+\mathrm{CO}$ & $\mathrm{CH}_{2}+\mathrm{CO}$ & $\mathrm{CH}_{3}+\mathrm{CO}$ \\
\hline Reaction Rate & $7.8 \times 10^{3} \mathrm{t} \theta_{\mathrm{C}} \theta_{\mathrm{CO}}$ & $832 \mathrm{t}^{2} \theta_{\mathrm{C}} \theta_{\mathrm{CO}}$ & $4.0 \times 10^{-5} \mathrm{t}^{3} \theta_{\mathrm{C}} \theta_{\mathrm{CO}}$ \\
\hline
\end{tabular}

From the reaction rates in Table $\mathrm{S} 25$, the coupling of $\mathrm{CH}_{3}+\mathrm{CO}$ is the most difficult one compared with other $\mathrm{CO}$ insertion coupling reactions and the most likely couplings are $\mathrm{CH}+\mathrm{CO}$ and $\mathrm{CH}_{2}+\mathrm{CO}$, from which we can obtain the following equation:

$\frac{\mathrm{r}_{\mathrm{CH}+\mathrm{CO}}}{\mathrm{r}_{\mathrm{CH}_{2}+\mathrm{CO}}}=\frac{7.8 \times 10^{3} \mathrm{t}_{\mathrm{C}} \theta_{\mathrm{CO}}}{832 \mathrm{t}^{2} \theta_{\mathrm{C}} \theta_{\mathrm{CO}}}=\frac{9.375}{\mathrm{t}}$

where the ratio of $\frac{\theta_{\mathrm{H}}}{\theta_{*}}$ is typically about 1 to 10 .

Hence, we can derive

$\mathrm{r}_{\mathrm{CH}+\mathrm{CO}}>\mathrm{r}_{\mathrm{CH}_{2}+\mathrm{CO}}$

$0<t<9.375$

$\mathrm{r}_{\mathrm{CH}+\mathrm{CO}}<\mathrm{r}_{\mathrm{CH}_{2}+\mathrm{CO}}$

$9.375<t<10$

$\mathrm{r}_{\mathrm{CH}+\mathrm{CO}}=\mathrm{r}_{\mathrm{CH}_{2}+\mathrm{CO}}$

$t=9.375$

\subsubsection{CHO Insertion Mechanism}

Similarly, the $\mathrm{CHO}$ insertion rate can be written as:

$\mathrm{r}_{\mathrm{CH}_{\mathrm{i}}+\mathrm{CHO}}=\frac{\mathrm{k}_{\mathrm{b}} \mathrm{T}}{\mathrm{h}} \mathrm{e}^{\frac{-\mathrm{E}_{\mathrm{a}}}{\mathrm{RT}}} \theta_{\mathrm{CH}_{\mathrm{i}}} \theta_{\mathrm{CHO}}=\frac{\mathrm{k}_{\mathrm{b}} \mathrm{T}}{\mathrm{h}} \mathrm{e}^{\frac{-\mathrm{E}_{\mathrm{a}}}{\mathrm{RT}}} \mathrm{e}^{\frac{-\mathrm{E}_{\mathrm{i}}}{\mathrm{RT}}} \theta_{\mathrm{C}} \mathrm{t}^{\mathrm{i}} \theta_{\mathrm{CHO}}=\frac{\mathrm{k}_{\mathrm{b}} \mathrm{T}}{\mathrm{h}} \mathrm{e}^{\frac{-\left(\mathrm{E}_{\mathrm{a}}+\mathrm{E}_{\mathrm{i}}\right)}{\mathrm{RT}}} \mathrm{t}^{\mathrm{i}} \theta_{\mathrm{C}} \theta_{\mathrm{CHO}}$

where $\mathrm{r}_{\mathrm{CH}_{\mathrm{i}}+\mathrm{CHO}}$ is the rate of $\mathrm{CHO}$ insertion, $\mathrm{E}_{\mathrm{a}}$ is the barrier of $\mathrm{C}_{1}+\mathrm{CHO}$ coupling, and $\mathrm{E}_{\mathrm{a}}+\mathrm{E}_{\mathrm{i}}$ is the effective barrier. Based on the calculated barriers in Table S20, the effective barriers are determined and listed in Table S26. Using the effective barriers in Table S26 and Eq. S7, the CHO 
insertion rates are obtained (Table S27), which show that the couplings of $\mathrm{CH}_{2}+\mathrm{CHO}$ and $\mathrm{CH}+\mathrm{CHO}$ are similar with $\mathrm{CH}+\mathrm{CHO}$ being slightly favored.

Table S26. Effective barriers $(\mathrm{eV})$ of all the possible $\mathrm{CHO}$ insertion reactions on $\mathrm{Co}(0001)$.

\begin{tabular}{|c|c|c|}
\hline Pathway & $\mathrm{CH}+\mathrm{CHO}$ & $\mathrm{CH}_{2}+\mathrm{CHO}$ \\
\hline Effect Barriers & 0.56 & 0.52 \\
\hline
\end{tabular}

Table S27. Reaction rates $\left(\mathrm{s}^{-1}\right)$ of all the possible $\mathrm{CHO}$ insertion reactions on $\mathrm{Co}(0001)$.

\begin{tabular}{|c|c|c|}
\hline Pathway & $\mathrm{CH}+\mathrm{CHO}$ & $\mathrm{CH}_{2}+\mathrm{CHO}$ \\
\hline Reaction Rate & $2.3 \times 10^{7} \mathrm{t} \theta_{\mathrm{C}} \theta_{\mathrm{CHO}}$ & $5.7 \times 10^{7} \mathrm{t}^{2} \theta_{\mathrm{C}} \theta_{\mathrm{CHO}}$ \\
\hline
\end{tabular}

\subsection{Choice of Partial Pressure and Temperature}

The kinetic simulations were carried out at pressure at 10 bars, and the ratio of $\mathrm{H}_{2}$ to $\mathrm{CO}$ is 2 . The partial pressures were estimated from experimental data. ${ }^{19-20}$

Table S28. Partial pressures of gases on Co(0001) at $500 \mathrm{~K}$. All the values are in bar.

\begin{tabular}{|l|l|l|l|l|l|l|}
\hline \multicolumn{7}{|c|}{ Partial pressure on Cobalt Surface (bar) at $500 \mathrm{~K}$} \\
\hline $\mathrm{CO}$ & $\mathrm{H}_{2}$ & $\mathrm{CH}_{4}$ & $\mathrm{H}_{2} \mathrm{O}$ & $\mathrm{C}_{2} \mathrm{H}_{4}$ & $\mathrm{C}_{2} \mathrm{H}_{6}$ & $\mathrm{CH}_{3} \mathrm{OH}$ \\
\hline 3.33 & 6.67 & 0.457 & 0.01 & 0.0087 & 0.0261 & 0.01 \\
\hline
\end{tabular}

\subsection{Differential Chemisorption Energies}

Based on strong $\mathrm{CO}$ adsorption on the cobalt surface, it is expected that $\mathrm{CO}$ will be the most abundant surface intermediate, and thus our model includes all interactions of surface intermediates with $\mathrm{CO}$. 
The differential chemisorption energy is used in our kinetic modeling and is calculated as follows:

$E_{\text {differential }}\left(\frac{1}{2}\left(\frac{n-1}{N}+\frac{n}{N}\right)\right)=E_{n \cdot a d s o r b a t e}-E_{(n-1) \cdot a d s o r b a t e}-E_{\text {gas }}$

where $\mathrm{n}$ is the number of the adsorbate, $\mathrm{N}$ is the number of surface sites in the unit cell, $\mathrm{E}_{\text {differential }}\left(\frac{1}{2}\left(\frac{\mathrm{n}-1}{\mathrm{~N}}+\frac{\mathrm{n}}{\mathrm{N}}\right)\right)$ represents the differential chemisorption energy at the middle point coverage at $\left(\frac{n-1}{N}+\frac{n}{N}\right), E_{n}$.adsorbate represents the total energy of metal with $n$ adsorbates, $E_{(n-1) . a d s o r b a t e}$ represents the total energy of metal with $n-1$ adsorbates and $E_{\text {gas }}$ is the total energy of the adsorbate in the gas phase.

The threshold coverage is usually located at $0.33 \mathrm{ML}$ on $\mathrm{Co}(0001)$, and this point is also consistent with experimental work. ${ }^{21}$ If the coverage of $\mathrm{CO}$ is in the low coverage region, the differential chemisorption of $\mathrm{CO}$ can be regarded as a constant. However, if the coverage of $\mathrm{CO}$ is located in the high coverage region, $\mathrm{CO}-\mathrm{CO}$ interactions will weaken the differential chemisorption energy. 

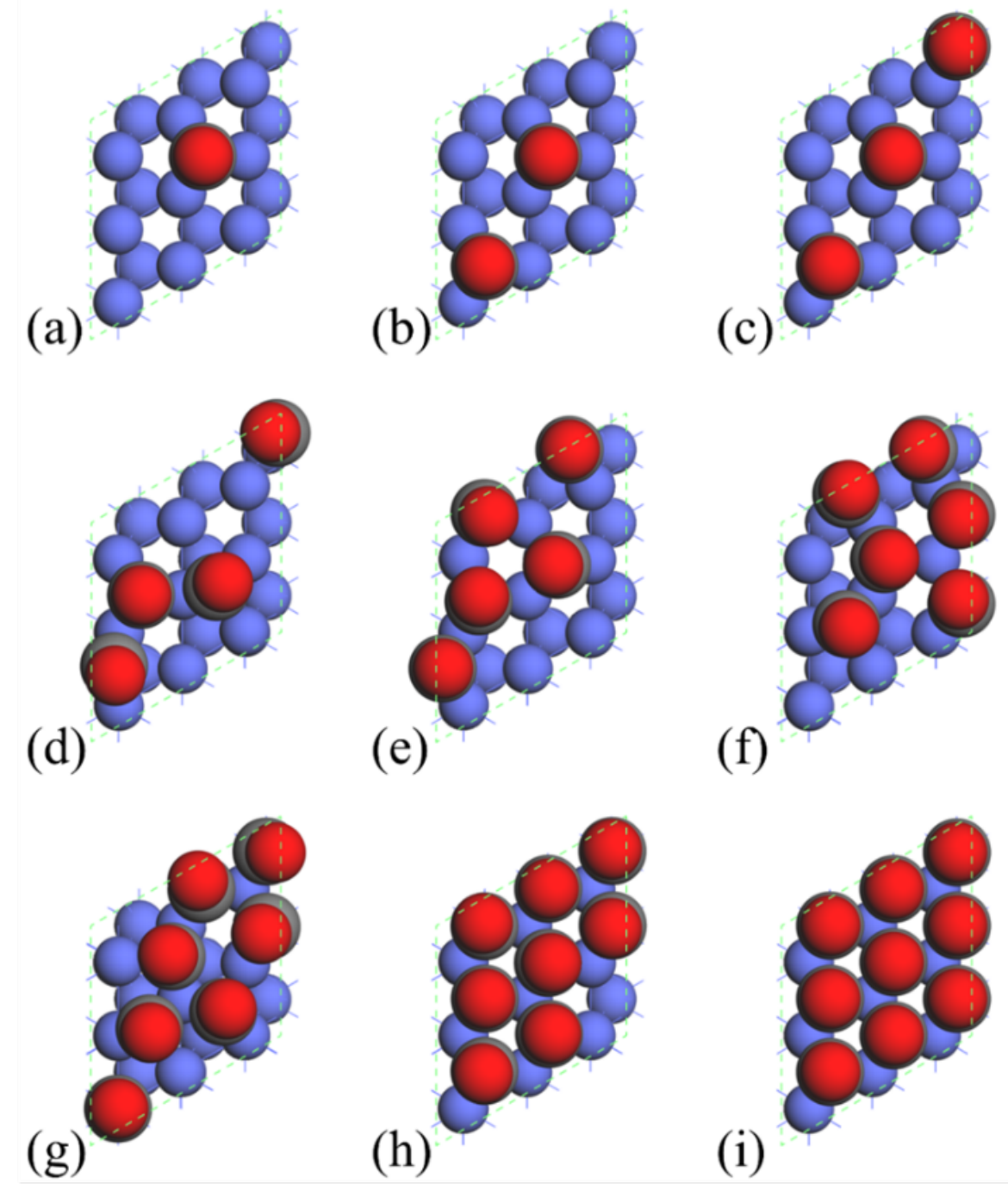

Figure S18. The calculated structures of $\mathrm{CO}$ adsorption with varying amounts of coverage on $\mathrm{Co}(0001)$ in the $\mathrm{p}(3 \times 3)$ unit cell. The red, grey and blue balls represent $\mathrm{O}, \mathrm{C}, \mathrm{Co}$ atoms, respectively. (a) 1/9 ML; (b) 2/9 ML; (c) 3/9 ML; (d) 4/9 ML; (e) 5/9 ML; (f) 6/9 ML; (g) 7/9 ML; (h) $8 / 9 \mathrm{ML}$; and (i) $1 \mathrm{ML}$.

\subsection{High CO Coverage Intermediates and Transition States}

The key issue of the coverage dependent kinetic model is to find the most stable geometry at a particular coverage. For the transition states, we firstly obtained the structure at a low coverage and then the transition state was fixed and the lowest energy configuration at a certain CO coverage was searched. Finally, we located the final geometry of the transition state using constrained optimization scheme. ${ }^{22-24}$ 


\subsubsection{Intermediates under CO Environment}

\subsubsection{4CO+intermediates}

(a)

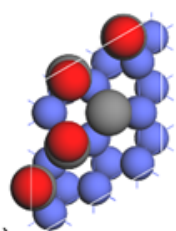

(b)

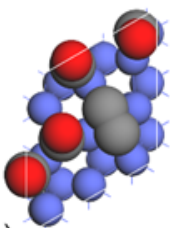

(c)

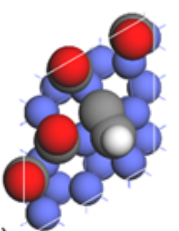

(d)

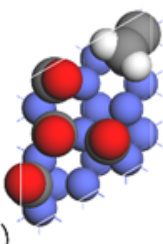

(e)

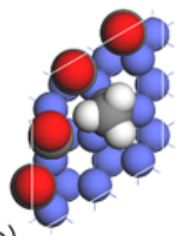

(f)

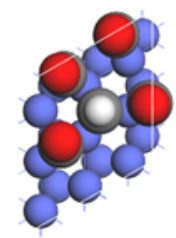

(k)

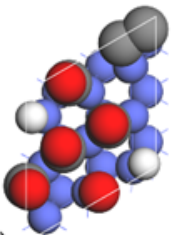

(i)

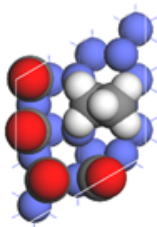

(j)

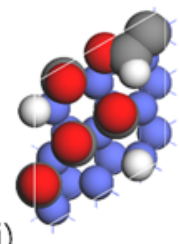

(h)

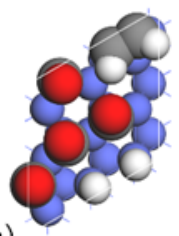

(g)

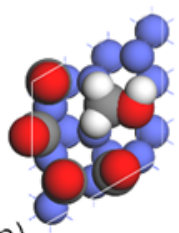

(m)
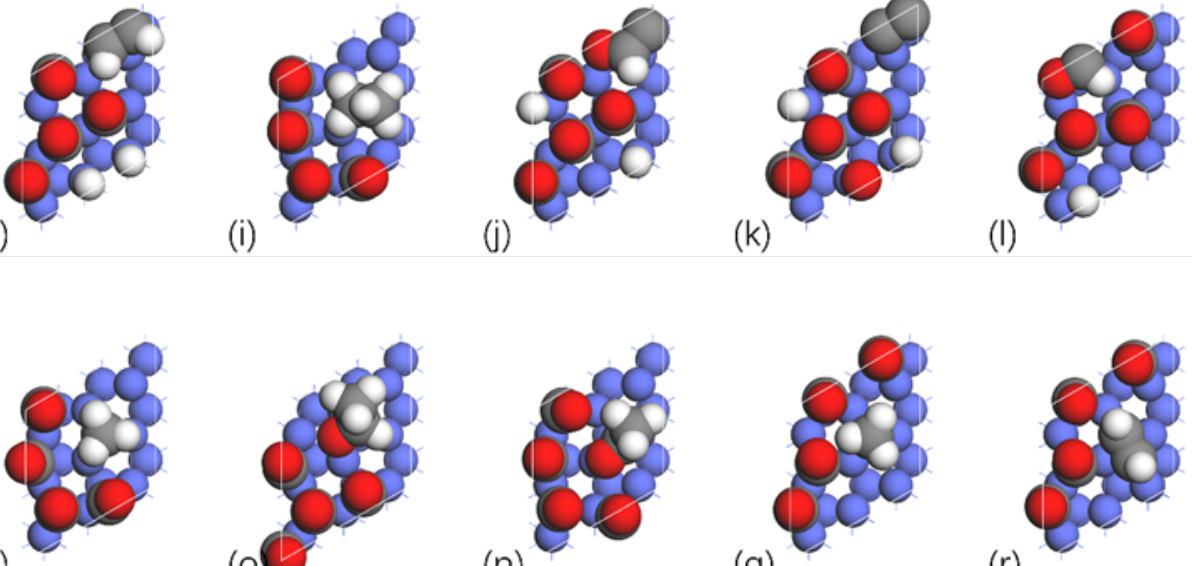

(I) (n)

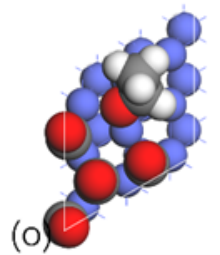

(p)

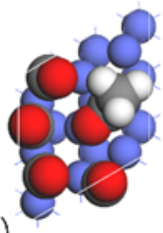

(q)

(r)

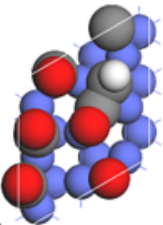

(v)

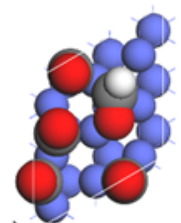

(w)

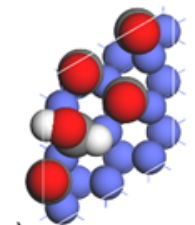

$(\mathrm{x})$
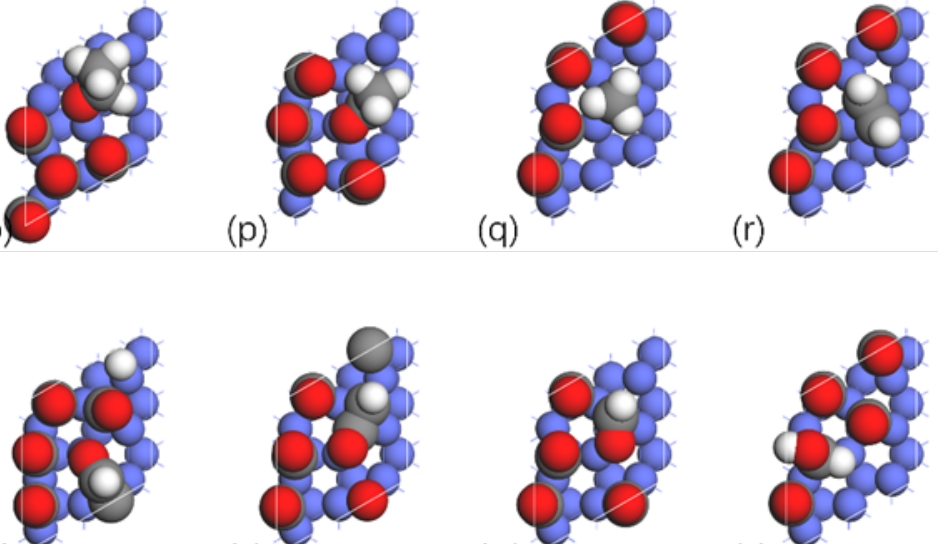

(u)

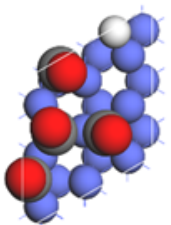

(z)
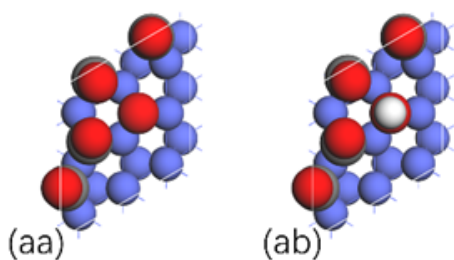

Figure S19. Top views of all the optimized geometries of intermediates in the presence of $4 \mathrm{CO}$ on $\mathrm{Co}(0001)$. (a) $\mathrm{C}$; (b) $\mathrm{CC}$; (c) $\mathrm{CCH}$; (d) $\mathrm{CCH}_{2}$; (e) $\mathrm{CCH}_{3}$; (f) $\mathrm{CH}$; (g) $\mathrm{CH}_{2}$; (h) $\mathrm{CH}_{2} \mathrm{CH}_{2}$; (i) $\mathrm{CH}_{3} \mathrm{CH}_{2}$; (j) $\mathrm{CH}_{2} \mathrm{CHO}$; (k) $\mathrm{CH}_{2} \mathrm{CO}$; (1) $\mathrm{CH}_{2} \mathrm{O}$; (m) $\mathrm{CH}_{2} \mathrm{OH}$; (n) $\mathrm{CH}_{3}$; (o) $\mathrm{CH}_{3} \mathrm{CHO}$; (p) $\mathrm{CH}_{3} \mathrm{CO}$; (q) $\mathrm{CH}_{3} \mathrm{O}$; (r) $\mathrm{CHCH}$; (s) $\mathrm{CHCH}_{2}$; (t) $\mathrm{CHCH}_{3}$; (u) $\mathrm{CHCHO}$; (v) $\mathrm{CHCO}$; (w) $\mathrm{CHO}$; (x) $\mathrm{CHOH}$; (y) $\mathrm{COH}$; (z) $\mathrm{H}$; (aa) $\mathrm{O}$; and (ab) $\mathrm{OH}$. 


\subsubsection{5CO+intermediates}

(a)

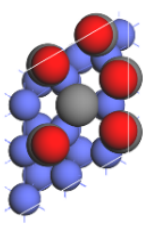

(b)

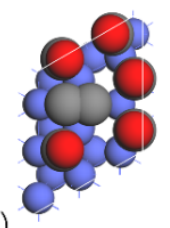

(c)

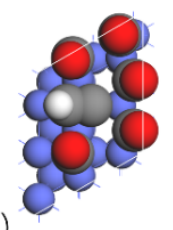

(d)

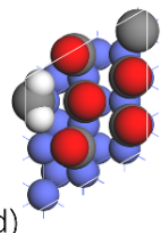

(e)

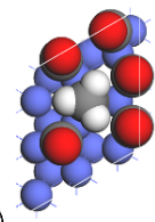

(f)

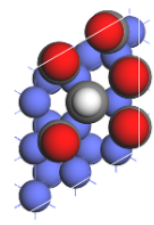

(j)

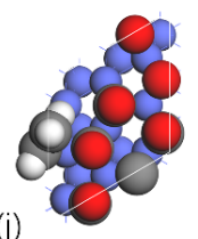

(k)

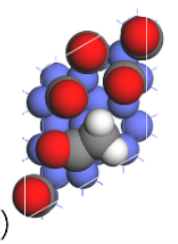

(l)

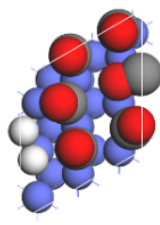

(r)

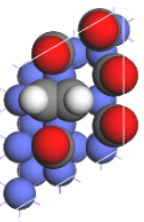

(o)

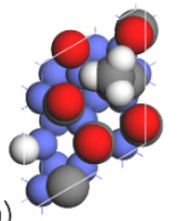

(p)

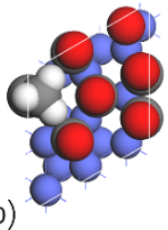

(q)
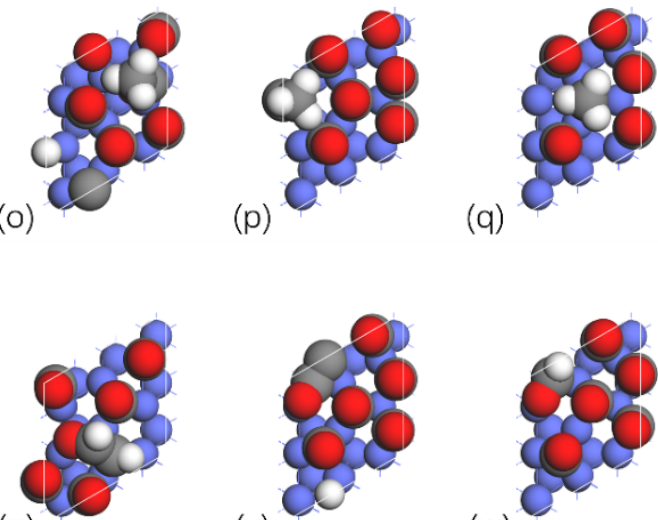

(u)

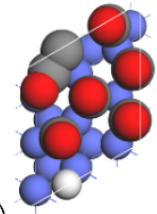

(v)

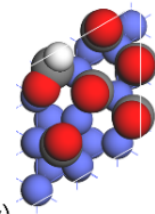

(w)

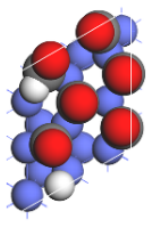

(x)

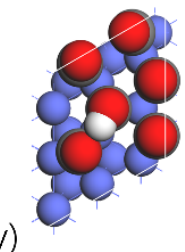

(z)

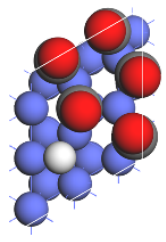

(aa)

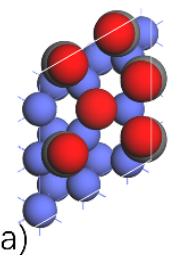

(ab)

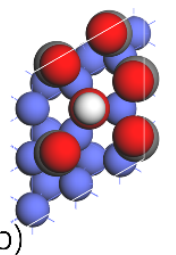

Figure S20. Top views of all the optimized geometries of intermediates in the presence of 5CO on $\mathrm{Co}\left(0001\right.$ ). (a) $\mathrm{C}$; (b) $\mathrm{CC}$; (c) $\mathrm{CCH}$; (d) $\mathrm{CCH}_{2}$; (e) $\mathrm{CCH}_{3}$; (f) $\mathrm{CH}$; (g) $\mathrm{CH}_{2}$; (h) $\mathrm{CH}_{2} \mathrm{CH}_{2}$; (i) $\mathrm{CH}_{3} \mathrm{CH}_{2}$; (j) $\mathrm{CH}_{2} \mathrm{CHO}$; (k) $\mathrm{CH}_{2} \mathrm{CO}$; (l) $\mathrm{CH}_{2} \mathrm{O}$; (m) $\mathrm{CH}_{2} \mathrm{OH}$; (n) $\mathrm{CH}_{3}$; (o) $\mathrm{CH}_{3} \mathrm{CHO}$; (p) $\mathrm{CH}_{3} \mathrm{CO}$; (q) $\mathrm{CH}_{3} \mathrm{O}$; (r) $\mathrm{CHCH}$; (s) $\mathrm{CHCH}_{2}$; (t) $\mathrm{CHCH}_{3}$; (u) $\mathrm{CHCHO}$; (v) $\mathrm{CHCO}$; (w) $\mathrm{CHO}$; (x) $\mathrm{CHOH}$; (y) $\mathrm{COH}$; (z) H; (aa) O; and (ab) $\mathrm{OH}$. 
(a)

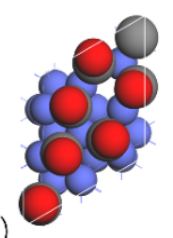

(g)

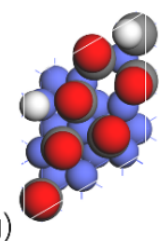

(h)
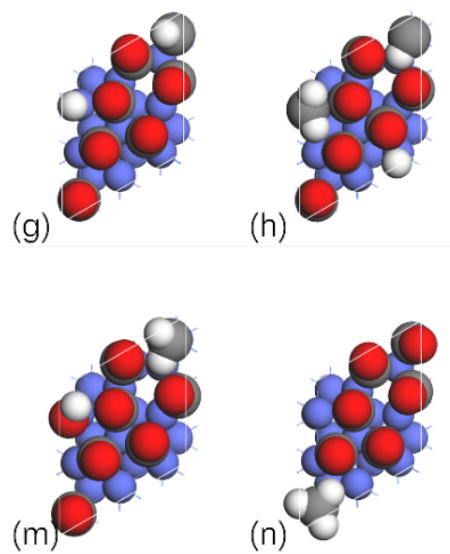

(s)

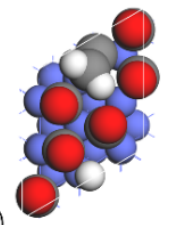

(n)

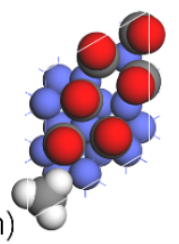

(o)

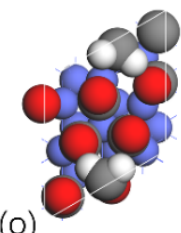

(p)

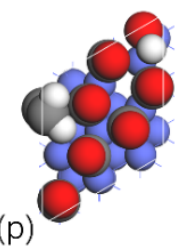

(q)

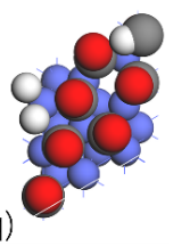

( $\mathrm{r})$

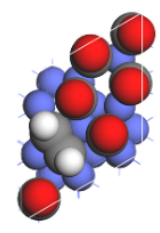

(v)

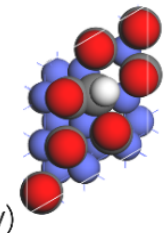

(f)

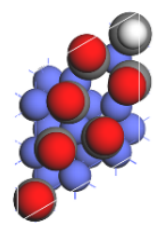

(l)

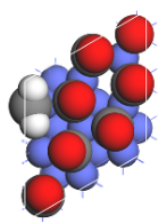

(k)
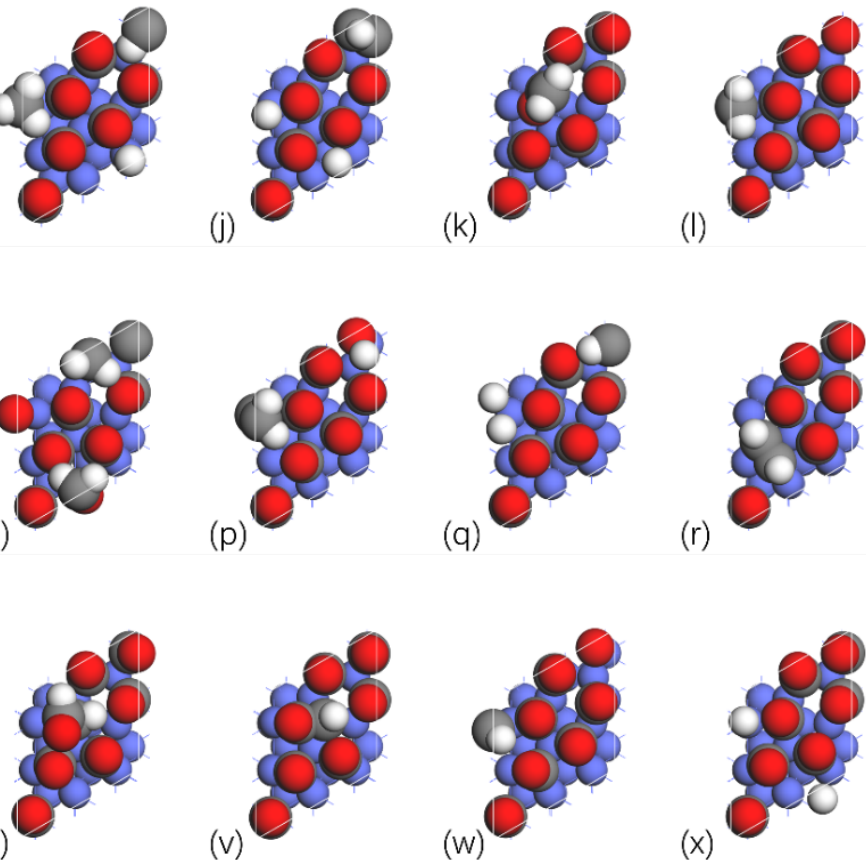

(x)

(z)
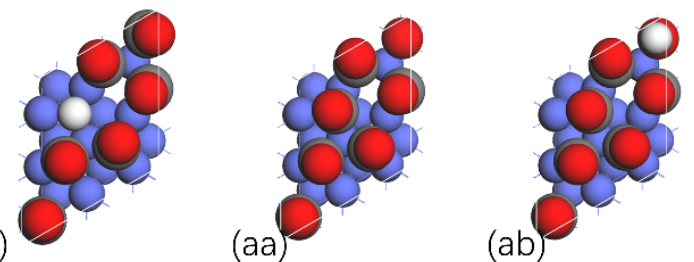

Figure S21. Top views of all the optimized geometries of intermediates in the presence of $6 \mathrm{CO}$ on $\mathrm{Co}\left(0001\right.$ ). (a) $\mathrm{C}$; (b) $\mathrm{CC}$; (c) $\mathrm{CCH}$; (d) $\mathrm{CCH}_{2}$; (e) $\mathrm{CCH}_{3}$; (f) $\mathrm{CH}$; (g) $\mathrm{CH}_{2}$; (h) $\mathrm{CH}_{2} \mathrm{CH}_{2}$; (i) $\mathrm{CH}_{3} \mathrm{CH}_{2}$; (j) $\mathrm{CH}_{2} \mathrm{CHO}$; (k) $\mathrm{CH}_{2} \mathrm{CO}$; (l) $\mathrm{CH}_{2} \mathrm{O}$; (m) $\mathrm{CH}_{2} \mathrm{OH}$; (n) $\mathrm{CH}_{3}$; (o) $\mathrm{CH}_{3} \mathrm{CHO}$; (p) $\mathrm{CH}_{3} \mathrm{CO}$; (q) $\mathrm{CH}_{3} \mathrm{O}$; (r) $\mathrm{CHCH}$; (s) $\mathrm{CHCH}_{2}$; (t) $\mathrm{CHCH}_{3}$; (u) $\mathrm{CHCHO}$; (v) $\mathrm{CHCO}$; (w) $\mathrm{CHO}$; (x) $\mathrm{CHOH}$; (y) $\mathrm{COH}$; (z) $\mathrm{H}$; (aa) $\mathrm{O}$; and (ab) $\mathrm{OH}$. 


\subsubsection{Transition States under CO Environment}

\subsubsection{The transition states in the presence of $4 \mathrm{CO}$}

\subsection{Direct $\mathrm{CO}$ dissociation and $\mathrm{H}$-assisted $\mathrm{CO}$ dissociation with $4 \mathrm{CO}$}

(a)

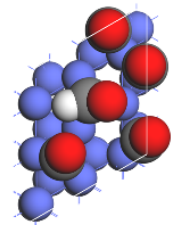

(b)

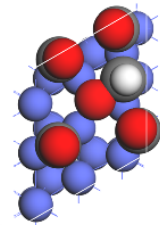

(c)

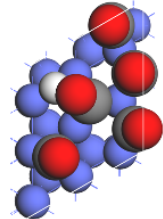

(d)

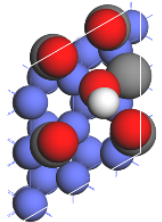

(e)

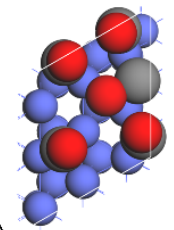

Figure S22. Top views of the calculated transition state geometries of direct $\mathrm{CO}$ dissociation and $\mathrm{H}$-assisted $\mathrm{CO}$ dissociation reactions on $\mathrm{Co}(0001)$ in the presence of $4 \mathrm{CO}$. (a) $\mathrm{TS}_{\mathrm{CO}+\mathrm{H}(\mathrm{CHO})}$; (b) $\mathrm{TS}_{\mathrm{CHO}(\mathrm{CH}+\mathrm{O})}$; (c) $\mathrm{TS}_{\mathrm{CO}+\mathrm{H}(\mathrm{COH})}$; (d) $\mathrm{TS}_{\mathrm{COH}(\mathrm{C}+\mathrm{OH})}$; and (e) $\mathrm{TS}_{\mathrm{CO}(\mathrm{C}+\mathrm{O})}$.

\subsection{Water formation in the presence of $4 \mathrm{CO}$}

(a)

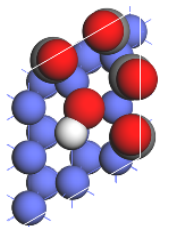

(b)

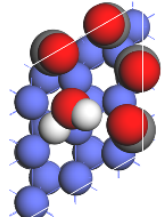

(c)

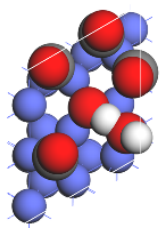

Figure S23. Top views of the calculated transition state geometries of water formation on $\mathrm{Co}(0001)$ in the presence of $4 \mathrm{CO}$. (a) $\mathrm{TS}_{\mathrm{O}+\mathrm{H}(\mathrm{OH})}$; (b) $\mathrm{TS}_{\mathrm{H}+\mathrm{OH}\left(\mathrm{H}_{2} \mathrm{O}\right)}$; and (c) $\mathrm{TS}_{\mathrm{OH}+\mathrm{OH}\left(\mathrm{H}_{2} \mathrm{O}+\mathrm{O}\right)}$.

\subsubsection{3 $\mathrm{C}_{1}$ hydrogenation to methane in the presence of $4 \mathrm{CO}$}

(a)

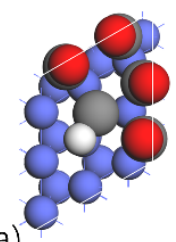

(b)

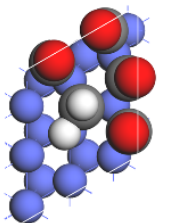

(c)

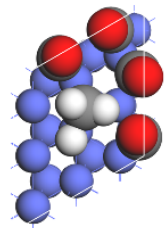

(d)

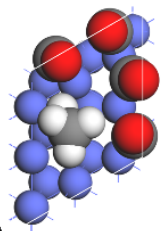

Figure S24. Top views of the calculated transition state geometries of $\mathrm{C}_{1}$ hydrogenation to methane on $\mathrm{Co}(0001)$ in the presence of $4 \mathrm{CO}$. (a) $\mathrm{TS}_{\mathrm{C}+\mathrm{H}(\mathrm{CH})}$; (b) $\mathrm{TS}_{\mathrm{CH}+\mathrm{H}\left(\mathrm{CH}_{2}\right)}$; (c) $\mathrm{TS}_{\mathrm{CH} 2+\mathrm{H}(\mathrm{CH} 3)}$; and (d) $\mathrm{TS}_{\mathrm{CH} 3+\mathrm{H}(\mathrm{CH} 4)}$. 


\subsubsection{4 $\mathrm{C}_{1}+\mathrm{C}_{1}$ coupling reactions in the presence of $4 \mathrm{CO}$}

(a)

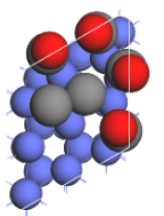

(b)

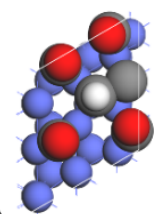

(c)

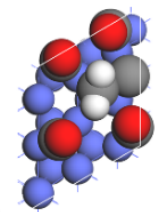

(d)

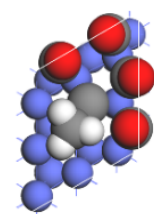

(e)

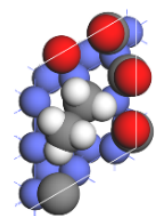

(f)

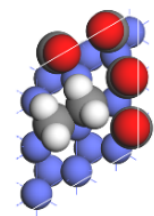

(g)

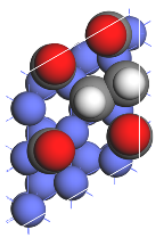

(h)

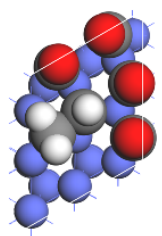

(i)

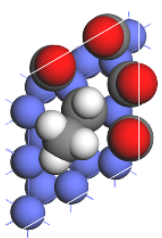

Figure S25. Top views of the calculated transition state geometries of $\mathrm{C}_{1}+\mathrm{C}_{1}$ coupling reactions on $\mathrm{Co}\left(0001\right.$ ) in the presence of $4 \mathrm{CO}$. (a) $\mathrm{TS}_{\mathrm{C}+\mathrm{C}}$; (b) $\mathrm{TS}_{\mathrm{C}+\mathrm{CH}}$; (c) $\mathrm{TS}_{\mathrm{C}+\mathrm{CH} 2}$; (d) $\mathrm{TS}_{\mathrm{C}+\mathrm{CH} 3}$; (e) $\mathrm{TS}_{\mathrm{CH}^{2}+\mathrm{CH}_{3}}$; (f) $\mathrm{TS}_{\mathrm{CH} 2+\mathrm{CH} 2}$; (g) $\mathrm{TS}_{\mathrm{CH}+\mathrm{CH}}$; (h) $\mathrm{TS}_{\mathrm{CH}+\mathrm{CH} 2}$; and (i) $\mathrm{TS}_{\mathrm{CH}+\mathrm{CH}_{3}}$.

\subsubsection{5 $\mathrm{C}_{2}$ hydrogenation reactions in the presence of $4 \mathrm{CO}$}

(a)

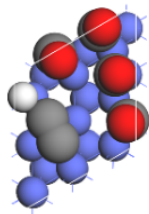

(g)

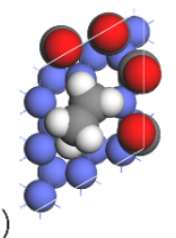

(b)

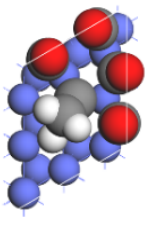

(h)

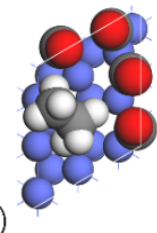

(c)

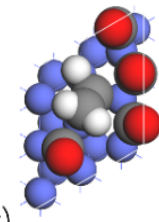

(i)

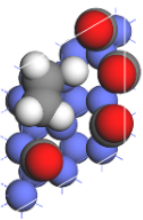

(d)

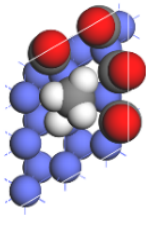

(e)

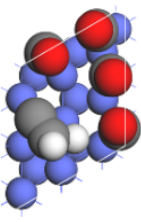

(j)

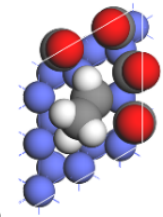

(k)

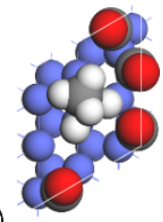

(f)

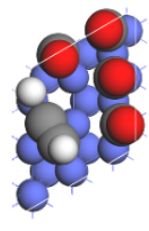

(l)

Figure S26. Top views of the calculated transition state geometries of $\mathrm{C}_{2}$ hydrogenations on $\mathrm{Co}(0001)$ in the presence of $4 \mathrm{CO}$. (a) $\mathrm{TS}_{\mathrm{CC}+\mathrm{H}(\mathrm{CCH})}$; (b) $\mathrm{TS}_{\mathrm{CCH} 2+\mathrm{H}\left(\mathrm{CCH}_{3}\right)}$; (c) $\mathrm{TS}_{\mathrm{CCH}^{2}+\mathrm{H}\left(\mathrm{CHCH}_{2}\right)}$; (d) $\mathrm{TS}_{\mathrm{CCH}^{3}+\mathrm{H}}$ ( $\left.\mathrm{CHCH}_{3}\right)$; (e) $\mathrm{TS}_{\mathrm{CCH}+\mathrm{H}\left(\mathrm{CCH}_{2}\right)}$; (f) $\mathrm{TS}_{\mathrm{CCH}+\mathrm{H}(\mathrm{CHCH})}$; (g) $\mathrm{TS}_{\mathrm{CH}_{2} \mathrm{CH}_{2}+\mathrm{H}\left(\mathrm{CH}_{2} \mathrm{CH}_{3}\right)}$; (h) $\mathrm{TS}_{\mathrm{CH}_{2} \mathrm{CH}_{3}+\mathrm{H}\left(\mathrm{CH}_{3} \mathrm{CH}_{3}\right)}$; (i) $\mathrm{TS}_{\mathrm{CHCH}^{2}+\mathrm{H}}$ $\left(\mathrm{CH}_{2} \mathrm{CH}_{2}\right) ;(\mathrm{j}) \mathrm{TS}_{\mathrm{CHCH} 2+\mathrm{H}(\mathrm{CHCH} 3)}$; (k) $\mathrm{TS}_{\mathrm{CHCH}_{3}+\mathrm{H}\left(\mathrm{CH}_{2} \mathrm{CH} 3\right)}$; (l) $\mathrm{TS}_{\mathrm{CHCH}+\mathrm{H}\left(\mathrm{CHCH}_{2}\right)}$. 


\subsubsection{6 $\mathrm{CO}$ and $\mathrm{C}_{1}$ coupling reactions in the presence of $4 \mathrm{CO}$}

(a)

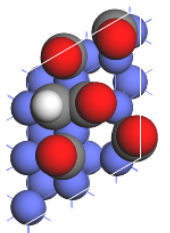

(b)

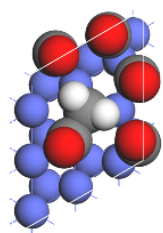

(c)

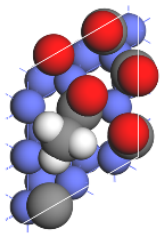

Figure S27. Top views of the calculated transition state geometries of $\mathrm{CO}$ and $\mathrm{C}_{1}$ coupling reactions in the presence of $4 \mathrm{CO}$ on $\mathrm{Co}(0001)$. (a) $\mathrm{TS}_{\mathrm{CH}+\mathrm{CO}(\mathrm{CHCO})}$; (b) $\mathrm{TS}_{\mathrm{CH}^{2}+\mathrm{CO}\left(\mathrm{CH}_{2} \mathrm{CO}\right)}$; and (c)

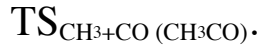

\subsubsection{7 $\mathrm{C}_{1}$ and $\mathrm{OH}$ coupling reactions in the presence of $4 \mathrm{CO}$}

(a)

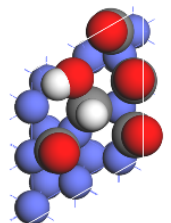

(b)

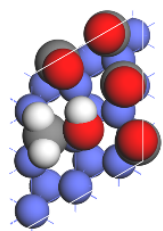

(c)

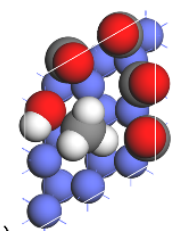

Figure S28. Top views of the calculated transition state geometries of $\mathrm{C}_{1}$ and $\mathrm{OH}$ coupling reactions in the presence of $4 \mathrm{CO}$ on $\mathrm{Co}(0001)$. (a) $\mathrm{TS}_{\mathrm{CH}+\mathrm{OH}(\mathrm{CHOH})}$; (b) $\mathrm{TS}_{\mathrm{CH}^{2}+\mathrm{OH}(\mathrm{CH} 2 \mathrm{OH})}$; and (c) $\mathrm{TS}_{\mathrm{CH} 3+\mathrm{OH}(\mathrm{CH} 3 \mathrm{OH})}$. 


\subsubsection{8 $\mathrm{CH}_{x} \mathrm{CH}_{y} \mathrm{O}$ hydrogenations in the presence of $4 \mathrm{CO}$}

(a)

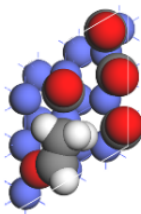

(b)

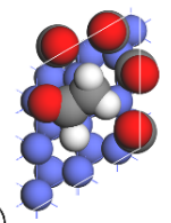

(c)

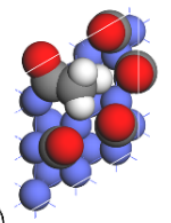

(d)
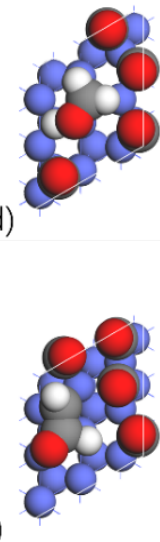

(g)

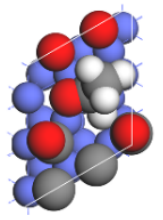

(h)
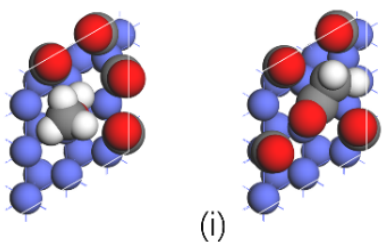

(j) (e)

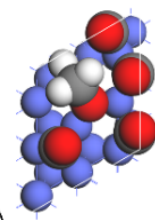

(f)

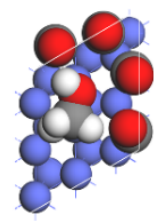

(k)

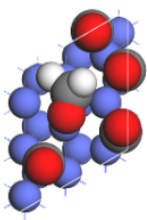

(I)

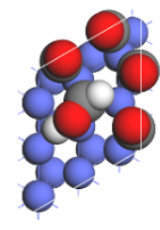

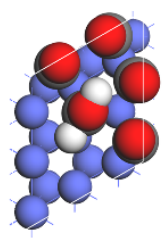

(m)

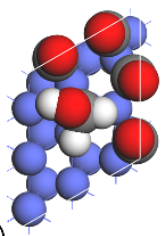

(n)

Figure S29. Top views of the calculated transition state geometries of $\mathrm{CH}_{\mathrm{x}} \mathrm{CH}_{\mathrm{y}} \mathrm{O}$ hydrogenations

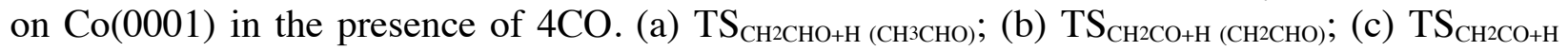
(CH3CO); (d) $\mathrm{TS}_{\mathrm{CH} 2 \mathrm{O}+\mathrm{H}(\mathrm{CH} 2 \mathrm{OH})}$; (e) $\mathrm{TS}_{\mathrm{CH} 2 \mathrm{O}+\mathrm{H}(\mathrm{CH} 3 \mathrm{O})}$; (f) $\mathrm{TS}_{\mathrm{CH} 2 \mathrm{OH}+\mathrm{H}(\mathrm{CH} 3 \mathrm{OH})}$; (g) $\mathrm{TS}_{\mathrm{CH} 3 \mathrm{CO}+\mathrm{H}(\mathrm{CH} 3 \mathrm{CHO})}$; (h) $\mathrm{TS}_{\mathrm{CH} 3 \mathrm{O}+\mathrm{H}}$ (СH3OH); (i) $\mathrm{TS}_{\mathrm{CHCO}+\mathrm{H}(\mathrm{CH} 2 \mathrm{CO})}$; (j) $\mathrm{TS}_{\mathrm{CHCO}+\mathrm{H}(\mathrm{CHCHO})}$; (k) $\mathrm{TS}_{\mathrm{CHO}+\mathrm{H}(\mathrm{CH} 2 \mathrm{O})}$; (l) $\mathrm{TS}_{\mathrm{CHO}+\mathrm{H}(\mathrm{CHOH})}$; (m) $\mathrm{TS}_{\mathrm{CHOH}+\mathrm{H}}$ (СH2OH); and (n) $\mathrm{TS}_{\mathrm{COH}+\mathrm{H}(\mathrm{CHOH})}$.

\subsubsection{9 $\mathrm{CH}_{x} \mathrm{CH}_{y} \mathrm{O}$ dissociation in the presence of $4 \mathrm{CO}$}

(a)

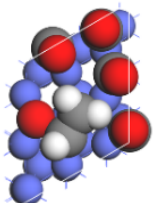

(b)

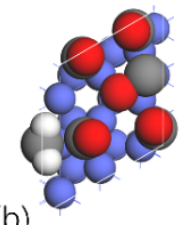

(c)
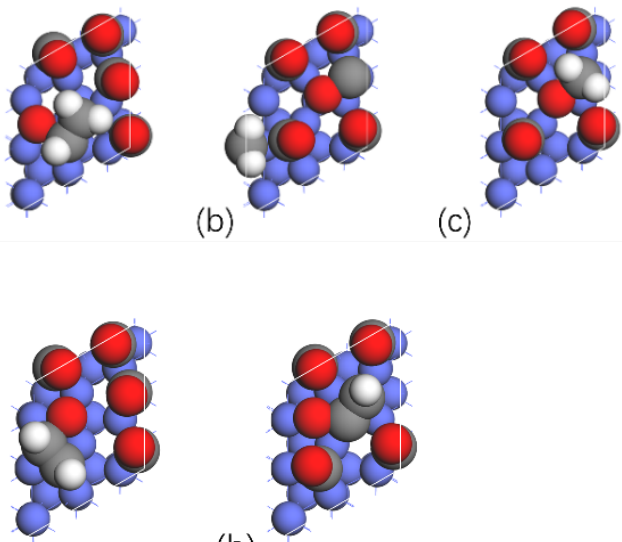

(d)

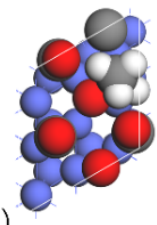

(e)

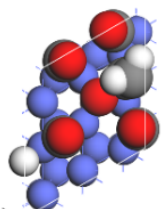

(f)

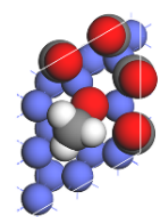

(g)

(h)

Figure S30. Top views of the calculated transition state geometries of $\mathrm{CH}_{\mathrm{x}} \mathrm{CH}_{\mathrm{y}} \mathrm{O}$ dissociation reactions on $\mathrm{Co}(0001)$ in the presence of $4 \mathrm{CO}$. (a) $\mathrm{TS}_{\mathrm{CH}_{2} \mathrm{CHO}\left(\mathrm{CH}_{2} \mathrm{CH}+\mathrm{O}\right)}$; (b) $\mathrm{TS}_{\mathrm{CH}_{2} \mathrm{CO}\left(\mathrm{CH}_{2} \mathrm{C}+\mathrm{O}\right)}$; (c) $\mathrm{TS}_{\mathrm{CH}_{2} \mathrm{O}}$ 
( $\left.\mathrm{CH}_{2}+\mathrm{O}\right) ;(\mathrm{d}) \mathrm{TS}_{\mathrm{CH}_{3} \mathrm{CHO}\left(\mathrm{CH}_{3} \mathrm{CH}+\mathrm{O}\right)} ;(\mathrm{e}) \mathrm{TS}_{\mathrm{CH}_{3} \mathrm{CO}\left(\mathrm{CH}_{3} \mathrm{C}+\mathrm{O}\right)} ;$ (f) $\mathrm{TS}_{\mathrm{CH}_{3} \mathrm{O}\left(\mathrm{CH}^{3}+\mathrm{O}\right)} ;(\mathrm{g}) \mathrm{TS}_{\mathrm{CHCHO}(\mathrm{CHCH}+\mathrm{O})}$; and (h) $\mathrm{TS}_{\mathrm{CHCO}}$ $(\mathrm{CHC}+\mathrm{O})$.

\subsection{0 $\mathrm{C}_{1}$ and $\mathrm{CHO}$ coupling reactions in the presence of $4 \mathrm{CO}$}

(a)

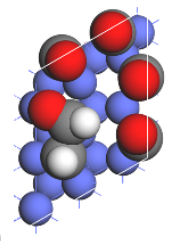

(b)

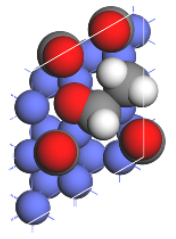

Figure S31: Top views of the calculated transition state geometries of $\mathrm{C}_{1}$ and $\mathrm{CHO}$ coupling reactions in the presence of $4 \mathrm{CO}$ on $\mathrm{Co}(0001)$. (a) $\mathrm{TS}_{\mathrm{CH}+\mathrm{CHO}(\mathrm{CHCHO})}$; and (b) $\mathrm{TS}_{\mathrm{CH}^{2}+\mathrm{CHO}(\mathrm{CH} 2 \mathrm{CHO}) \text {. }}$

\subsubsection{Transition state geometries in the presence of $5 \mathrm{CO}$}

\subsection{Direct $\mathrm{CO}$ dissociation and $\mathrm{H}$-assisted $\mathrm{CO}$ dissociation in the presence of $5 \mathrm{CO}$}

(a)

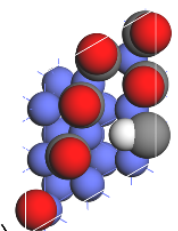

(b)

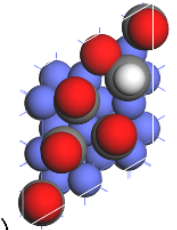

(c)

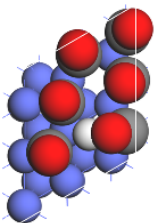

(d)

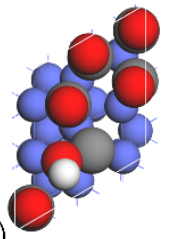

(e)

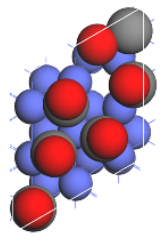

Figure S32. Top views of the calculated transition state geometries of direct CO dissociation and

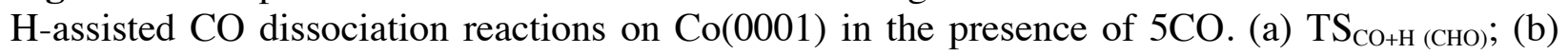
$\mathrm{TS}_{\mathrm{CHO}(\mathrm{CH}+\mathrm{O})}$; (c) $\mathrm{TS}_{\mathrm{CO}+\mathrm{H}(\mathrm{COH})}$; (d) $\mathrm{TS}_{\mathrm{COH}(\mathrm{C}+\mathrm{OH})}$; and (e) $\mathrm{TS}_{\mathrm{CO}(\mathrm{C}+\mathrm{O})}$.

\subsection{Water formation in the presence of $5 \mathrm{CO}$}

(a)

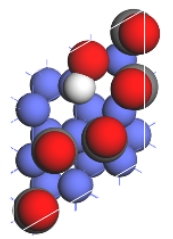

(b)

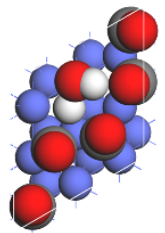

(c)

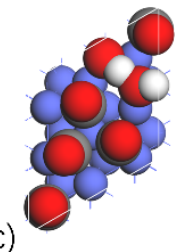

Figure S33. Top views of the calculated transition state geometries of water formation on the flat

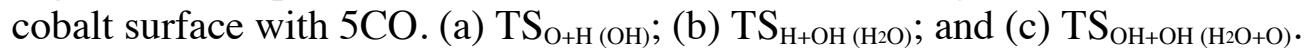




\subsubsection{3 $\mathrm{C}_{1}$ Hydrogenation to Methane in the presence of $5 \mathrm{CO}$}

(a)

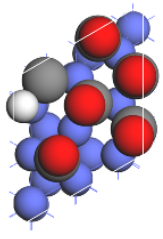

(b)

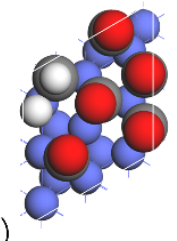

(c)

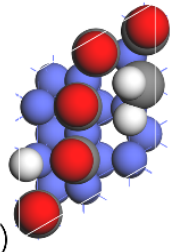

(d)

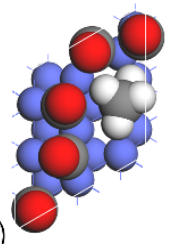

Figure S34. Top views of the calculated transition state geometries of $\mathrm{C}_{1}$ hydrogenation to methane on $\mathrm{Co}(0001)$ in the presence of $5 \mathrm{CO}$. (a) $\mathrm{TS}_{\mathrm{C}+\mathrm{H}(\mathrm{CH})}$; (b) $\mathrm{TS}_{\mathrm{CH}+\mathrm{H}\left(\mathrm{CH}_{2}\right)}$; (c) $\mathrm{TS}_{\mathrm{CH}^{2}+\mathrm{H}\left(\mathrm{CH}_{3}\right)}$; and (d) $\mathrm{TS}_{\mathrm{CH}^{3}+\mathrm{H}}$ $(\mathrm{CH} 4)$.

\subsubsection{4 $\mathrm{C}_{1}+\mathrm{C}_{1}$ coupling reactions in the presence of $5 \mathrm{CO}$}

(a)

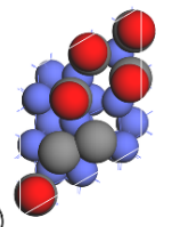

(b)

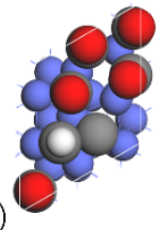

(g)

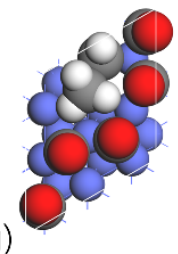

(h)

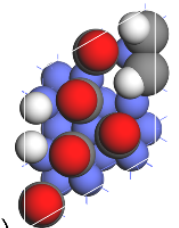

(c)

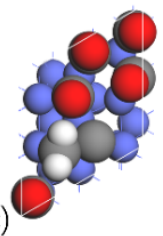

(d)

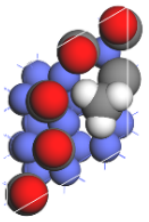

(e)

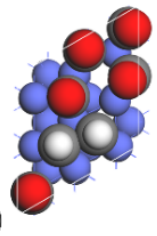

(f)

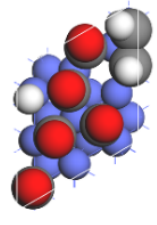

(i)

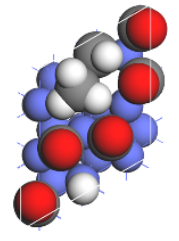

Figure S35. Top views of the calculated transition state geometries of $\mathrm{C}_{1}+\mathrm{C}_{1}$ coupling reactions on $\mathrm{Co}\left(0001\right.$ ) in the presence of $4 \mathrm{CO}$. (a) $\mathrm{TS}_{\mathrm{C}+\mathrm{C}}$; (b) $\mathrm{TS}_{\mathrm{C}+\mathrm{CH}}$; (c) $\mathrm{TS}_{\mathrm{C}+\mathrm{CH} 2}$; (d) $\mathrm{TS}_{\mathrm{C}+\mathrm{CH} 3}$; (e) $\mathrm{TS}_{\mathrm{CH}+\mathrm{CH}}$; (f) $\mathrm{TS}_{\mathrm{CH}+\mathrm{CH} 2} ;$ (g) $\mathrm{TS}_{\mathrm{CH}+\mathrm{CH} 3}$; (h) $\mathrm{TS}_{\mathrm{CH}^{2}+\mathrm{CH}_{2}}$; (i) $\mathrm{TS}_{\mathrm{CH}^{2}+\mathrm{CH} 3}$. 


\subsubsection{5 $\mathrm{C}_{2}$ hydrogenation reactions in the presence of $5 \mathrm{CO}$}

(a)

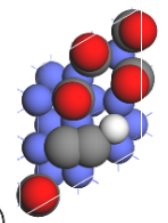

(g)

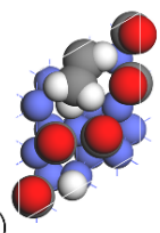

(b)

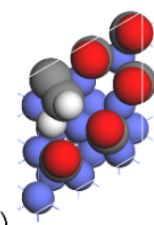

(h)

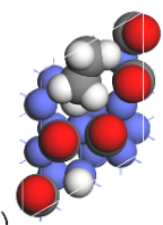

(c)

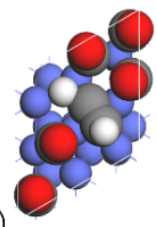

(i)

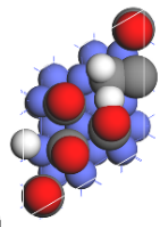

(d)

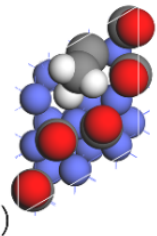

(j)

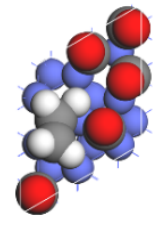

(e)

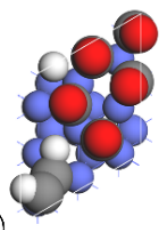

(k)

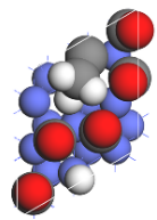

(f)

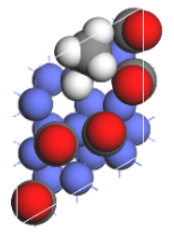

(l)

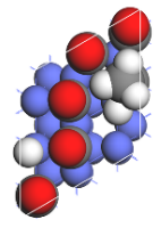

Figure S36: Top views of the calculated transition state geometries of $\mathrm{C}_{2}$ hydrogenations on $\mathrm{Co}(0001)$ in the presence of $5 \mathrm{CO}$. (a) $\mathrm{TS}_{\mathrm{CC}+\mathrm{H}(\mathrm{CCH})}$; (b) $\mathrm{TS}_{\mathrm{CCH}+\mathrm{H}\left(\mathrm{CCH}_{2}\right)}$; (c) $\mathrm{TS}_{\mathrm{CCH}+\mathrm{H}(\mathrm{CHCH})}$; (d) $\mathrm{TS}_{\mathrm{CCH}+\mathrm{H}}$ ( $\left.\mathrm{CCH}_{3}\right)$; (e) $\mathrm{TS}_{\mathrm{CCH}_{2}+\mathrm{H}\left(\mathrm{CHCH}_{2}\right)}$; (f) $\mathrm{TS}_{\mathrm{CCH}_{3}+\mathrm{H}\left(\mathrm{CHCH}_{3}\right)}$; (g) $\mathrm{TS}_{\mathrm{CH}_{2} \mathrm{CH}_{2}+\mathrm{H}\left(\mathrm{CH}_{2} \mathrm{CH}_{3}\right)}$; (h) $\mathrm{TS}_{\mathrm{CH}_{2} \mathrm{CH}_{3}+\mathrm{H}\left(\mathrm{CH}_{3} \mathrm{CH}_{3}\right)}$; (i) $\mathrm{TS}_{\mathrm{CHCH}+\mathrm{H}}$ ( $\left.\mathrm{CHCH}_{2}\right)$; (j) $\mathrm{TS}_{\mathrm{CHCH}^{2}+\mathrm{H}\left(\mathrm{CH}_{2} \mathrm{CH}_{2}\right)}$; (k) $\mathrm{TS}_{\mathrm{CHCH}^{2}+\mathrm{H}\left(\mathrm{CHCH}_{3}\right)}$; and (l) $\mathrm{TS}_{\mathrm{CHCH}^{3}+\mathrm{H}\left(\mathrm{CH}_{2} \mathrm{CH}_{3}\right)}$.

\subsubsection{6 $\mathrm{CO}$ and $\mathrm{C}_{1}$ coupling reactions in the presence of $5 \mathrm{CO}$}

(a)

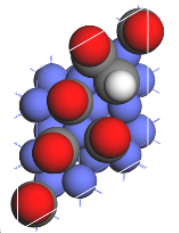

(b)

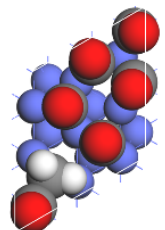

(c)

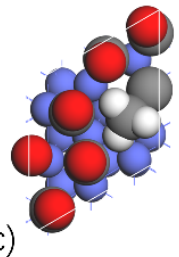

Figure S37. Top views of the calculated transition state geometries of $\mathrm{CO}$ and $\mathrm{C}_{1}$ coupling reactions in the presence of $5 \mathrm{CO}$ on $\mathrm{Co}(0001)$. (a) $\mathrm{TS}_{\mathrm{CH}+\mathrm{CO}(\mathrm{CHCO})}$; (b) $\mathrm{TS}_{\mathrm{CH}^{2}+\mathrm{CO}\left(\mathrm{CH}_{2} \mathrm{CO}\right)}$; and (c) $\mathrm{TS}_{\mathrm{CH} 3+\mathrm{CO}(\mathrm{CH} 3 \mathrm{CO}) \text {. }}$

\subsubsection{7 $\mathrm{C}_{1}$ and $\mathrm{OH}$ coupling reactions in the presence of $5 \mathrm{CO}$}

(a)

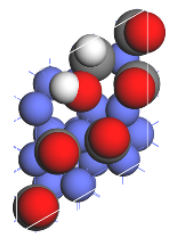

(b)

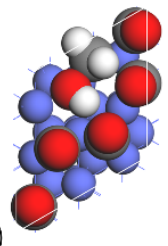

(c)

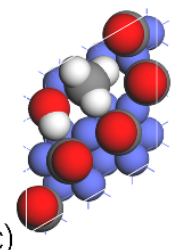

Figure S38: Top views of the calculated transition state geometries of $\mathrm{C}_{1}$ and $\mathrm{OH}$ coupling reactions in the presence of $5 \mathrm{CO}$ on $\mathrm{Co}(0001)$. (a) $\mathrm{TS}_{\mathrm{CH}-\mathrm{OH}(\mathrm{CH}+\mathrm{OH})}$; (b) $\mathrm{TS}_{\mathrm{CH}_{2}-\mathrm{OH}\left(\mathrm{CH}_{2}+\mathrm{OH}\right)}$; and (c) $\mathrm{TS}_{\mathrm{CH} 3+\mathrm{OH}(\mathrm{CH} 3 \mathrm{OH})}$. 


\subsubsection{8 $\mathrm{CH}_{x} \mathrm{CH}_{y} \mathrm{O}$ hydrogenations in the presence of $5 \mathrm{CO}$}

(a)

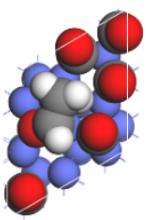

(b)
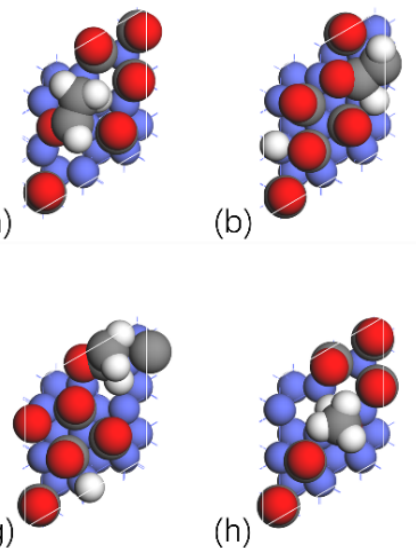

(h)

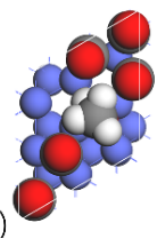

(c)

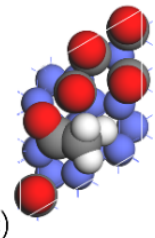

(i)

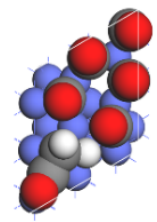

(d)

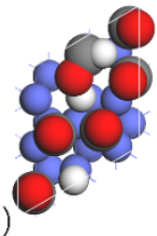

(j)

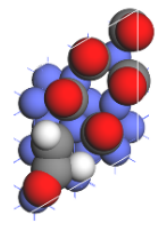

(e)

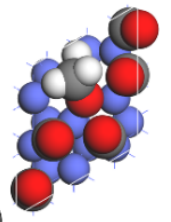

(k)

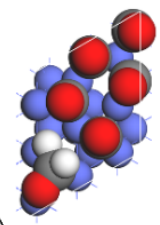

(f)

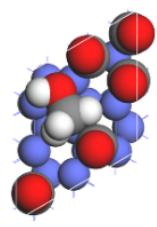

(l)

(n)

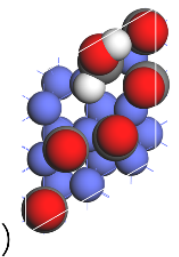

(m)

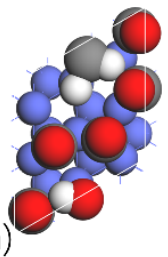

Figure S39. Top views of the calculated transition state geometries of $\mathrm{CH}_{x} \mathrm{CH}_{y} \mathrm{O}$ hydrogenations

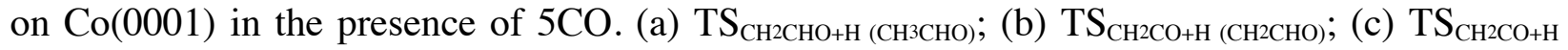

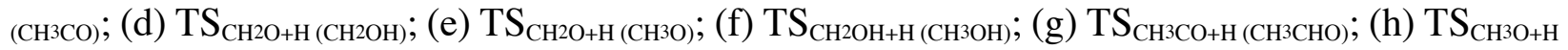
(Снзон); (i) $\mathrm{TS}_{\mathrm{CHCO}+\mathrm{H}(\mathrm{CH} 2 \mathrm{CO})}$; (j) $\mathrm{TS}_{\mathrm{CHCO}+\mathrm{H}(\mathrm{CHCHO})}$; (k) $\mathrm{TS}_{\mathrm{CHO}+\mathrm{H}(\mathrm{CH} 2 \mathrm{O})}$; (l) $\mathrm{TS}_{\mathrm{CHO}+\mathrm{H}(\mathrm{CHOH})}$; (m) $\mathrm{TS}_{\mathrm{CHOH}+\mathrm{H}}$ (Сн2О); ; and (n) $\mathrm{TS}_{\mathrm{COH}+\mathrm{H}(\mathrm{CHOH})}$.

\subsubsection{9 $\mathrm{CH}_{x} \mathrm{CH}_{y} \mathrm{O}$ dissociation in the presence of $5 \mathrm{CO}$}

(a)
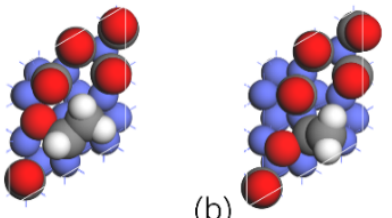

(b)

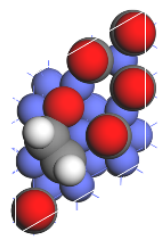

(c)

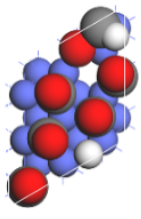

(d)

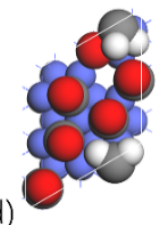

(e)

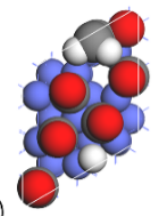

(f)

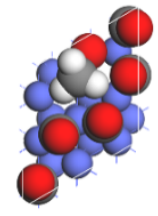

(h)

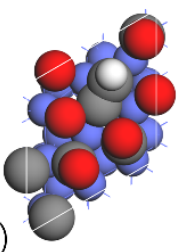

Figure S40. Top views of the calculated transition state geometries of $\mathrm{CH}_{\mathrm{x}} \mathrm{CH}_{\mathrm{y}} \mathrm{O}$ dissociation

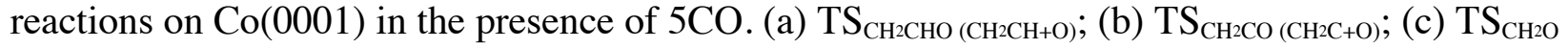


( $\left.\mathrm{CH}_{2}+\mathrm{O}\right) ;(\mathrm{d}) \mathrm{TS}_{\mathrm{CH}_{3} \mathrm{CHO}\left(\mathrm{CH}_{3} \mathrm{CH}+\mathrm{O}\right)} ;(\mathrm{e}) \mathrm{TS}_{\mathrm{CH}_{3} \mathrm{CO}\left(\mathrm{CH}_{3} \mathrm{C}+\mathrm{O}\right)} ;(\mathrm{f}) \mathrm{TS}_{\mathrm{CH}_{3} \mathrm{O}\left(\mathrm{CH}^{3}+\mathrm{O}\right)} ;(\mathrm{g}) \mathrm{TS}_{\mathrm{CHCHO}(\mathrm{CHCH}+\mathrm{O})}$; and (h) $\mathrm{TS}_{\mathrm{CHCO}}$ $(\mathrm{CHC}+\mathrm{O})$.

\subsection{0 $\mathrm{C}_{1}$ and $\mathrm{CHO}$ coupling reactions in the presence of $5 \mathrm{CO}$}

(a)

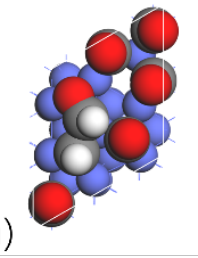

(b)

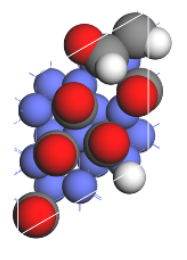

Figure S41. Top views of the calculated transition state geometries of $\mathrm{C}_{1}$ and $\mathrm{CHO}$ coupling

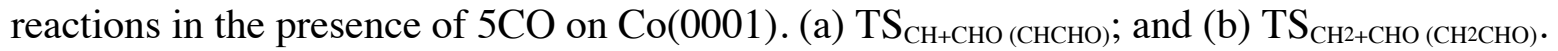

\section{References}

(1) Medford, A. J.; Shi, C.; Hoffmann, M. J.; Lausche, A. C.; Fitzgibbon, S. R.; Bligaard, T.; Norskov, J. K. CatMAP: A Software Package for Descriptor-Based Microkinetic Mapping of Catalytic Trends. Catal. Lett. 2015, 145, 794-807.

(2) Gong, X. Q.; Raval, R.; Hu, P. CO dissociation and O removal on Co(0001): a density functional theory study. Surf. Sci. 2004, 562, 247-256.

(3) Ciobica, I. M.; van Santen, R. A. Carbon Monoxide Dissociation on Planar and Stepped $\mathrm{Ru}(0001)$ Surfaces. J. Phys. Chem. B 2003, 107, 3808-3812.

(4) Shetty, S.; van Santen, R. A. CO dissociation on Ru and Co surfaces: The initial step in the Fischer-Tropsch synthesis. Catal. Today 2011, 171, 168-173.

(5) Ojeda, M.; Nabar, R.; Nilekar, A. U.; Ishikawa, A.; Mavrikakis, M.; Iglesia, E. CO activation pathways and the mechanism of Fischer-Tropsch synthesis. J. Catal. 2010, 272, 287297.

(6) Zhang, R. G.; Liu, F.; Wang, Q.; Wang, B. J.; Li, D. B. Insight into CHx formation in Fischer-Tropsch synthesis on the hexahedron Co catalyst: Effect of surface structure on the preferential mechanism and existence form. Appl. Catal., A 2016, 525, 76-84.

(7) Filot, I. A. W.; van Santen, R. A.; Hensen, E. J. M. Quantum chemistry of the FischerTropsch reaction catalysed by a stepped ruthenium surface. Catal. Sci. Technol. 2014, 4, 31293140 .

(8) Filot, I. A. W.; Broos, R. J. P.; van Rijn, J. P. M.; van Heugten, G. J. H. A.; van Santen, R. A.; Hensen, E. J. M. First-Principles-Based Microkinetics Simulations of Synthesis Gas Conversion on a Stepped Rhodium Surface. ACS Catal. 2015, 5, 5453-5467.

(9) Michaelides, A.; Hu, P. Catalytic Water Formation on Platinum: A First-Principles Study. J. Am. Chem. Soc. 2001, 123, 4235-4242.

(10) Cheng, J.; Gong, X. Q.; Hu, P.; Lok, C. M.; Ellis, P.; French, S. A quantitative determination of reaction mechanisms from density functional theory calculations: Fischer-Tropsch synthesis on flat and stepped cobalt surfaces. J. Catal. 2008, 254, 285-295. 
(11) Wang, Z. J.; Yan, Z.; Liu, C. J.; Goodman, D. W. Surface Science Studies on Cobalt Fischer-Tropsch Catalysts. Chemcatchem 2011, 3, 551-559.

(12) Cheng, J.; Hu, P.; Ellis, P.; French, S.; Kelly, G.; Lok, C. M. A DFT study of the chain growth probability in Fischer-Tropsch synthesis. J. Catal. 2008, 257, 221-228.

(13) Cheng, J.; Hu, P.; Ellis, P.; French, S.; Kelly, G.; Lok, C. M. A First-Principles Study of Oxygenates on Co Surfaces in Fischer-Tropsch Synthesis. J. Phys. Chem. C 2008, 112, 9464-9473.

(14) Inderwildi, O. R.; King, D. A.; Jenkins, S. J. Fischer-Tropsch synthesis of liquid fuels: learning lessons from homogeneous catalysis. Physical chemistry chemical physics : PCCP 2009, $11,11110-11112$.

(15) Zhuo, M. K.; Borgna, A.; Saeys, M. Effect of the CO coverage on the Fischer-Tropsch synthesis mechanism on cobalt catalysts. J. Catal. 2013, 297, 217-226.

(16) Zhuo, M. K.; Tan, K. F.; Borgna, A.; Saeys, M. Density Functional Theory Study of the CO Insertion Mechanism for Fischer-Tropsch Synthesis over Co Catalysts. J. Phys. Chem. C 2009, $113,8357-8365$.

(17) Eckle, S.; Anfang, H.-G.; Behm, R. J. r. Reaction Intermediates and Side Products in the Methanation of $\mathrm{CO}$ and CO2over Supported Ru Catalysts in H2-Rich Reformate Gases. J. Phys. Chem. C 2011, 115, 1361-1367.

(18) Zhao, Y. H.; Sun, K.; Ma, X.; Liu, J.; Sun, D.; Su, H. Y.; Li, W. X. Carbon chain growth by formyl insertion on rhodium and cobalt catalysts in syngas conversion. Angew. Chem.Int.Ed.2011, $50,5335-5338$.

(19) Moazami, N.; Wyszynski, M. L.; Mahmoudi, H.; Tsolakis, A.; Zou, Z.; Panahifar, P.; Rahbar, K. Modelling of a fixed bed reactor for Fischer-Tropsch synthesis of simulated N2-rich syngas over $\mathrm{Co} / \mathrm{SiO} 2$ : Hydrocarbon production. Fuel 2015, 154, 140-151.

(20) Azadi, P.; Brownbridge, G.; Kemp, I.; Mosbach, S.; Dennis, J. S.; Kraft, M. Microkinetic Modeling of the Fischer-Tropsch Synthesis over Cobalt Catalysts. ChemCatChem 2015, 7, 137143.

(21) Lahtinen, J.; Vaari, J.; Kauraala, K. Adsorption and structure dependent desorption of CO on Co(0001). Surf. Sci. 1998, 418, 502-510.

(22) Alavi, A.; Hu, P.; Deutsch, T.; Silvestrelli, P. L.; Hutter, J. CO Oxidation on Pt(111): AnAb InitioDensity Functional Theory Study. Phys. Rev. Lett. 1998, 80, 3650-3653.

(23) Liu, Z.-P.; Hu, P. General Rules for Predicting Where a Catalytic Reaction Should Occur on Metal Surfaces: A Density Functional Theory Study of C-H and C-O Bond Breaking/Making on Flat, Stepped, and Kinked Metal Surfaces. J. Am. Chem. Soc. 2003, 125, 1958-1967.

(24) Michaelides, A.; Liu, Z. P.; Zhang, C. J.; Alavi, A.; King, D. A.; Hu, P. Identification of General Linear Relationships between Activation Energies and Enthalpy Changes for Dissociation Reactions at Surfaces. J. Am. Chem. Soc. 2003, 125, 3704-3705. 